Prepared in cooperation with the

Connecticut Department of Energy and Environmental Protection

\title{
Estimated Nitrogen Loads from Selected Tributaries in Connecticut Draining to Long Island Sound, 1999-2009
}

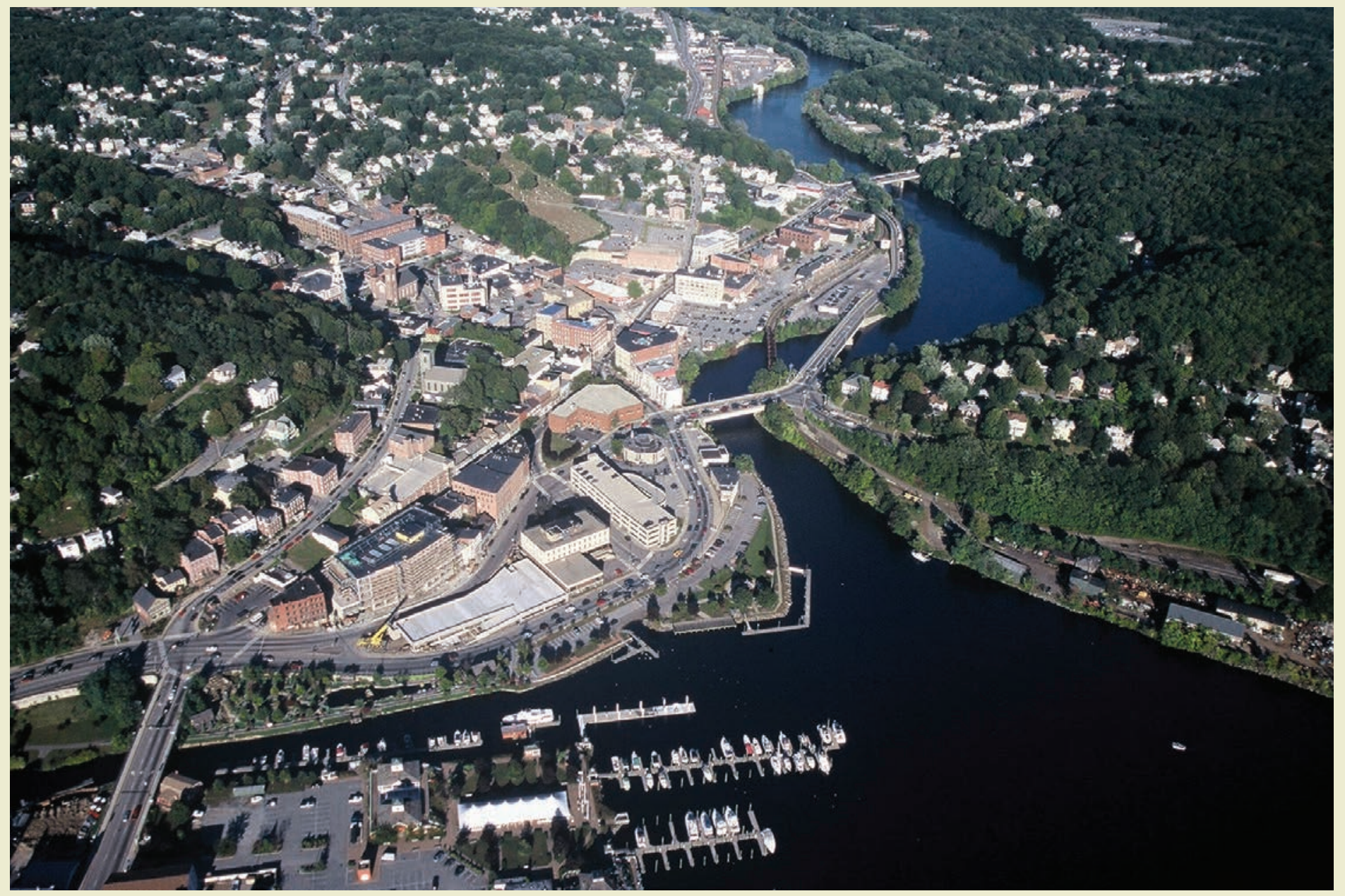

Scientific Investigations Report 2013-5171 
Cover. Photograph of the junction of the Yantic and Shetucket Rivers, where they combine to make the Thames River Estuary, Norwich, Connecticut. Courtesy of the Office of Long Island Sound Programs (OLISP), Bureau of Water Protection and Land Reuse, Connecticut Department of Energy and Environmental Protection (CT DEEP). 


\section{Estimated Nitrogen Loads from Selected Tributaries in Connecticut Draining to Long Island Sound, 1999-2009}

By John R. Mullaney and Gregory E. Schwarz

Prepared in cooperation with the Connecticut Department of Energy and Environmental Protection

Scientific Investigations Report 2013-5171 


\title{
U.S. Department of the Interior SALLY JEWELL, Secretary
}

\section{U.S. Geological Survey Suzette M. Kimball, Acting Director}

\author{
U.S. Geological Survey, Reston, Virginia: 2013
}

For more information on the USGS - the Federal source for science about the Earth, its natural and living resources, natural hazards, and the environment, visit http://www.usgs.gov or call 1-888-ASK-USGS.

For an overview of USGS information products, including maps, imagery, and publications, visit http://www.usgs.gov/pubprod

To order this and other USGS information products, visit http://store.usgs.gov

Any use of trade, firm, or product names is for descriptive purposes only and does not imply endorsement by the U.S. Government.

Although this information product, for the most part, is in the public domain, it also may contain copyrighted materials as noted in the text. Permission to reproduce copyrighted items must be secured from the copyright owner.

Suggested citation:

Mullaney, J.R., and Schwarz, G.E., 2013, Estimated nitrogen loads from selected tributaries in Connecticut draining to Long Island Sound, 1999-2009: U.S. Geological Survey Scientific Investigations Report 2013-5171, 65 p., http://dx.doi.org/10.3133/sir20135171/.

ISSN 2328-0328 (online) 


\section{Acknowledgments}

The authors would like to acknowledge Paul Stacey, Kelly Streich, and Mark Parker of the Connecticut Department of Energy and Environmental Protection and Joseph Salata of the U.S. Environmental Protection Agency for providing data and personal knowledge about Long Island Sound that assisted in this project. We would like to thank U.S. Geological Survey personnel Timothy Frick and Guy Holzer for their dedicated sampling and data-collection efforts, Jonathan Morrison for technical assistance, Nicholas Dosch for sampling and data analysis, Thomas Trombley for data analysis and GIS assistance, and Marc Zimmerman and David Holtschlag for technical reviews. 
This page has been left blank intentionally. 


\section{Contents}

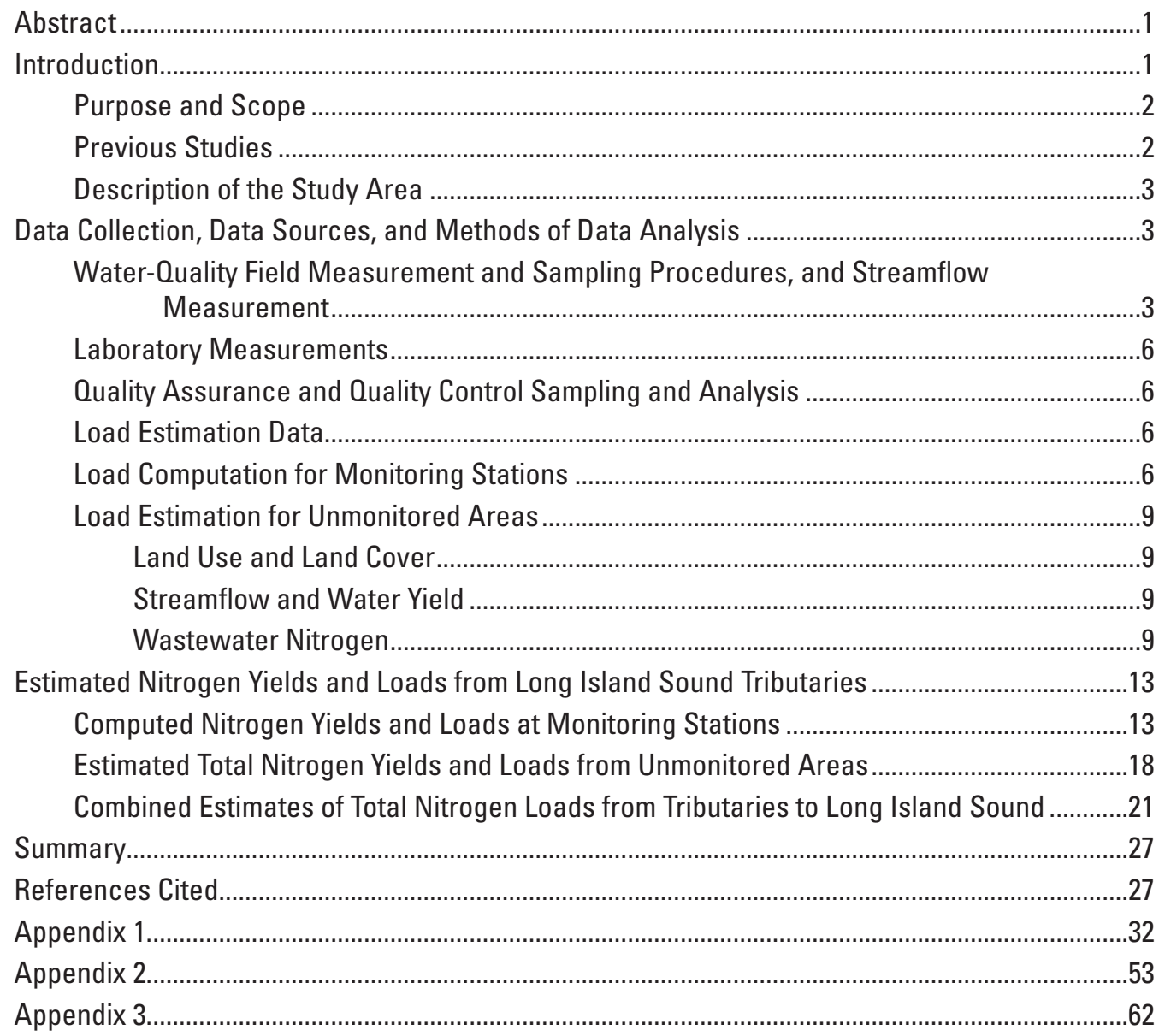

\section{Figures}

1. Map showing the Long Island Sound watershed in the northeastern United States, with land cover and selected water-quality monitoring stations on rivers draining to Long Island Sound, northeastern United States.

2. Map showing unmonitored areas draining to Long Island Sound, water-quality monitoring stations, and surrogate streamgages in parts of Connecticut, Rhode Island, Massachusetts, and New York.

3. Graph showing runoff in Connecticut, water years 1980-2011, and median runoff, water years $1980-2009$.

4. Graph showing loads of nitrogen discharged from Connecticut wastewater-treatment facilities in monitored and unmonitored basins draining to Long Island Sound, calendar years 1999-2002 and water years 2003-09

5. Boxplots showing the distribution of computed annual total nitrogen yields from selected water-quality monitoring stations in basins draining to Long Island Sound, water years $1999-2009$. 
6. Graph showing median annual total nitrogen yields for water years 1988-98 in relation to those for water years 1999-2009 for basins draining to Long Island Sound 18

7. Graph showing transformed computed total nitrogen yield in relation to transformed estimated total nitrogen yield from monitored basins draining to Long Island Sound, water years 1999-2009.

8. Graph showing transformed residuals, by station in basins draining to Long Island Sound, water years 1999-2009.

9. Graph showing transformed residuals, by water year, for monitored basins draining to Long Island Sound, water years 1999-2009

10. Boxplots showing distribution of estimated annual total nitrogen yield for unmonitored basins draining to Long Island Sound

11. Graph showing computed or estimated nitrogen yields and confidence intervals for monitored and unmonitored basins draining to Long Island Sound, water year 2009....23

12. Graphs showing Long Island Sound management zones for nitrogen and estimated loads from monitored and unmonitored areas draining to Long Island Sound, water years 1999-2009.

13. Graph showing estimated total nitrogen loads for monitored and unmonitored areas draining to Long Island Sound, water years 1999-2009.

\section{Tables}

1. Water-quality monitoring stations used for nitrogen load analysis in basins draining to Long Island Sound.

1. Water-quality monitoring stations used for nitrogen load analysis in basins draining to Long Island Sound.

2. Unmonitored areas draining to Long Island Sound, Connecticut and Rhode Island ......10

3. Surrogate streamgages selected to represent unmonitored basins that drain to Long Island Sound...

4. Estimated cumulative nitrogen loads from wastewater-treatment facilities outside Connecticut for stations in the drainage area to Long Island Sound...

5. Summary statistics for total nitrogen loads and yields from selected water-quality stations draining to Long Island Sound.

5. Summary statistics for total nitrogen loads and yields from selected water-quality stations draining to Long Island Sound.

5. Summary statistics for total nitrogen loads and yields from selected water-quality stations draining to Long Island Sound.

6. Generalized least squares (GLS) estimates of model coefficients and standard errors, with asymptotically valid t-statistics and p-values

7. Estimated total nitrogen loads from monitored basins and unmonitored areas in Long Island Sound nitrogen management zones, water years 1999-2009

8. Computed nitrogen loads for state-border monitoring stations and percent of nitrogen load contributed to the Long Island Sound management zones, water years 1999-2009. 


\section{Conversion Factors and Datum}

\begin{tabular}{|c|c|c|}
\hline Multiply & By & To obtain \\
\hline \multicolumn{3}{|c|}{ Length } \\
\hline foot $(\mathrm{ft})$ & 0.3048 & meter $(\mathrm{m})$ \\
\hline \multicolumn{3}{|c|}{ Area } \\
\hline square mile $\left(\mathrm{mi}^{2}\right)$ & 259.0 & hectare (ha) \\
\hline square mile $\left(\mathrm{mi}^{2}\right)$ & 2.590 & square kilometer $\left(\mathrm{km}^{2}\right)$ \\
\hline \multicolumn{3}{|c|}{ Volume } \\
\hline million gallons (Mgal) & 3,785 & cubic meter $\left(\mathrm{m}^{3}\right)$ \\
\hline cubic foot $\left(\mathrm{ft}^{3}\right)$ & 0.02832 & cubic meter $\left(\mathrm{m}^{3}\right)$ \\
\hline \multicolumn{3}{|c|}{ Flow rate } \\
\hline cubic foot per second $\left(\mathrm{ft}^{3} / \mathrm{s}\right)$ & 0.02832 & cubic meter per second $\left(\mathrm{m}^{3} / \mathrm{s}\right)$ \\
\hline $\begin{array}{l}\text { cubic foot per second per square mile } \\
{\left[\left(\mathrm{ft}^{3} / \mathrm{s}\right) / \mathrm{mi}^{2}\right]}\end{array}$ & 0.01093 & $\begin{array}{l}\text { cubic meter per second per square } \\
\text { kilometer }\left[\left(\mathrm{m}^{3} / \mathrm{s}\right) / \mathrm{km}^{2}\right]\end{array}$ \\
\hline million gallons per day (Mgal/d) & 0.04381 & cubic meter per second $\left(\mathrm{m}^{3} / \mathrm{s}\right)$ \\
\hline \multicolumn{3}{|c|}{ Mass } \\
\hline $\begin{array}{l}\text { pounds per square mile per year } \\
{\left[\left(\left(\mathrm{lb} / \mathrm{mi}^{2}\right) / \mathrm{yr}\right]\right.}\end{array}$ & 0.001751 & kilogram per hectare per year $[(\mathrm{kg} / \mathrm{ha}) / \mathrm{yr}]$ \\
\hline
\end{tabular}

\section{Abbreviations}

$\begin{array}{ll}\text { AMLE } & \text { Adjusted Maximum Likelihood Estimation } \\ \text { CCMP } & \text { Comprehensive Conservation and Management Plan } \\ \text { CTDEEP } & \text { Connecticut Department of Energy and Environmental Protection } \\ \text { GLS } & \text { Generalized Least Squares } \\ \text { LISS } & \text { Long Island Sound Study } \\ \text { LOADEST } & \text { load estimator } \\ \text { MLE } & \text { Maximum Likelihood Estimation } \\ \text { NCE } & \text { Nitrogen Credit Exchange } \\ \text { NLCD } & \text { National Land Cover Data } \\ \text { NWIS } & \text { National Water Information System } \\ \text { NWOL } & \text { National Water Quality Laboratory } \\ \text { OLS } & \text { ordinary least squares } \\ \text { OA/OC } & \text { Quality Assurance and quality control } \\ \text { SPARROW } & \text { SPAtially Referenced Regressions on Watershed attributes } \\ \text { TMDL } & \text { Total maximum daily load } \\ \text { USEPA } & \text { U.S. Environmental Protection Agency } \\ \text { WWTF } & \text { wastewater-treatment facility }\end{array}$


This page has been left blank intentionally. 


\title{
Estimated Nitrogen Loads from Selected Tributaries in Connecticut Draining to Long Island Sound 1999-2009
}

\author{
By John R. Mullaney and Gregory E. Schwarz
}

\section{Abstract}

The total nitrogen load to Long Island Sound from Connecticut and contributing areas to the north was estimated for October 1998 to September 2009. Discrete measurements of total nitrogen concentrations and continuous flow data from 37 water-quality monitoring stations in the Long Island Sound watershed were used to compute total annual nitrogen yields and loads. Total annual computed yields and basin characteristics were used to develop a generalizedleast squares regression model for use in estimating the total nitrogen yields from unmonitored areas in coastal and central Connecticut. Significant variables in the regression included the percentage of developed land, percentage of row crops, point-source nitrogen yields from wastewater-treatment facilities, and annual mean streamflow.

Computed annual median total nitrogen yields at individual monitoring stations ranged from less than 2,000 pounds per square mile in mostly forested basins (typically less than 10 percent developed land) to more than 13,000 pounds per square mile in urban basins (greater than 40 percent developed) with wastewater-treatment facilities and in one agricultural basin. Medians of computed total annual nitrogen yields for water years 1999-2009 at most stations were similar to those previously computed for water years 1988-98. However, computed medians of annual yields at several stations, including the Naugatuck River, Quinnipiac River, and Hockanum River, were lower than during 1988-98. Nitrogen yields estimated for 26 unmonitored areas downstream from monitoring stations ranged from less than 2,000 pounds per square mile to 34,000 pounds per square mile.

Computed annual total nitrogen loads at the farthest downstream monitoring stations were combined with the corresponding estimates for the downstream unmonitored areas for a combined estimate of the total nitrogen load from the entire study area. Resulting combined total nitrogen loads ranged from 38 to 68 million pounds per year during water years 1999-2009. Total annual loads from the monitored basins represent 63 to 74 percent of the total load. Computed annual nitrogen loads from four stations near the Massachusetts border with Connecticut represent
52 to 54 percent of the total nitrogen load during water years 2008-9, the only years with data for all the border sites.

During the latter part of the 1999-2009 study period, total nitrogen loads to Long Island Sound from the study area appeared to increase slightly. The apparent increase in loads may be due to higher than normal streamflows, which consequently increased nonpoint nitrogen loads during the study, offsetting major reductions of nitrogen from wastewater-treatment facilities. Nitrogen loads from wastewater treatment facilities declined as much as 2.3 million pounds per year in areas of Connecticut upstream from the monitoring stations and as much as 5.8 million pounds per year in unmonitored areas downstream in coastal and central Connecticut.

\section{Introduction}

The Long Island Sound Study (LISS) began in 1985 when Congress appropriated funds for the U.S. Environmental Protection Agency (USEPA) to carry out a program to research, monitor, and assess the water quality of Long Island Sound in concert with the States of Connecticut and New York, forming a bi-State partnership consisting of Federal and State agencies, user groups, concerned organizations, and individuals dedicated to restoring and protecting the Sound (New York Department of Environmental Conservation and Connecticut Department of Environmental Protection, 2000). In 1994, the LISS completed a comprehensive conservation and management plan (CCMP) that identified six problems that merit special attention, including low dissolved oxygen (hypoxia), toxic contamination, pathogen contamination, effects of habitat loss on the health of living resources, land use and development resulting in habitat loss, and degradation of water quality (Long Island Sound Study, 1994). In 2012, an effort to update the CCMP was begun.

Hypoxia is the issue identified as the highest priority water-quality problem for Long Island Sound. Hypoxia is defined by the LISS as concentrations of dissolved oxygen of 3 milligrams per liter $(\mathrm{mg} / \mathrm{L})$ or less in a water column of Long Island Sound (Long Island Sound Study, 1994). The problem occurs during the summer months in the bottom waters of western Long Island Sound. 
Hypoxia is believed to be caused by overenrichment of nitrogen in Long Island Sound. Although nitrogen is essential to a productive ecosystem, too much nitrogen fuels the excessive growth of algae. When the algae die, they sink to the bottom, where they are consumed by bacteria. The microbial decay of algae and the respiration of oxygenbreathing organisms use up the available oxygen in the lower water column and in the bottom sediments, gradually reducing the dissolved oxygen concentration to unhealthy levels. If the water column remains stratified for an extended period and the amount of organic carbon (primarily from decaying algae) is high enough, oxygen may fall to hypoxic or even anoxic levels. Under these conditions, some organisms may suffocate and die, while others flee the hypoxic area. Dense algal blooms also can inhibit light penetration, preventing sufficient light from reaching the bottom in shallow areas to support the growth of submerged aquatic vegetation, an important habitat for shellfish and juvenile fish. Consequently, excessive nitrogen impairs the function and health of Long Island Sound.

The LISS estimated that the load of nitrogen delivered to Long Island Sound has more than doubled since precolonial times. Discharges from sewage-treatment plants, atmospheric deposition, and runoff are the primary sources of nitrogen enrichment to Long Island Sound (New York Department of Environmental Conservation and Connecticut Department of Environmental Protection, 2000).

In 2001, the States of New York and Connecticut implemented a total maximum daily load (TMDL) with the goal of reducing the nitrogen load to Long Island Sound by 58.5 percent by 2014 (New York Department of Environmental Conservation and Connecticut Department of Environmental Protection, 2000). The goals of the TMDL are to be achieved by reducing nitrogen loads from wastewatertreatment facilities (WWTFs) and nonpoint sources of nitrogen. In Connecticut, waste-load allocations of nitrogen have been assigned to 79 wastewater-treatment facilities (Connecticut Department of Environmental Protection, 2010). Facilities that are under their waste-load allocations can sell nitrogen credits through the nitrogen credit exchange in Connecticut to facilities that exceed their waste-load allocation. Regions of Connecticut have been assigned trading ratios on the basis of their proximity to western Long Island Sound. WWTFs near the western end of Long Island Sound have a trading ratio of 1 , whereas a facility in the northeastern part of Connecticut is assigned a trading ratio of 0.14 on the basis of modeled delivery of nitrogen to the western region of Long Island Sound. For WWTFs with high trading ratios, economics often favor additional treatment through plant upgrades, while those with lower ratios may find the purchase of credits economically advantageous over treatment (Connecticut Department of Environmental Protection, 2010). Upgrades to WWTFs in Connecticut have caused significant reductions in daily nitrogen loads since 2001 (Long Island Sound Study, 2013).
The U.S. Geological Survey (USGS) has collected data on nitrogen in streams in Connecticut since the inception of the Clean Water Act of 1972 and has previously estimated nitrogen loads from rivers draining to Long Island Sound (Trench, 2000; Mullaney and others, 2002). In 2008, the USGS began an enhanced data collection program for the purpose of estimating nutrient loads from tributaries draining to Long Island Sound and to provide data to assist with an update of the nitrogen TMDL, which expires in 2014.

\section{Purpose and Scope}

The purpose of this report is to provide estimates of total nitrogen loads to Long Island Sound from Connecticut and contributing areas to the north from 1998 through 2009 in order to provide information to be used in a revised TMDL for nitrogen loading to Long Island Sound. This report includes load estimates (appendix 1) for total nitrogen at 37 stations in or near Connecticut in the Long Island Sound watershed for water years ${ }^{1} 1999$ to 2009 (October 1998 to September 2009). Samples were collected at 16 fall-line stations - the monitoring stations farthest downstream, yet above tidal influence - and at other upstream basins or basins with a dominant type of land use. These data were used to estimate nitrogen loads from unmonitored areas in coastal Connecticut. For several stations, data collection was begun in October 2008 , and therefore, load estimates were computed only for available years. This report also contains information on total nitrogen yields to enable comparison of the export of nitrogen per unit area among monitoring stations and to be used in a statistical model to estimate nitrogen loads downstream from the fall-line stations. The computed total nitrogen loads for the fall-line stations were summed with the estimated loads from below the fall-line stations to create a combined estimate of the nitrogen loads to Long Island Sound from the study area.

\section{Previous Studies}

This report serves as an extension of the analyses that were done from 1988 through 1998 (Mullaney and others, 2002). The previous analysis was primarily designed to estimate the nonpoint source loads of nitrogen to Long Island Sound from the same study area as in this report, using nearly identical methods. Mullaney and others (2002) identified information and efforts that would be useful for improving nitrogen load estimates to Long Island Sound, including (1) adding additional monitoring stations representative of urban and agricultural land uses, (2) increasing sampling frequency for nitrogen at new or existing stations, (3) adding continuous streamgaging, where possible, to nitrogen monitoring stations to increase the pool of stations for use in

\footnotetext{
${ }^{1} \mathrm{~A}$ water year is the period from October 1 of the previous year through September 30 of the year designated; for example, water year 2009 covers October 1, 2008, through September 30, 2009.
} 
load calculation, (4) developing methods for computing loads in tidal reaches, (5) analyzing newly available temporal data on nitrogen loads from WWTFs in Connecticut to improve regression models used to estimate nitrogen loads from unmonitored areas, (6) developing a water-diversion tracking system to understand the implications of using surrogate streamgages to estimate annual streamflows from unmonitored areas, and (7) applying field scale studies or models to determine instream losses of nitrogen.

A number of these information sources were addressed in this study. Several additional monitoring stations were added, although others were discontinued that had been used from 1988 through 1998. The sampling frequency was increased to 12 times per year at the fall-line stations and at newly established stations. Continuous streamflow measurement was added to the streamgages at Housatonic River near Ashley Falls, Massachusetts (site 30; figs. 1 and 2), and Shetucket River at Taftville, Connecticut (site 4; figs. 1,2). Nitrogen loads computed for 12 monitoring stations from 2003 through 2005 from Deacon and others (2006) were included in this study (fig. 1).

Nitrogen load data from tidal reaches are currently unavailable; however, nitrogen sampling and discharge measurement are being conducted on the lower Connecticut River and likely will be available for future updates on nitrogen loads to Long Island Sound (Jonathan Morrison, U.S. Geological Survey, oral commun., 2013). Data on monthly loads of total nitrogen from WWTFs in Connecticut became available in 2002; the data were used to improve the regression model used to estimate nitrogen loads from unmonitored areas draining to Long Island Sound.

Two studies investigated the attenuation of nitrogen in the study area; one used the Spatially Referenced Regressions on Watershed Attributes (SPARROW) model (Moore and others, 2011), and the other used mass balance and in situ denitrification measurements on two reaches of the Connecticut River in New Hampshire and Massachusetts (Smith and others, 2008).

\section{Description of the Study Area}

The study area (fig. 1) consists of the watershed draining to Long Island Sound from Connecticut, Massachusetts, New Hampshire, Vermont, and small parts of New York (excluding Long Island) and Rhode Island, encompassing more than 16,000 square miles $\left(\mathrm{mi}^{2}\right)$. The major rivers draining the area are the Connecticut, Housatonic, and Thames Rivers. The study area contains about 12 percent urbanized land, 7.7 percent agricultural land, 71 percent forested land, and about 5 percent wetlands, based on analysis using the 2001 National Land Cover Database (NLCD; Homer and others, 2007). The most developed areas are in the southern part of the study area that encompasses parts of the Springfield, Mass., to Stamford, Conn., metropolitan areas, whereas much of the northern part of the study area is substantially forested, including the Green Mountains in Vermont and the White Mountains in New Hampshire.

\section{Data Collection, Data Sources, and Methods of Data Analysis}

The computation of total nitrogen loads required retrieval of water-quality and streamflow data from USGS databases from October 1995 through September 2009 at waterquality monitoring and streamgage stations in the study area. Some available load estimates from the northern part of the watershed were used. Total nitrogen loads at each station were computed by using the LOADEST (load estimator) program (Runkel and others, 2004). Samples were collected as part of previously established water-quality networks and specifically for this investigation. Streamflow data for all stations used in the analyses were previously collected at streamgages at or near the water-quality monitoring stations.

Computed loads were used along with ancillary basin information in the creation of a generalized least squares (GLS) regression model to describe the variability in nitrogen yields on the basis of land use, streamflow, and wastewater discharge of nitrogen. This regression model was applied to unmonitored areas in coastal Connecticut in order to estimate loads from these regions.

Annual combined estimates of total nitrogen loads from the study area, were made by summing the loads computed using LOADEST at the fall-line stations with the estimates of total nitrogen loads from the unmonitored areas downstream from the fall-line stations.

\section{Water-Quality Field Measurement and Sampling Procedures, and Streamflow Measurement}

Water-quality sampling methods and equipment selection for samples collected for this study are described in U.S. Geological Survey (2006) and Lane and others (2003). Samples were collected using an equal width increment method by compositing samples from at least 10 equally spaced locations across the stream channel. Field measurements were made during each station visit, including specific conductance, temperature, $\mathrm{pH}$, dissolved oxygen, and turbidity. The methods are described in Wilde (variously dated). Water-quality samples for nutrient analyses were preserved as needed and stored on ice before shipping within three days to the USGS National Water Quality Laboratory in Denver, Colorado. Streamflow measurements, streamgage operations, and discharge computations were done following the procedures described in Rantz (1982a,b). 


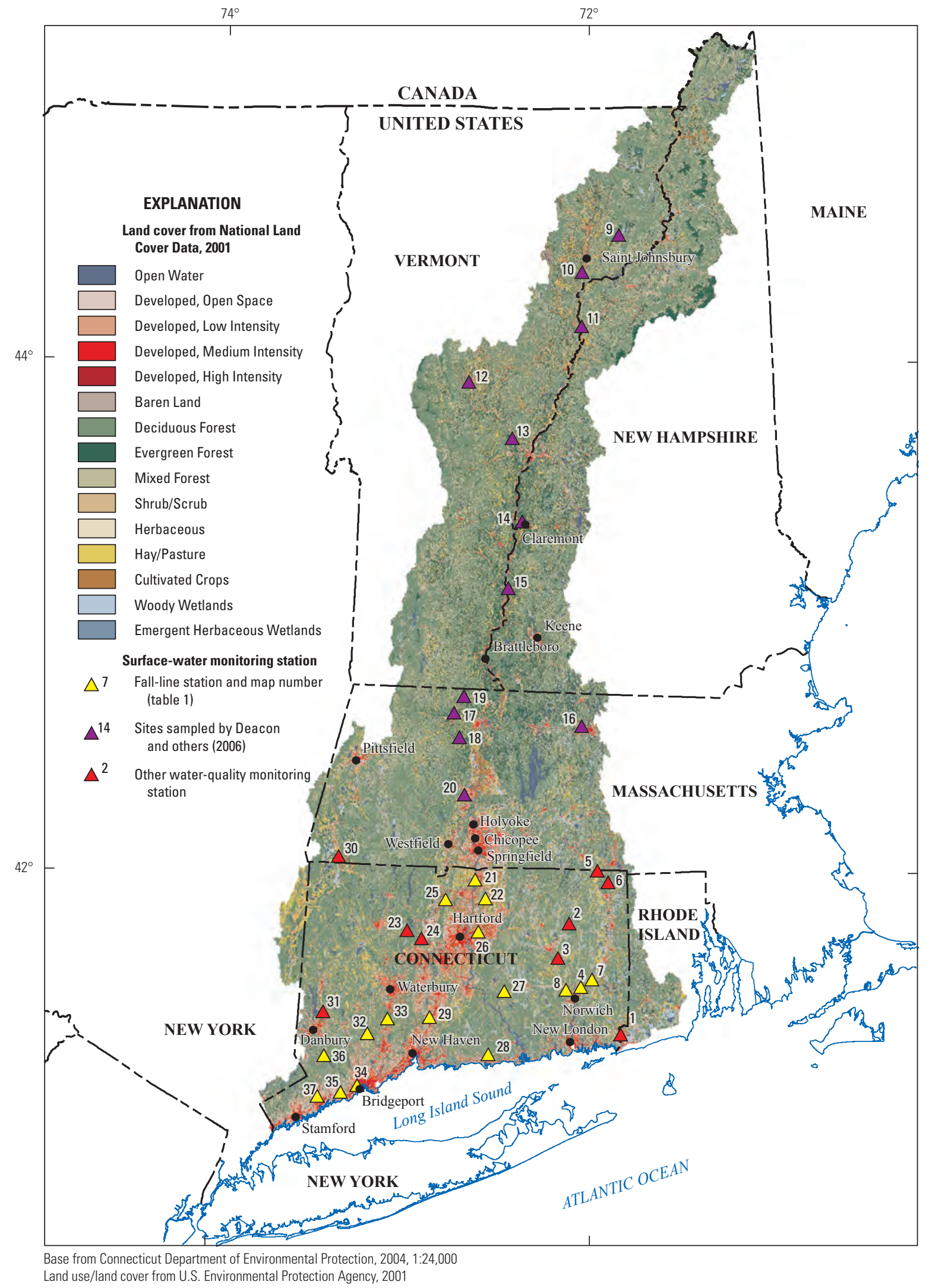

Figure 1. Long Island Sound watershed in the northeastern United States, with land cover and selected waterquality monitoring stations on rivers draining to Long Island Sound, northeastern United States. 


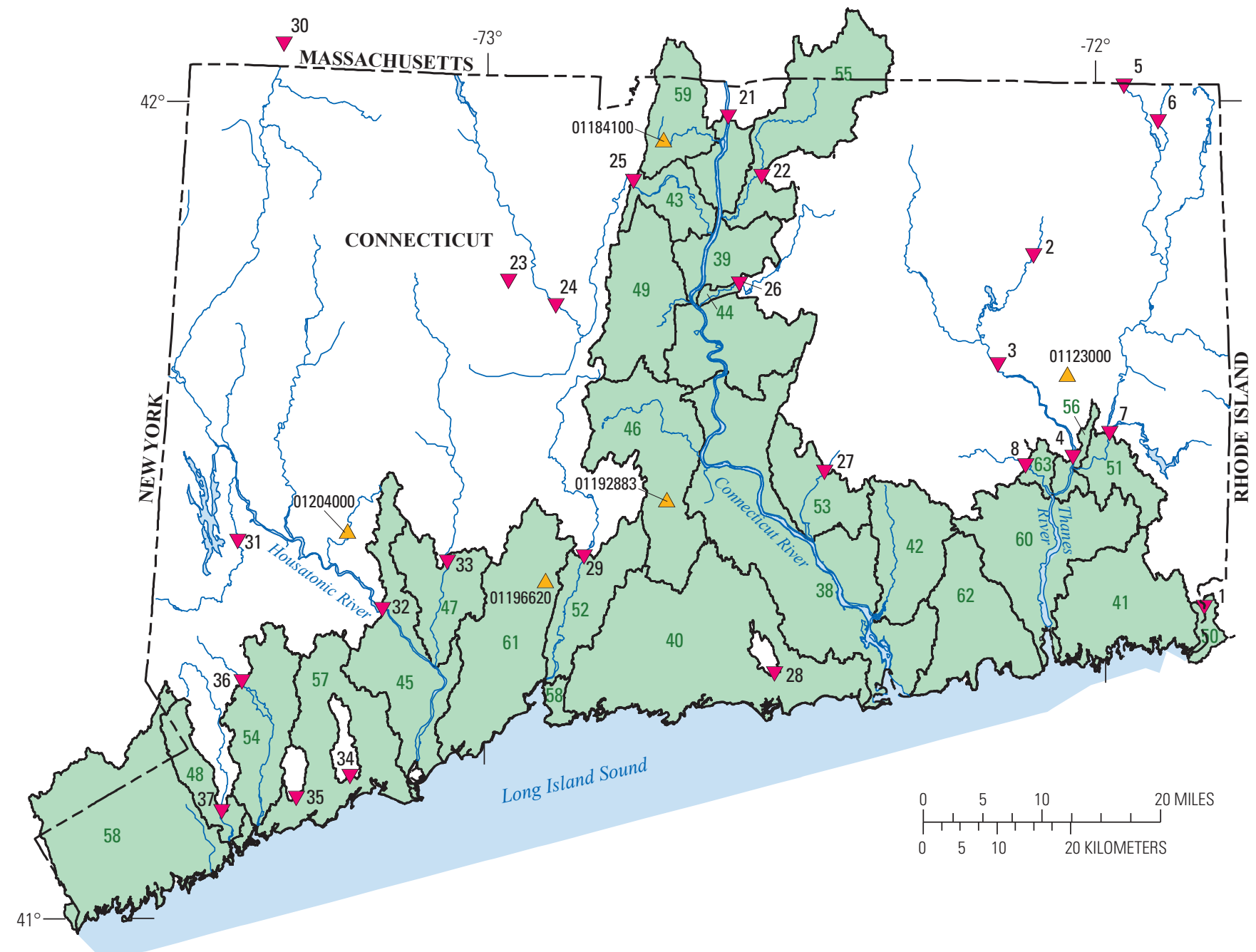

Base from Connecticut Department of Environmental Protection, 1994, 1:24,000

\section{EXPLANATION}

Unmonitored areas and map number (table 2)

$\nabla 29$ Water-quality monitoring station and map number (figure 1, table 1)

01123000

$\triangle \quad$ Surrogate streamgage and identifier (table 3)

Figure 2. Unmonitored areas draining to Long Island Sound, water-quality monitoring stations, and surrogate streamgages in parts of Connecticut, Rhode Island, Massachusetts, and New York. 


\section{Laboratory Measurements}

Total nitrogen was calculated as the sum of total ammonia plus organic nitrogen and nitrite plus nitrate nitrogen. Total ammonia plus organic nitrogen and nitrite plus nitrate nitrogen were analyzed using the methods detailed in Fishman (1993) and Patton and Truitt (2000). Analytical results were entered into the National Water Information System (NWIS) database by laboratory personnel. In the study area, total nitrogen concentrations contained varying proportions of nitrite plus nitrate nitrogen and total ammonia plus organic nitrogen. In samples from this study, nitrite plus nitrate nitrogen typically represented about 46 to 68 percent of the total nitrogen with median ratios in samples from some stations as low as low as 27 percent or as high as 90 percent. The percent of the total nitrogen from nitrite plus nitrate nitrogen typically increased with increasing urbanization in the watershed.

\section{Quality Assurance and Quality Control Sampling and Analysis}

Quality assurance and quality control (QA/QC) samples were collected and analyzed routinely for the constituents in total nitrogen, including total ammonia plus organic nitrogen and nitrite plus nitrate nitrogen. Field blanks were collected to determine whether the samples may have been contaminated with the analytes of interest as a result of the sampling, storage, and shipping procedures or the exposure of the sampling equipment to the environment. Split replicates were collected primarily to determine the reproducibility of the analytical data and the potential bias from preservatives, filtering, and shipping of the samples. Procedures for field blanks and split replicates are described in U.S. Geological Survey (2006).

Water samples for analysis for total nitrogen concentration were collected as part of several projects or programs during 1995 through 2009; therefore, all QA/QC data for total nitrogen associated with any of the stations in this study were evaluated. Field blanks were collected 95 times at 25 stations. Concentrations of total nitrogen in all field blanks were less than the reporting limit and ranged from less than 0.07 to less than $0.43 \mathrm{mg} / \mathrm{L}$. In three field blank samples, concentrations of total ammonia plus organic nitrogen were greater than the reporting limit $(0.10 \mathrm{mg} / \mathrm{L})$, ranging from 0.21 to $0.41 \mathrm{mg} / \mathrm{L}$. In one sample, the concentration of nitrite plus nitrate nitrogen, $0.3 \mathrm{mg} / \mathrm{L}$, was greater than the maximum reporting limit $(0.06 \mathrm{mg} / \mathrm{L})$. The results of these analyses indicate low potential for bias associated with the equipment used, the environments around the sampling sites, and the sample processing.

Split replicates were collected 96 times at 25 sites. The relative percent difference in total nitrogen concentrations between the environmental samples and the split replicates ranged from a low of -20 percent to a high of +34.62 percent.
The 25 th percentile was -3.22 and the 75 th percentile was +2.35 percent, indicating that most of the analytical results were reproducible. These relative percent differentials translate to a small absolute difference in analytical results. The minimum was $-0.19 \mathrm{mg} / \mathrm{L}$, the maximum was $+0.11 \mathrm{mg} / \mathrm{L}$, and the 25 th and 75 th percentiles were -0.01 and $+0.02 \mathrm{mg} / \mathrm{L}$, respectively, indicating little variability in the analytical results.

\section{Load Estimation Data}

Most of the data used in this study are from chemical analyses of water samples and from streamflow data collected at 25 streamgages (table 1) in the Long Island Sound watershed in Connecticut as part of the USGS Cooperative Water Program. Some of the water-quality data were obtained as part of the USGS National Water-Quality Assessment program. Data on discrete total nitrogen concentrations and mean daily streamflow were retrieved from NWIS in 2011. All available data from October 1995 through September 2009 (water years 1996-2009) were retrieved; total nitrogen represents the sum of total ammonia plus organic nitrogen and nitrate plus nitrite nitrogen concentrations stored in the NWIS database. Sample collection frequency at individual stations ranged from 4 samples per year to 22 samples per year for the available period of record, which ranged from 2 to 14 years.

Water-quality load analyses from an additional 12 stations (fig. 1; table 1) used in this study were made as part of a study of nitrogen loads in the northern part of the Connecticut River Basin (Deacon and others 2006). These data represent water years 2003-5.

\section{Load Computation for Monitoring Stations}

Total nitrogen loads were computed by using the LOADEST computer program (Runkel and others, 2004). Given a set of discrete water-quality measurements at each station and corresponding streamflow data, LOADEST develops a regression model for the estimation of constituent load. Explanatory variables in the regression model may include various functions of streamflow, time, seasonal terms, and additional user-specified data. The formulated regression model then is used to estimate loads over a user-specified time interval.

The LOADEST program uses adjusted maximum likelihood estimation (AMLE; Cohn, 1988; Cohn and others, 1992) because the dataset can contain censored data (below an analytical or reporting threshold). Retransformation bias (underestimation of true loads resulting from changing estimates made in log space back to actual numbers) is handled in the AMLE by equations specially designed for censored data. Load estimations using datasets with no censored data converge to the maximum likelihood estimation (MLE); either estimation method, used appropriately, results in a minimum-variance, unbiased estimate of constituent loads 


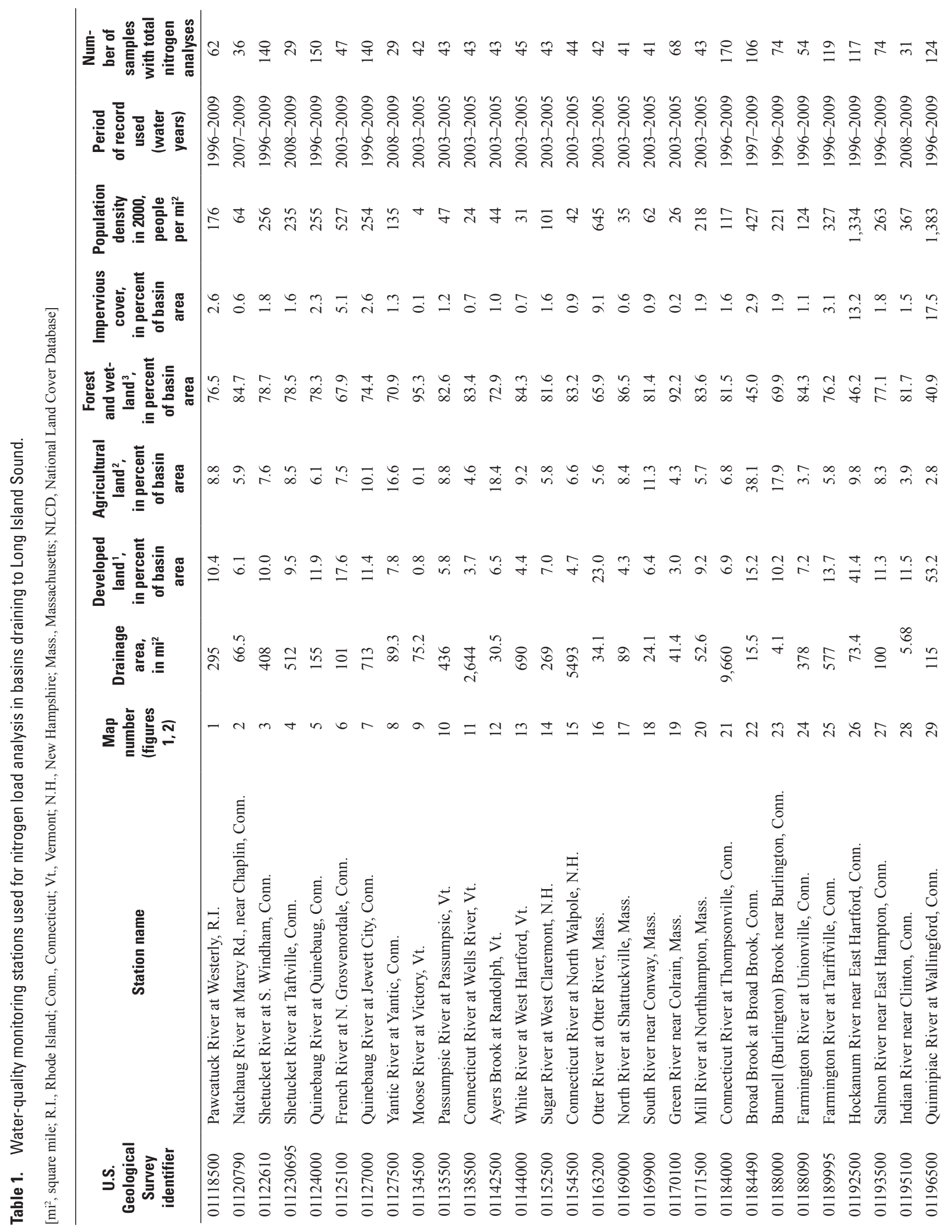




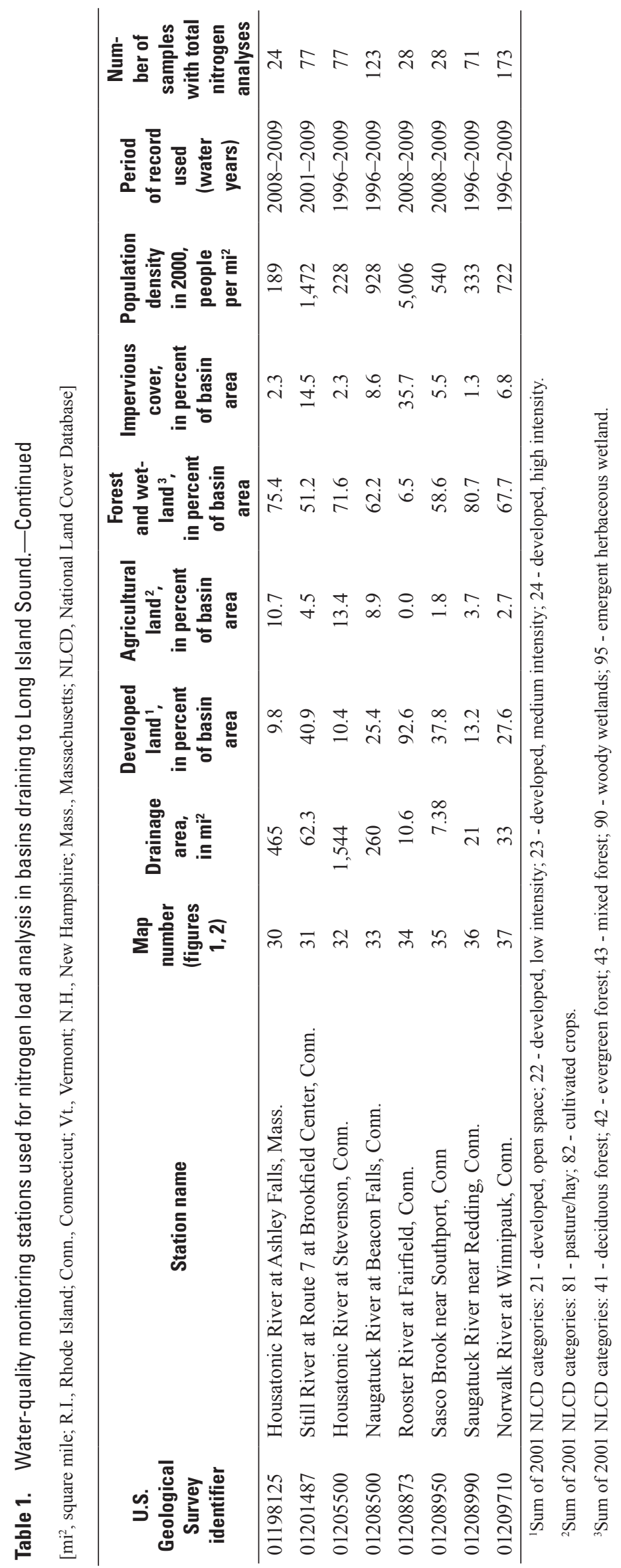


(Runkel and others, 2004). Data analyzed for total nitrogen in this study contained no censored data. Where either nitrite plus nitrate nitrogen or total ammonia plus organic were detected at greater than the reporting limit, no total nitrogen concentration was reported in NWIS.

Estimations using the AMLE or MLE require that model residuals are normally distributed. As part of the evaluation of models, plots of residuals were analyzed graphically to verify that residuals met or nearly met normality assumptions.

Load estimations were computed for water years 1999-2009. Input data sets for the LOADEST model contained concentrations of total nitrogen and continuous streamflow values for water years 1996-2009, if available, in order to improve the load estimations by including data prior to water year 1999. Load estimations using LOADEST are referred to as "computed loads" in this report.

\section{Load Estimation for Unmonitored Areas}

A multivariate regression model was developed to estimate annual nonpoint nitrogen yields for all 26 unmonitored areas that drain to Long Island Sound (fig. 2; table 2). These unmonitored areas are based on basin boundaries and include downstream parts of monitored basins and groups of coastal basins.

The regression model uses land use, streamflow, and point-source nitrogen data as independent variables to describe the variability of annual nitrogen yield (Mullaney and others, 2002). Computations of individual annual yields for water years 1999-2009 (based on LOADEST calculations described above) for each water-quality monitoring station were used in multivariate regression as the response variable.

Correlation among model residuals is present because (1) data for multiple years from the same monitoring station were used in the regression and (2) data for many of the explanatory variables were fixed and the same values were used for each year (land use and land cover, for example). To account for this correlation, a GLS model with a serially correlated error structure was applied. This regression method allows for calculation of unbiased coefficient estimates and confidence intervals around estimates of predicted yields. A detailed description of these methods is in Mullaney and others (2002, appendix 2). Estimates of total nitrogen loads from the unmonitored basins were combined with the computed loads from the fall-line monitoring stations to estimate the total nitrogen loads delivered to Long Island Sound from the study area for the period of interest.

Data sets used in describing the variability of nitrogen yields included land use and land cover from 2001, annual streamflows, and loads of nitrogen discharged from wastewater-treatment facilities. Multiple combinations of variables were tested in the regression. Variables were selected on the basis of physical plausibility, inspection of plots of residuals, and other statistical diagnostics. The goal was to describe the greatest amount of variability with the fewest number of variables.

\section{Land Use and Land Cover}

Selected land-use and land-cover data were summarized for basins analyzed in this study from interpreted Landsat images from the NLCD for 2001 (U.S. Environmental Protection Agency, 2001; Homer and others, 2007). The NLCD 2001 is a 16-class land-cover classification scheme that has been applied consistently across all 50 States and Puerto Rico at a spatial resolution of 30 meters. The NLCD 2001 is based primarily on the unsupervised classification of Landsat Enhanced Thematic Mapper+ satellite data from about 2001.

\section{Streamflow and Water Yield}

One of the most important factors in determining annual total nitrogen loads from a river is the annual variability of streamflow. Therefore, the annual streamflow for each streamgage, normalized to drainage area and resulting in water yields, was used as an explanatory variable to estimate the annual yields of total nitrogen. Annual mean streamflow data for each streamgage (with LOADEST computations) was converted to inches of runoff per year, for each year as done by Mullaney and others (2002).

In order to apply the annual runoff variable when making predictions for the unmonitored areas, streamflow data from streamgages (table 3 ) in or near each unmonitored area, called "surrogate streamgages," were used to estimate annual mean streamflow and runoff. Most surrogate streamgages were selected from basins with no major wastewater discharges. The use of this surrogate streamgage approach does not account for diversions of water that might be present in each unmonitored basin; therefore, estimates may be biased low or high if substantial amounts of water are imported from, or exported to, any unmonitored basin. During the period of the study (water years 1999-2009), runoff in Connecticut exceeded the median value of 27.1 inches for the 30-year period of water years 1980-2009 in 6 of the 11 years studied, primarily toward the end of the record (fig. 3; U.S. Geological Survey, 2012).

\section{Wastewater Nitrogen}

WWTF nitrogen load data were derived from two sources: (1) data on loads reported to the Connecticut Department of Energy and Environmental Protection (CTDEEP) by WWTFs in Connecticut and (2) output data from the USGS SPARROW model for facilities north of Connecticut (Moore and others, 2011). CTDEEP data include calendar year loads for all WWTFs in Connecticut for 1999 to 2002 and monthly loads reported by all Connecticut 
Table 2. Unmonitored areas draining to Long Island Sound, Connecticut and Rhode Island.

[mi², square mile; CT, Connecticut; S., south; N., north; NLCD, National Land Cover Database]

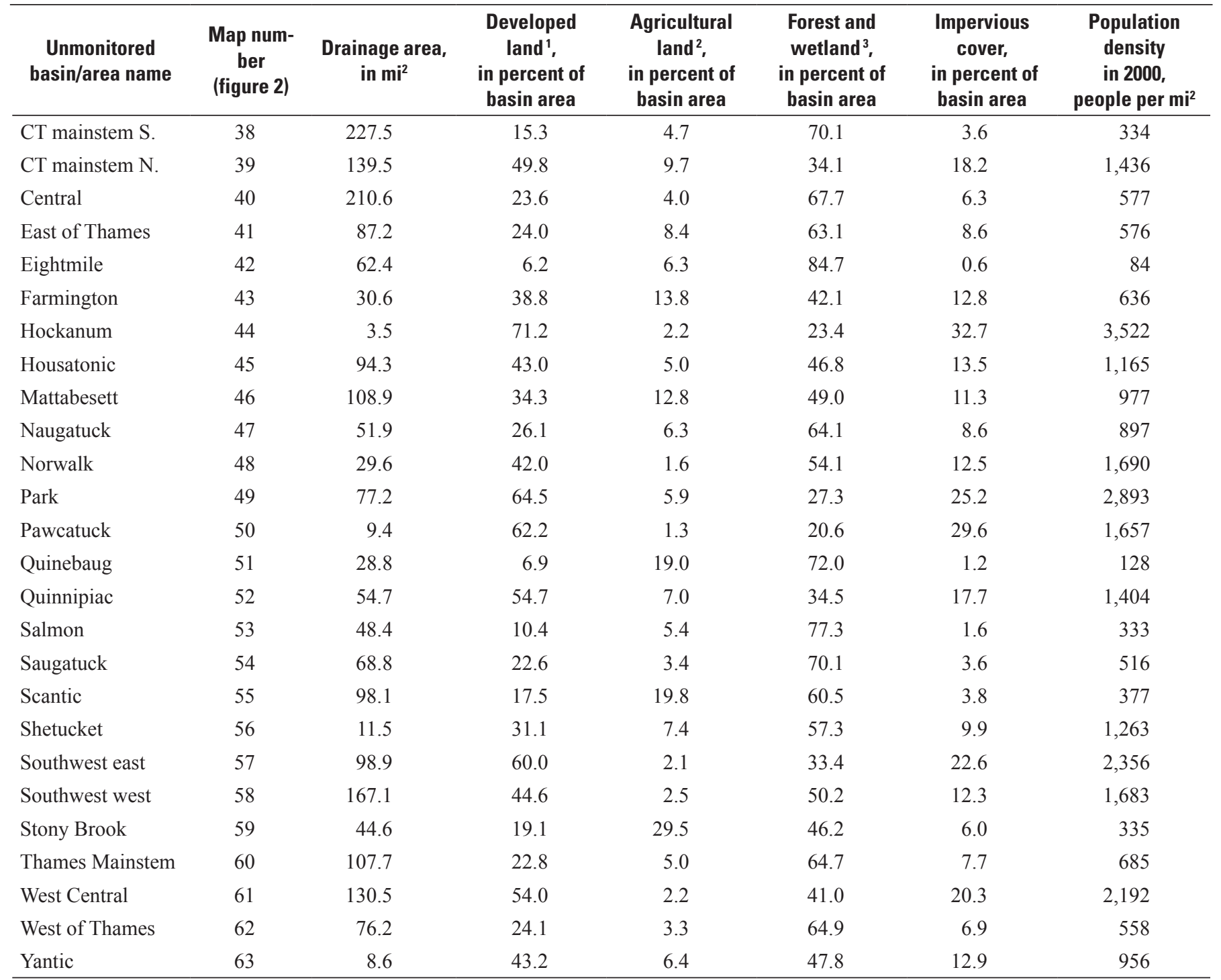

${ }^{1}$ Sum of 2001 NLCD categories: 21 - developed, open space; 22 - developed, low intensity; 23 - developed, medium intensity; 24 - developed, high intensity.

${ }^{2}$ Sum of 2001 NLCD categories: 81 - pasture/hay; 82 - cultivated crops; 90 - woody wetlands; 95 - emergent herbaceous wetland.

${ }^{3}$ Sum of 2001 NLCD categories: 41 - deciduous forest; 42 - evergreen forest; 43 - mixed forest.

facilities for 2002 to 2009 as part of the CTDEEP Nitrogen Credit Exchange program (NCE; Connecticut Department of Environmental Protection, 2010). Monthly WWTF nitrogen loads were summed by water year to conform with the LOADEST outputs. Data for 1999 through 2002 were summarized by calendar year because monthly data were not available prior to the implementation of the NCE in 2001. Data on nitrogen loads from WWTFs in Connecticut are in appendix 3 , and summed by station in appendix 1 .
The loads of nitrogen from WWTFs in Connecticut have decreased steadily following the implementation of the NCE, both upstream from USGS monitoring stations and in the unmonitored coastal areas (shown in fig. 2). Loads from Connecticut WWTFs upstream from USGS fall-line monitoring stations declined from a high of 5.3 million pounds per year (Mlb/yr) in calendar year 1999 to a low of 3.4 Mlb/yr in water year 2008 (fig. 4). Loads of total nitrogen from WWTFs in the unmonitored coastal basins (downstream 
Table 3. Surrogate streamgages selected to represent unmonitored basins that drain to Long Island Sound.

[USGS, U.S. Geological Survey; CT, Connecticut; S., south; N., north; Conn., Connecticut; R.I., Rhode Island]

\begin{tabular}{|c|c|c|c|}
\hline \multirow{2}{*}{$\begin{array}{l}\text { Unmonitored } \\
\text { area, or water- } \\
\text { quality site } \\
\text { (figures } 1 \text { and 2) }\end{array}$} & \multirow{2}{*}{$\begin{array}{l}\text { Unmonitored basin } \\
\text { or part of basin }\end{array}$} & \multicolumn{2}{|r|}{ Streamgage used as surrogate } \\
\hline & & $\begin{array}{c}\text { USGS } \\
\text { station number }\end{array}$ & Station name \\
\hline 40 & CT mainstem $\mathrm{S}$. & 01193500 & Salmon River near East Hampton, Conn. \\
\hline 41 & CT mainstem $\mathrm{N}$. & 01184490 & Broad Brook at Broad Brook, Conn. \\
\hline 42 & Eightmile & 01193500 & Salmon River near East Hampton, Conn. \\
\hline 43 & Farmington & 01184100 & Stony Brook near West Suffield, Conn. \\
\hline 44 & Hockanum & 01192500 & Hockanum River near East Hartford, Conn \\
\hline 45 & Housatonic & 01204000 & Pomperaug River at Southbury, Conn. \\
\hline 46 & Mattabesett & 01192883 & Coginchaug River at Middlefield, Conn. \\
\hline 47 & Scantic & 01184490 & Broad Brook at Broad Brook, Conn. \\
\hline 48 & Stony Brook & 01184100 & Stony Brook near West Suffield, Conn. \\
\hline 49 & Park & 01184100 & Stony Brook near West Suffield, Conn. \\
\hline 50 & Salmon & 01193500 & Salmon River near East Hampton, Conn. \\
\hline 51 & Yantic & 01127500 & Yantic River at Yantic, Conn. \\
\hline 52 & Shetucket & 01193500 & Salmon River near East Hampton, Conn. \\
\hline 53 & Quinebaug & 01123000 & Little River near Hanover, Conn. \\
\hline 54 & Pawcatuck & 01118500 & Pawcatuck River at Westerly, R.I. \\
\hline 55 & Thames Mainstem & 01127500 & Yantic River at Yantic, Conn. \\
\hline 56 & East of Thames & 01127500 & Yantic River at Yantic, Conn. \\
\hline 57 & West of Thames & 01127500 & Yantic River at Yantic, Conn. \\
\hline 58 & Central & 01195100 & Indian River near Clinton, Conn. \\
\hline 59 & Quinnipiac & 01196500 & Quinnipiac River at Wallingford, Conn. \\
\hline 60 & West Central & 01196620 & Mill River near Hamden, Conn. \\
\hline 61 & Naugatuck & 01208500 & Naugatuck River at Beacon Falls, Conn. \\
\hline 62 & Saugatuck & 01208990 & Saugatuck River near Redding, Conn. \\
\hline 63 & Norwalk & 01209710 & Norwalk River near Winnipauk, Conn. \\
\hline 64 & Southwest_east & 01208950 & Sasco Brook near Southport, Conn. \\
\hline 65 & Southwest_west & 01208950 & Sasco Brook near Southport, Conn. \\
\hline 4 & 011230695 & 01127500 & Yantic River at Yantic, Conn. \\
\hline
\end{tabular}

from USGS monitoring stations) declined from a high of $13.1 \mathrm{Mlb} / \mathrm{yr}$ in calendar year 1999 to a low of $7.3 \mathrm{Mlb} / \mathrm{yr}$ in water year 2009 (fig. 4). Annual total nitrogen load data from WWTFs were summed by water-quality monitoring station or unmonitored area and normalized by dividing by the drainage area of each basin to calculate a yield, in pounds per square mile $\left(\mathrm{lb} / \mathrm{mi}^{2}\right)$. Annual summaries of nitrogen load from WWTFs in Connecticut are listed in appendix 3.

Annual or monthly total nitrogen load data from WWTFs in basins outside Connecticut were generally unavailable. Therefore, nitrogen load estimates from WWTFs for those basins (table 4; Moore and others, 2011) were determined using the USGS SPARROW decision-support tool (http://cida.usgs.gov/sparrow/). Nitrogen load information used in the SPARROW model is based on 2002 estimates of nitrogen loads from a USEPA permitted wastewater-discharge dataset that was developed on the basis of the methods used by McMahon and others (2007) and described in Maupin and Ivahnenko (2011). Load estimates were assumed to be representative of the entire study period and were normalized by dividing the cumulative wastewater-discharge loads by the entire drainage basin for the monitoring station to calculate a yield, in pounds per square mile per year $\left(\mathrm{lb} / \mathrm{mi}^{2} / \mathrm{yr}\right)$. 


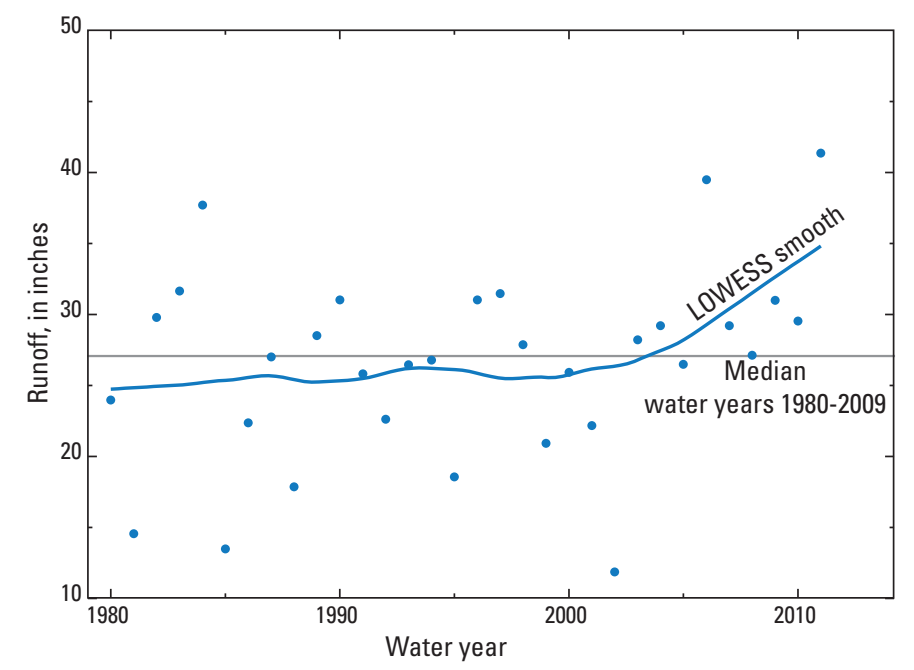

Figure 3. Runoff in Connecticut, water years 1980-2011, and median runoff, water years 1980-2009.

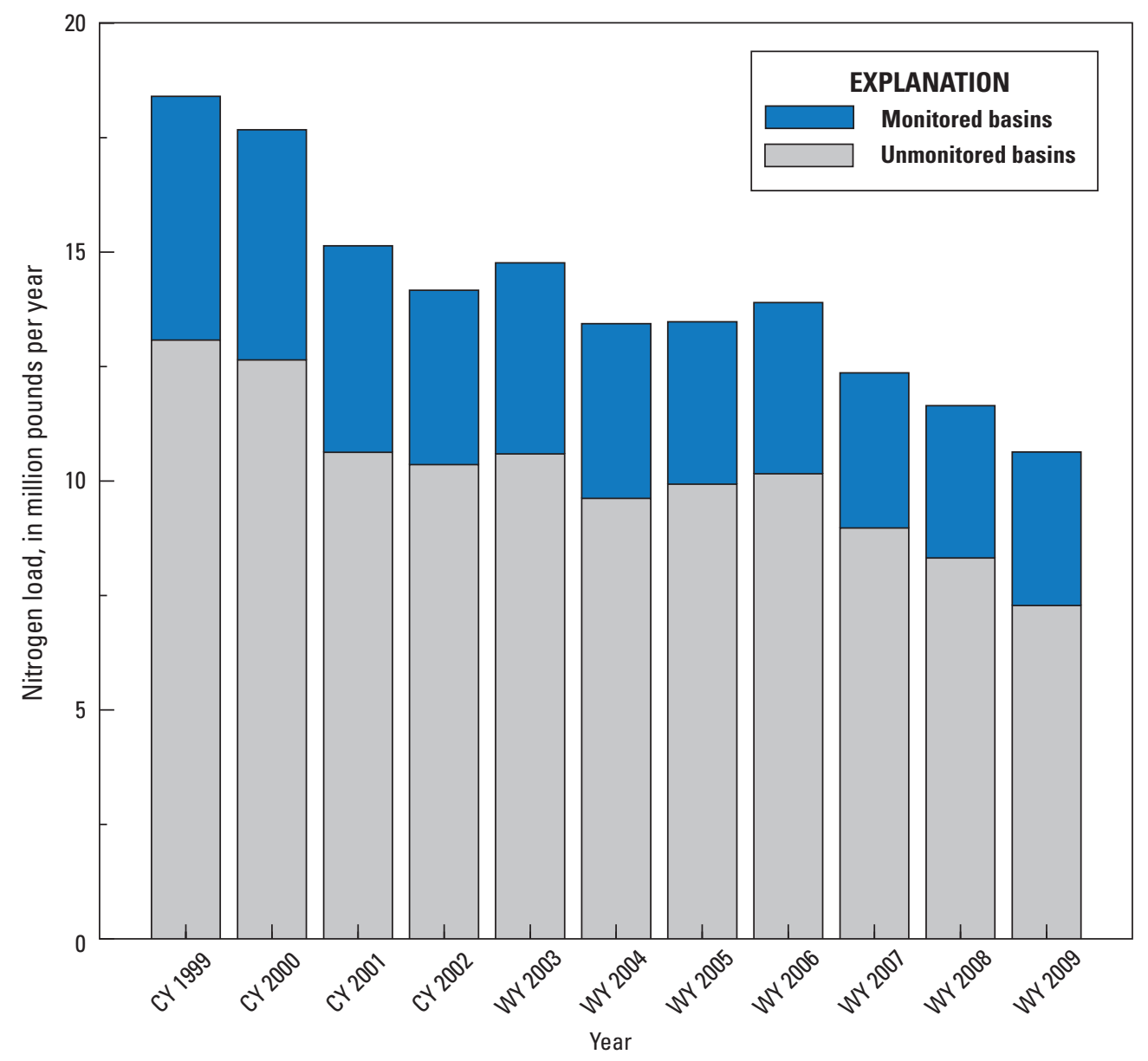

Figure 4. Loads of nitrogen discharged from Connecticut wastewater-treatment facilities in monitored and unmonitored basins draining to Long Island Sound, calendar years (CY) 1999-2002 and water years (WY) 2003-09. 
Table 4. Estimated cumulative nitrogen loads from wastewater-treatment facilities outside Connecticut for stations in the drainage area to Long Island Sound.

[USGS, U.S. Geological Survey; kg/yr, kilograms per year; lb/yr, pounds per year; Vt., Vermont; N.H., New Hampshire; Mass., Massachusetts; Conn., Connecticut]

\begin{tabular}{clcrr}
\hline $\begin{array}{c}\text { USGS } \\
\text { station } \\
\text { number }\end{array}$ & \multicolumn{1}{c}{ Station name } & $\begin{array}{c}\text { Map number } \\
\text { (figure 1) }\end{array}$ & $\begin{array}{c}\text { Nitrogen } \\
\text { load } \\
\text { (kg/yr) } \mathbf{1}^{\mathbf{c}}\end{array}$ & $\begin{array}{c}\text { Nitrogen } \\
\text { load } \\
\text { (lb/yr) }\end{array}$ \\
\hline 01135500 & Passumpsic River at Passumpsic, Vt. & 10 & 19,000 & 41,900 \\
01138500 & Connecticut River at Wells River, Vt. & 11 & 44,300 & 97,600 \\
01152500 & Sugar River at West Claremont, N.H. & 14 & 19,900 & 43,800 \\
01154500 & Connecticut River at North Walpole, N.H. & 15 & 194,000 & 428,000 \\
01163200 & Otter River at Otter River, Mass. & 16 & 44,500 & 98,000 \\
01184000 & Connecticut River at Thompsonville, Conn. & 21 & $1,790,000$ & $3,950,000$ \\
01198125 & Housatonic River near Ashley Falls, Mass. & 30 & 85,300 & 188,000 \\
01205500 & Housatonic River at Stevenson, Conn. & 32 & 85,300 & 188,000 \\
01125100 & French River at N. Grosvenordale, Conn. & 6 & 42,900 & 94,500 \\
01124000 & Quinebaug River at Quinebaug, Conn. & 5 & 61,200 & 135,000 \\
\hline
\end{tabular}

'Data from USGS SPARROW model by Moore and others (2011).

\section{Estimated Nitrogen Yields and Loads from Long Island Sound Tributaries}

Total nitrogen loads computed for 37 monitoring stations by means of LOADEST (appendix 2) were used to develop a GLS regression model describing the relations among annual total nitrogen yields and ancillary variables. This regression model was used to estimate total nitrogen yields from the unmonitored areas (shown in fig. 2) and from the fall-line monitoring stations that did not have the complete 11 years of water-quality data. Loads for each unmonitored area were then calculated by multiplying by drainage area. Load computations and estimates for the monitored and unmonitored areas were summed by Long Island Sound nitrogen management zones.

\section{Computed Nitrogen Yields and Loads at Monitoring Stations}

Median total nitrogen yields from mostly forested basins were typically less than $2,000 \mathrm{lb} / \mathrm{mi}^{2} / \mathrm{yr}$, whereas median yields from urbanized basins with no WWTFs were as high as $5,600 \mathrm{lb} / \mathrm{mi}^{2} / \mathrm{yr}$ and $13,100 \mathrm{lb} / \mathrm{mi}^{2} / \mathrm{yr}$ for basins with large nitrogen contributions from WWTFs. The highest yields were from the Broad Brook Basin (station 01184490; table 1) with a median nitrogen yield of $14,600 \mathrm{lb} / \mathrm{mi}^{2} / \mathrm{yr}$ for water years 1999-2009 (fig. 5; table 5; appendix 1). Broad Brook Basin has no WWTFs but contains the largest percentage of agricultural land of the basins that were sampled for this study (table 1; Mullaney, 2007). Basins with the highest yields do not necessarily represent a large amount of nitrogen load, if the basin areas are small. Nitrogen yield and load computations are given in appendix 2.

Total nitrogen yields at monitoring stations sampled in water years 1988-98 (Mullaney and others, 2002) and 1999-2009 were compared to determine whether there were any obvious changes resulting from management action in the Long Island Sound watershed to reduce total nitrogen loads (fig. 6). The median total nitrogen yields for most of the stations plot near the 1:1 line, indicating that median total nitrogen yields were generally similar for water years 1999-2009 and 1988-98. Median nitrogen yield values for some stations might not be comparable because of a short length of record during both periods (that is, 2 to 3 years).

Median total nitrogen yields were lower than during the 1988-98 period at several stations. Computed median total yields from the Naugatuck River at Beacon Falls (station 01208500 ) declined from 8,800 to $5,750 \mathrm{lb} / \mathrm{mi}^{2} / \mathrm{yr}$. The computed median total nitrogen yields at Hockanum River near East Hartford (station 01192500) also declined from 11,900 to $10,400 \mathrm{lb} / \mathrm{mi}^{2} / \mathrm{yr}$. Other declines included the Quinnipiac River at Wallingford (01196500) and Sasco Brook near Southport (01208950; appendix 2). Data from WWTFs in the Naugatuck River Basin above the monitoring station indicate a decline in total nitrogen load of about $1.3 \mathrm{Mlb} / \mathrm{yr}$ from calendar year 1999 to water year 2009 (appendix 1). Much of the improvement in the Naugatuck River is due to reconstruction of the City of Waterbury WWTF, which was completed in 2000 (Connecticut Department of Environmental Protection, 2001). Declines in total nitrogen yields at the Hockanum and Quinnipiac monitoring stations may be attributable to declines in nitrogen loads from WWTFs upstream from these sites (appendix 1). 


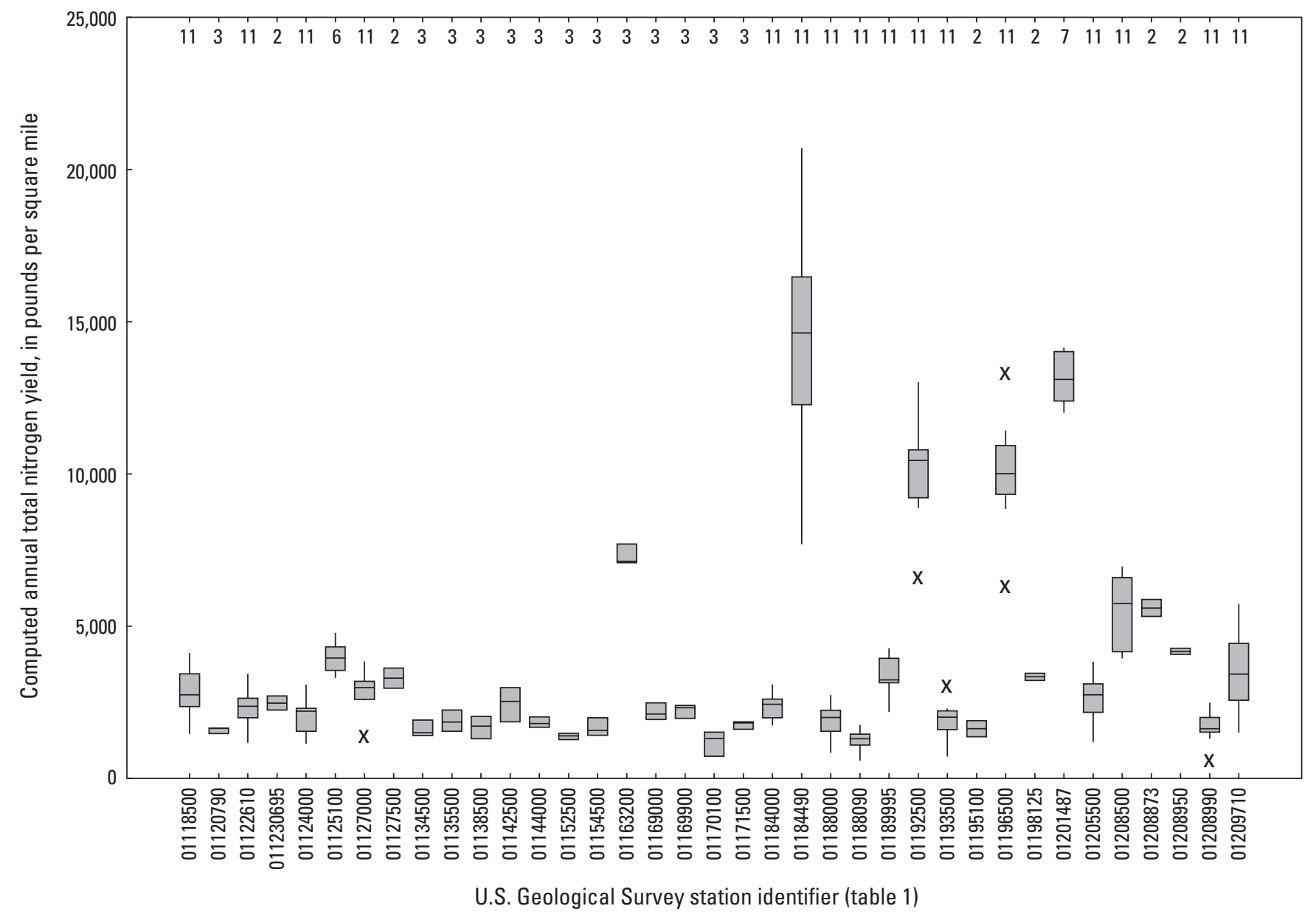

\footnotetext{
EXPLANATION

39 Number of values

Largest value within 1.5 times

interquartile range above

75th percentile

75th percentile

50th percentile

(median)

Interquartile

25th percentile

range

Smallest value within 1.5 times

interquartile range below

25th percentile

$\mathrm{x} \quad$ Outside value - Value is greater than 1.5

and less than 3 times the interquartile range

beyond either end of the box
}

Figure 5. Boxplots showing the distribution of computed annual total nitrogen yields from selected water-quality monitoring stations in basins draining to Long Island Sound, water years 1999-2009. 


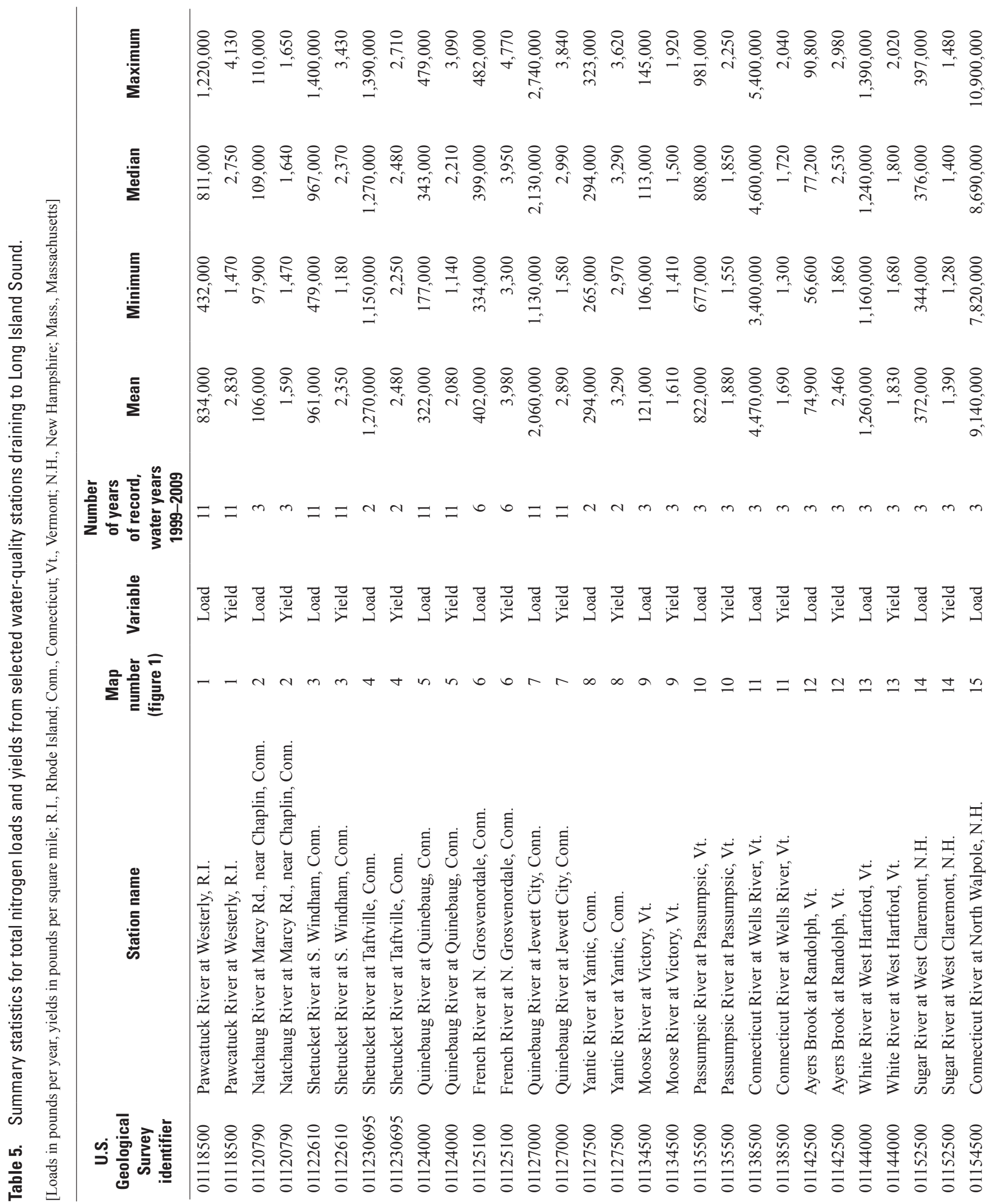




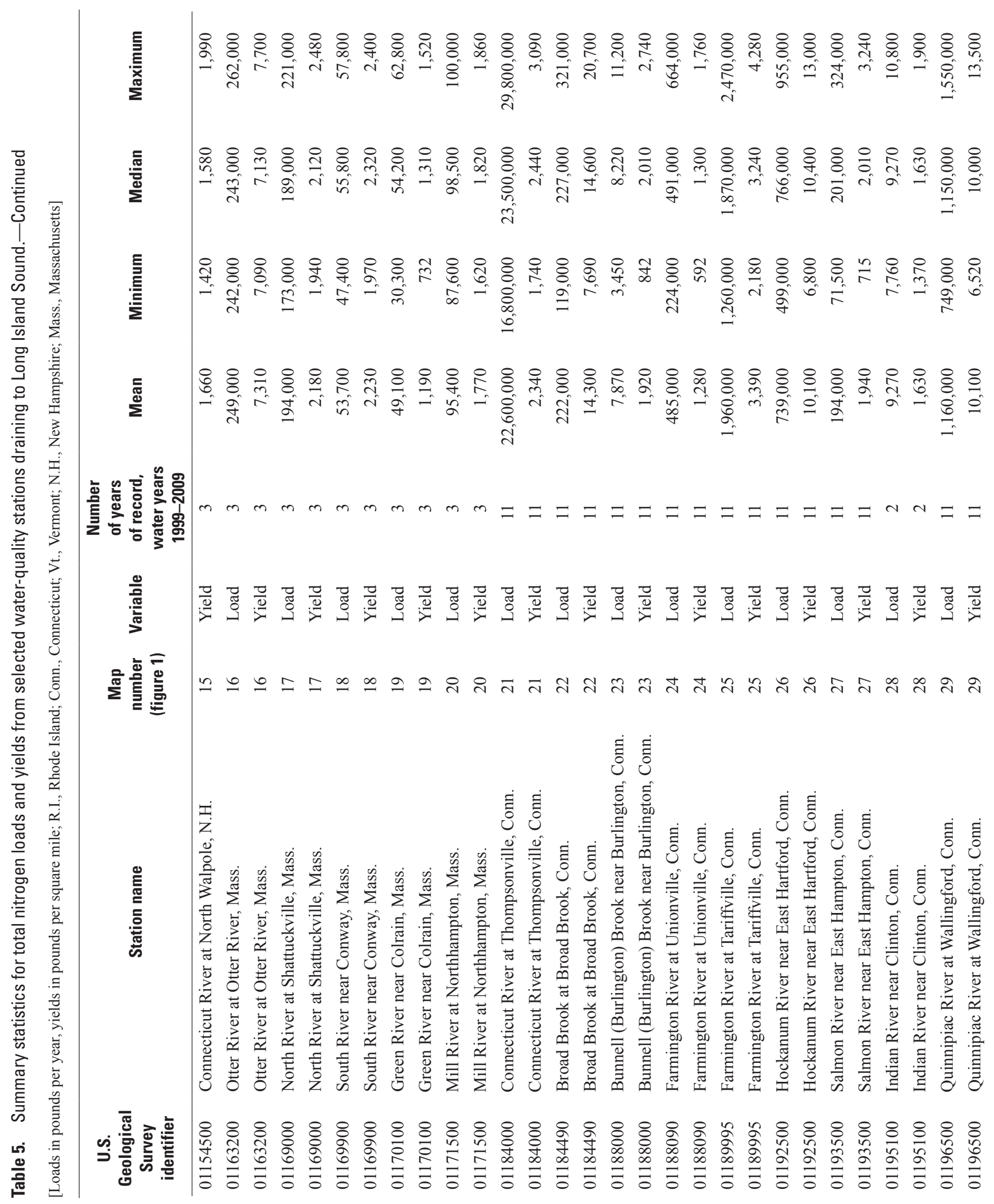




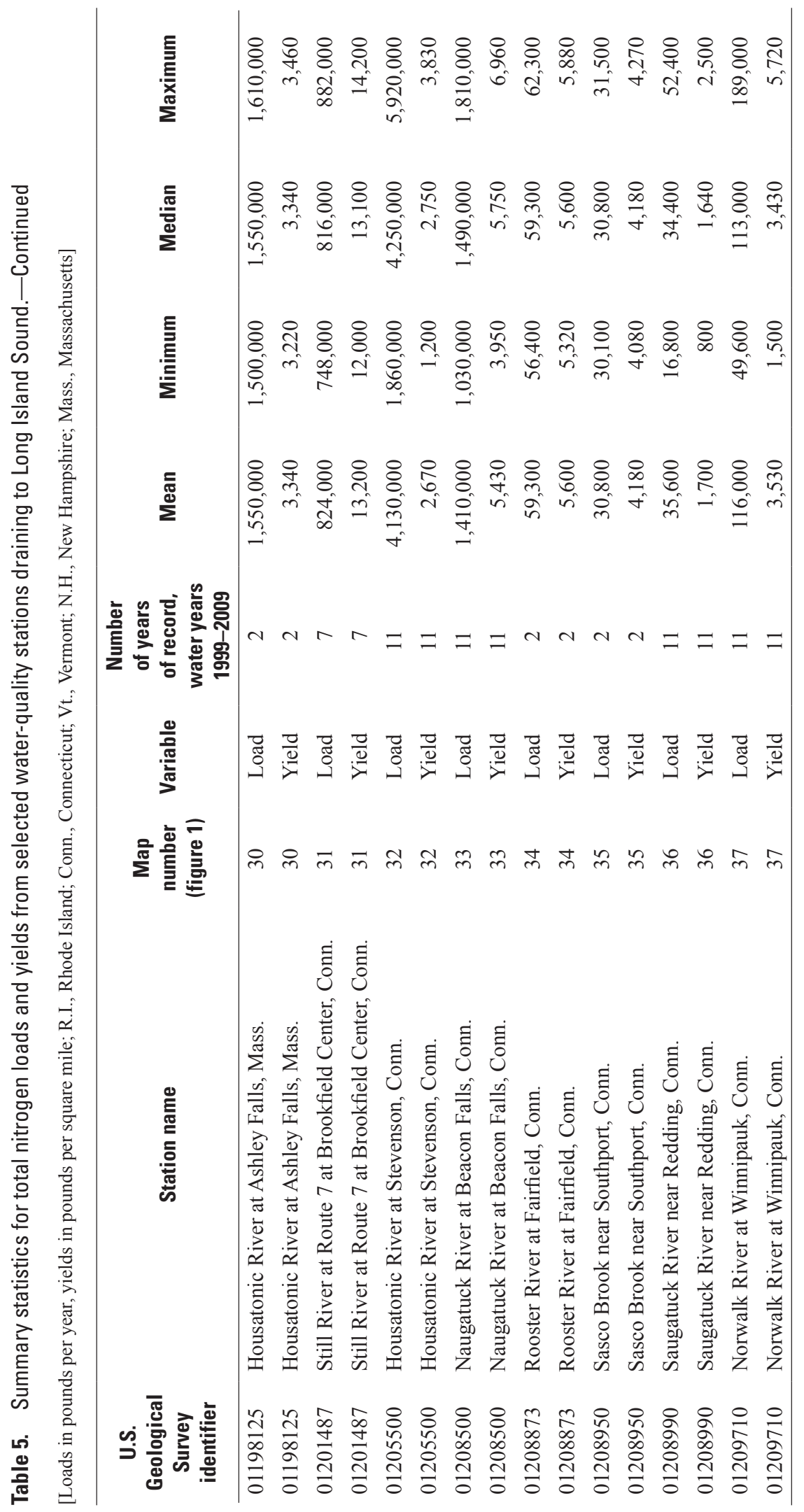




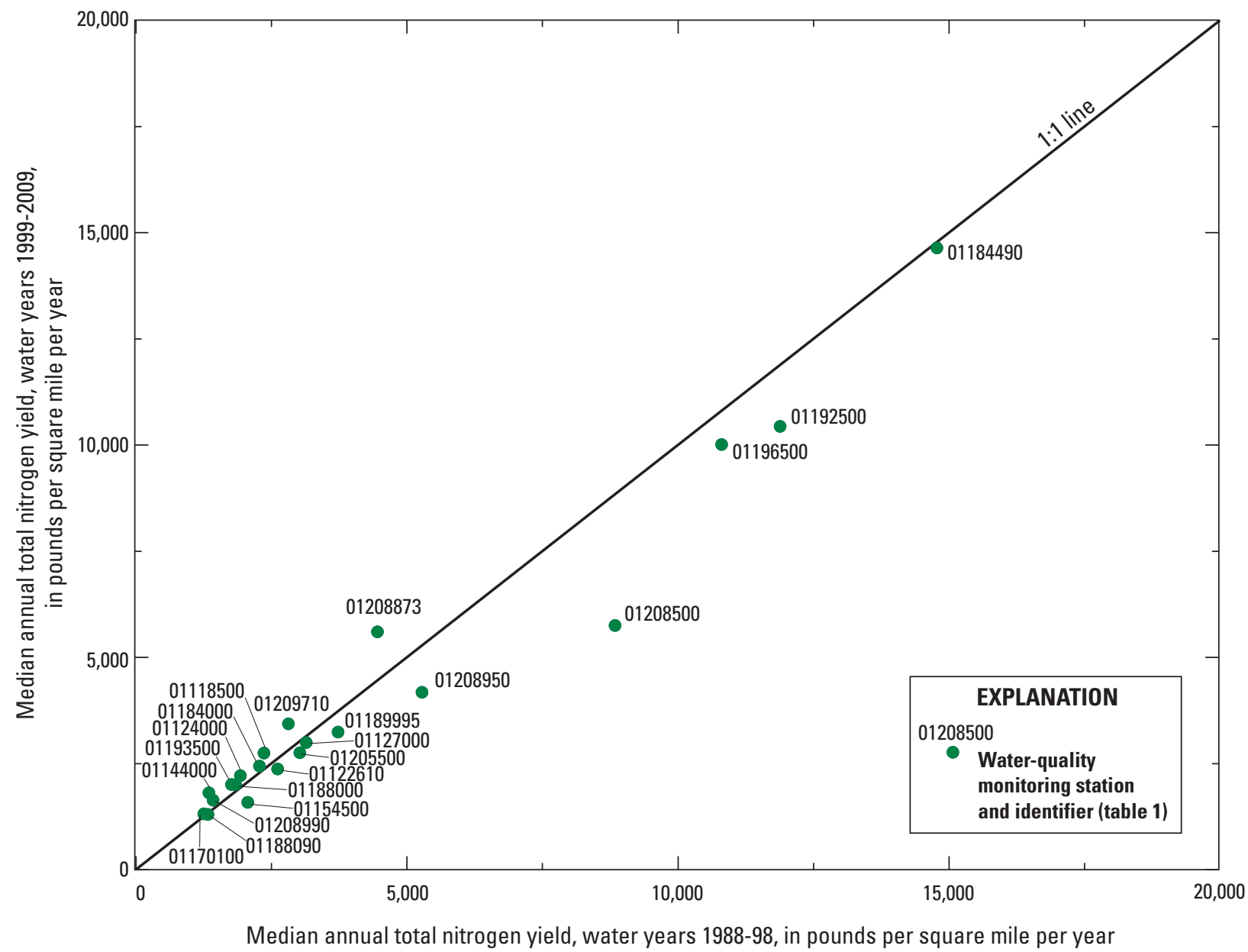

Figure 6. Median annual total nitrogen yields for water years 1988-98 in relation to those for water years 1999-2009 for basins draining to Long Island Sound.

Computed median total nitrogen yields at several stations increased, including the Norwalk River at Winnipauk (01209710) and the Rooster River near Fairfield (01208873) stations. The loads from WWTFs upstream from the Norwalk River monitoring station were small relative to those for other urbanized basins but increased by a factor of 1.5 from calendar year 1999 through water year 2009 (appendix 1). Even with declines in wastewater discharge of nitrogen from WWTFs, nitrogen yields at many stations for water years 1999-2009 were similar to those determined for water years 1988-98. One of the primary reasons for the similar yields, between the two time periods, may be attributable to increases in streamflow. Although there were substantial declines in pointsource nitrogen discharge, streamflows were greater than the median (fig. 3) for 6 of the 11 years analyzed, contributing to a greater than normal nonpoint-source nitrogen load. Summary statistics for load and yield data are presented in table 5; detailed data are reported in appendix 1.

\section{Estimated Total Nitrogen Yields and Loads from Unmonitored Areas}

The response variable in the regression model developed in this part of the study was total nitrogen yield, determined by using LOADEST with computed total nitrogen load outputs from 37 stations. Regression parameters were estimated using the GLS method, which transforms the regression data so that the resulting errors are independent and identically distributed. The linear transformation consists of multiplying all regression variables by the square root of the inverse of the error covariance matrix, estimated from the residuals of a first-stage ordinary least squares (OLS) model (Mullaney and others, 2002). The effect of the transformation is to ensure the resulting model residuals from a second-stage OLS regression are independent and identically distributed. The estimated coefficients and standard errors of the secondstage regression are unbiased and efficient. Because the final 
regression is based on transformed data, all plots of fit and of the distribution of model residuals also are plotted in the transformed space (figs. 7-9).

The transformation method employed in the derivation of the values plotted in figure 7 is a complex linear combination of the untransformed yields (see equation 8 in appendix 2 of Mullaney and others (2002) for a mathematical description of the transformation). The transformation results in values that adhere to desirable statistical properties, such as being approximately independent and having a common variance, but because negative coefficients are employed in the linear combination, negative values for the transformed yields may occur, and are likely if the untransformed yields are positive but small in value.

Explanatory variables were selected (table 6 ) by a trial and error process, by using variables that were similar to those used in the previous study (Mullaney and others, 2002), by evaluating plausibility, and by comparing significance and the distribution of residuals. The goal was to reduce the number of variables to as few as possible while minimizing bias in residuals. The land-use variables that were chosen (percentage of developed land use and percentage of cultivated crops) were fixed in time with data from the 2001 NLCD (U.S. Environmental Protection Agency, 2001). Two variables were used to represent the nitrogen loads from WWTFs: (1) nitrogen yields from WWTFs were calculated by summing the loads from the WWTFs upstream from the monitoring station and dividing by the drainage area and (2) the nitrogen yields from WWTFs outside Connecticut also were fixed by using outputs from the SPARROW model (Moore and others, 2011), which are based on an analysis of 2002 data. The annual mean runoff and the yields from WWTFs in Connecticut (CTpointyield) were variable from year to year and were the primary factors affecting annual variability in nitrogen yields. The coefficient of the CTpointyield variable was fixed at 1 , based on information from the SPARROW

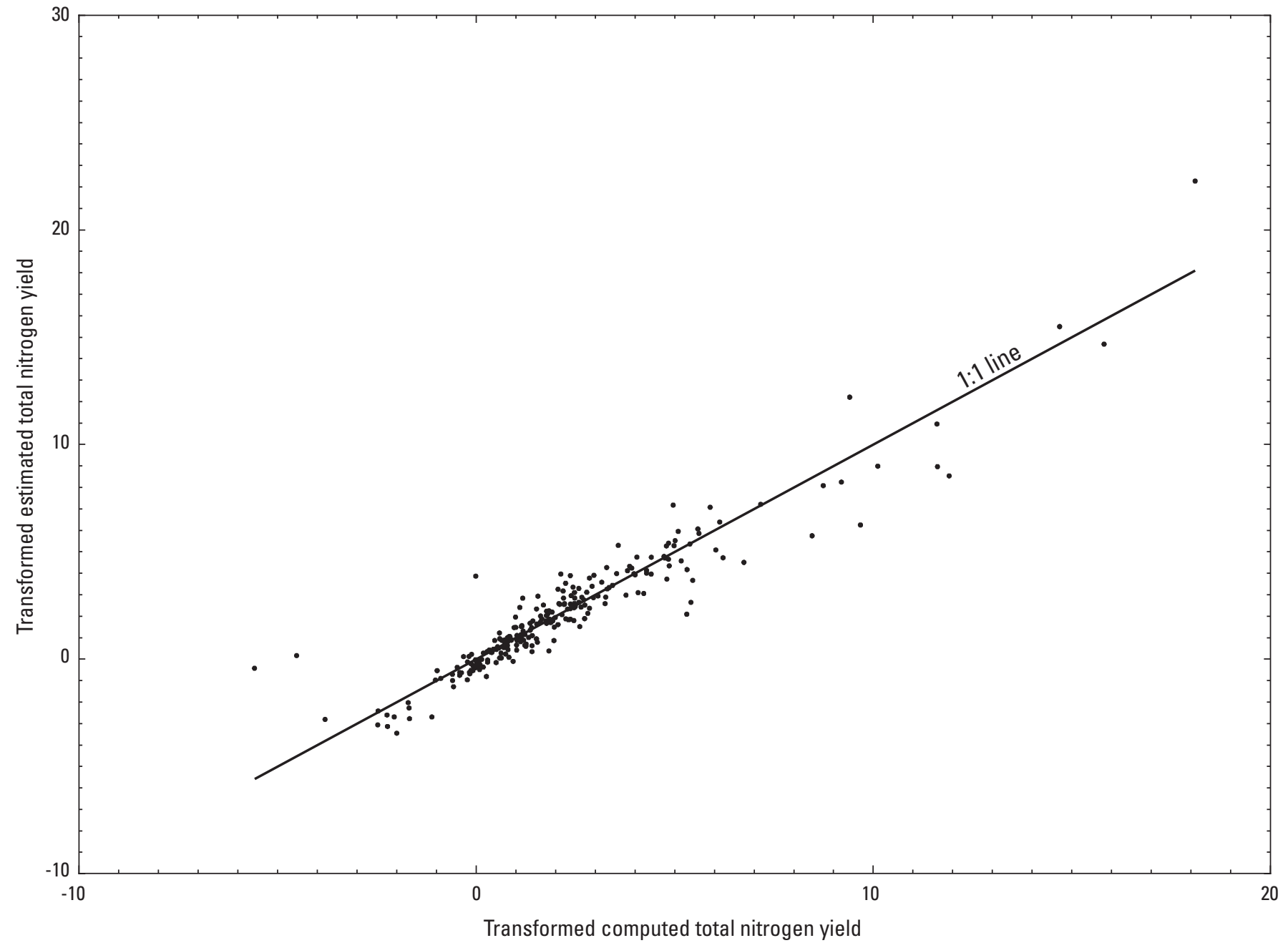

Figure 7. Transformed computed total nitrogen yield in relation to transformed estimated total nitrogen yield from monitored basins draining to Long Island Sound, water years 1999-2009. 

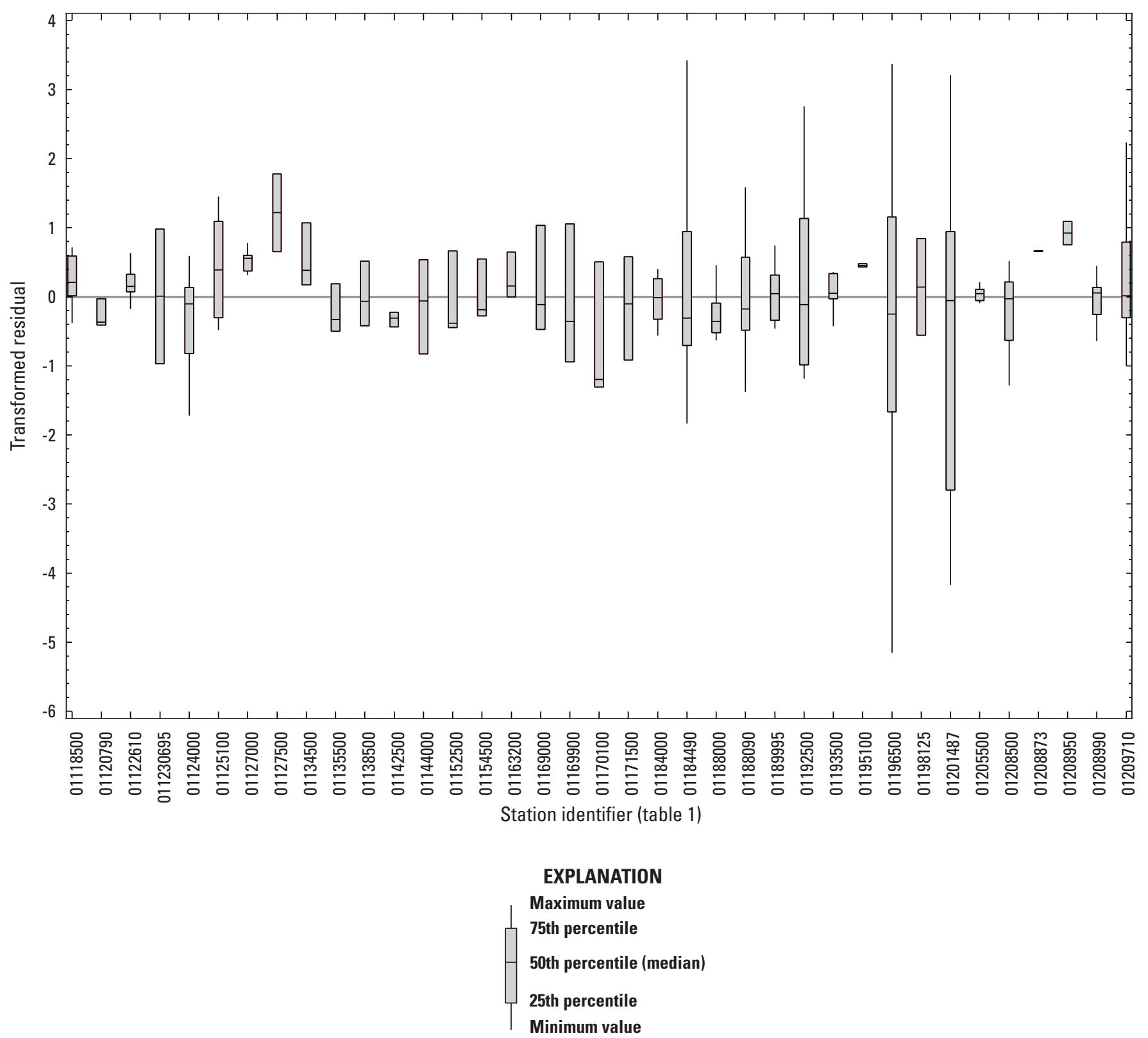

Figure 8. Transformed residuals, by station in basins draining to Long Island Sound, water years 1999-2009.

model (Moore and others, 2011) that indicated no attenuation of nitrogen was apparent in the analysis of data for the large rivers to which most wastewater-treatment facilities discharge. This fixed coefficient facilitated the calculation of total nitrogen yields in the unmonitored areas, many of which had discharges directly to Long Island Sound or to the estuaries of the major rivers. Therefore, the GLS regression coefficients were effectively calculated as if the CTpointyield was subtracted from the station yield.

Median annual total nitrogen yields estimated for the unmonitored areas (fig. 10; appendix 2) ranged from
1,630 lb/mi2/yr at the Eightmile basin (fig. 2, site 42; table 2), to $34,000 \mathrm{lb} / \mathrm{mi}^{2} / \mathrm{yr}$ for the lower reach of the Yantic basin (fig. 2, site 63; table 2). Yields for some basins are unusually high due to the location of WWTFs downstream from monitoring stations. For instance, the predicted yields for the Yantic basin represent only the most downstream part of the basin, a small drainage area downstream from the monitoring station, which contains a wastewater-treatment facility.

To account for uncertainties in the estimates caused by measurement error, a range of confidence intervals is provided, bounded by what are referred to as "inner" and 


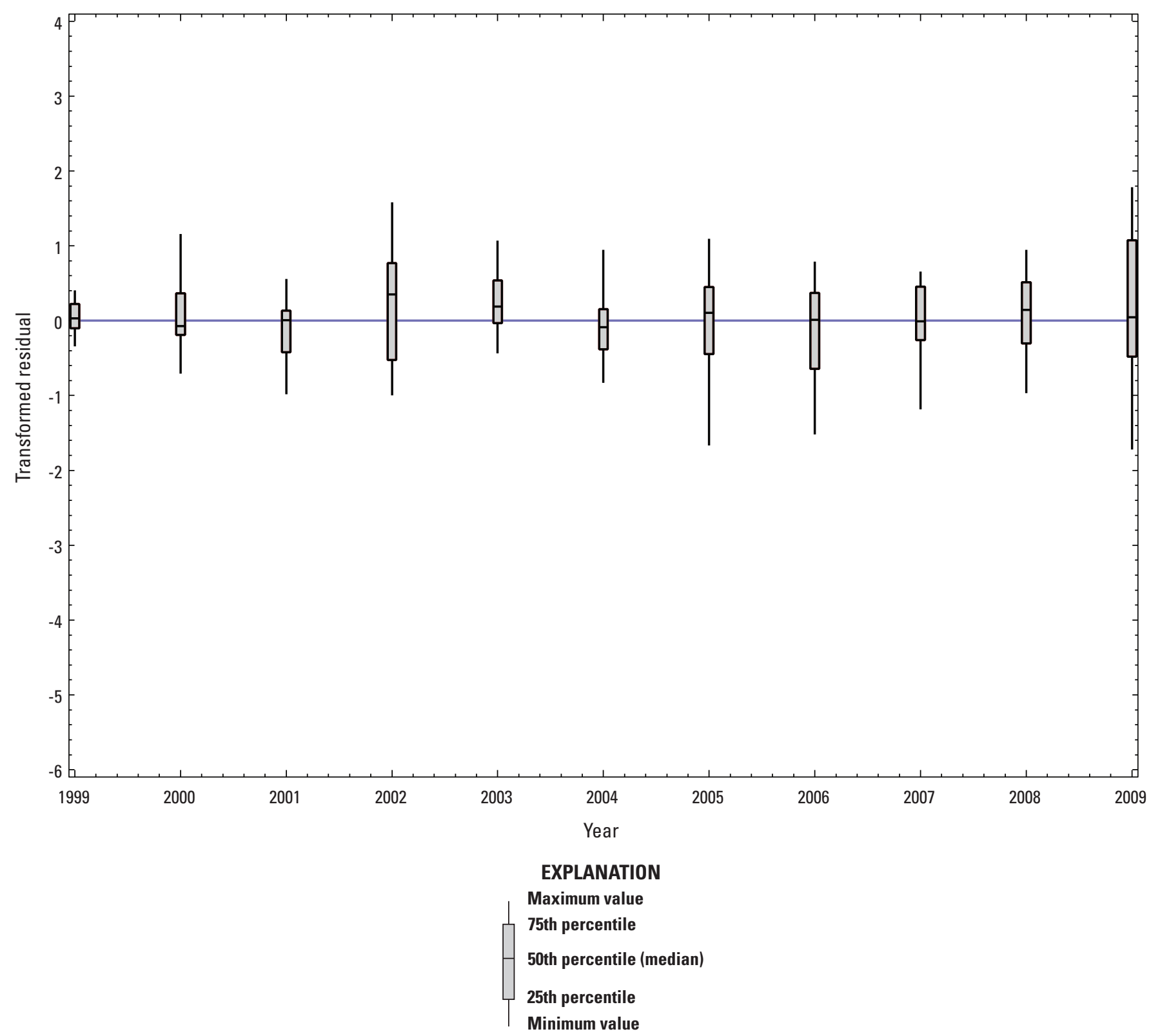

Figure 9. Transformed residuals, by water year, for monitored basins draining to Long Island Sound, water years 1999-2009.

“outer" confidence intervals (Mullaney and others, 2002, appendix 2). The average inner 90-percent confidence interval was \pm 19.5 percent and the average outer 90 -percent confidence interval was \pm 27.5 percent. Estimates of nitrogen yield from the GLS model for water year 2009 demonstrate, as an example, the inner and outer confidence intervals graphically in figure 11. Additional error, unaccounted for by these confidence intervals, could be present in the estimates because of the increased uncertainty of streamflow estimated using surrogate streamflow stations in the regression model input. Output information from the GLS regression model is in appendix 2 .

\section{Combined Estimates of Total Nitrogen Loads From Tributaries to Long Island Sound}

Nitrogen loads to Long Island Sound from tributaries were summed for each major basin represented by the Long Island Sound management zones (New York State Department of Environmental Conservation and Connecticut Department of Environmental Protection, 2000) shown in figure 12. The sum includes the loads from the farthest downstream monitoring stations calculated by using LOADEST, and the loads estimated by multiplying the estimated nitrogen yields from the unmonitored areas by the drainage area of each 
Table 6. Generalized least squares (GLS) estimates of model coefficients and standard errors, with asymptotically valid t-statistics and $p$-values.

$[<$, less than; na, not applicable]

\begin{tabular}{|c|c|c|c|c|c|}
\hline Transformed variable & Units & $\begin{array}{l}\text { Parameter } \\
\text { estimate }\end{array}$ & $\begin{array}{l}\text { Standard } \\
\text { error }\end{array}$ & t-statistic & $p$-value \\
\hline Intercept & Dimensionless & $-1,510$ & 224 & -6.75 & $<.0001$ \\
\hline Cultivated crops & Percent & 205.0 & 63.8 & 3.22 & 0.0015 \\
\hline $\begin{array}{l}\text { SPARROW (yield from wastewater-treatment } \\
\text { facilities outside of Connecticut) }\end{array}$ & $\begin{array}{l}\text { Pounds per square mile } \\
\text { per year }\end{array}$ & 1.51 & 0.18 & 8.23 & $<.0001$ \\
\hline Annual mean runoff & Inches & 99.9 & 5.04 & 19.8 & $<.0001$ \\
\hline Indicator for station 01184490 & Dimensionless & 8,940 & 1,370 & 6.51 & $<.0001$ \\
\hline
\end{tabular}

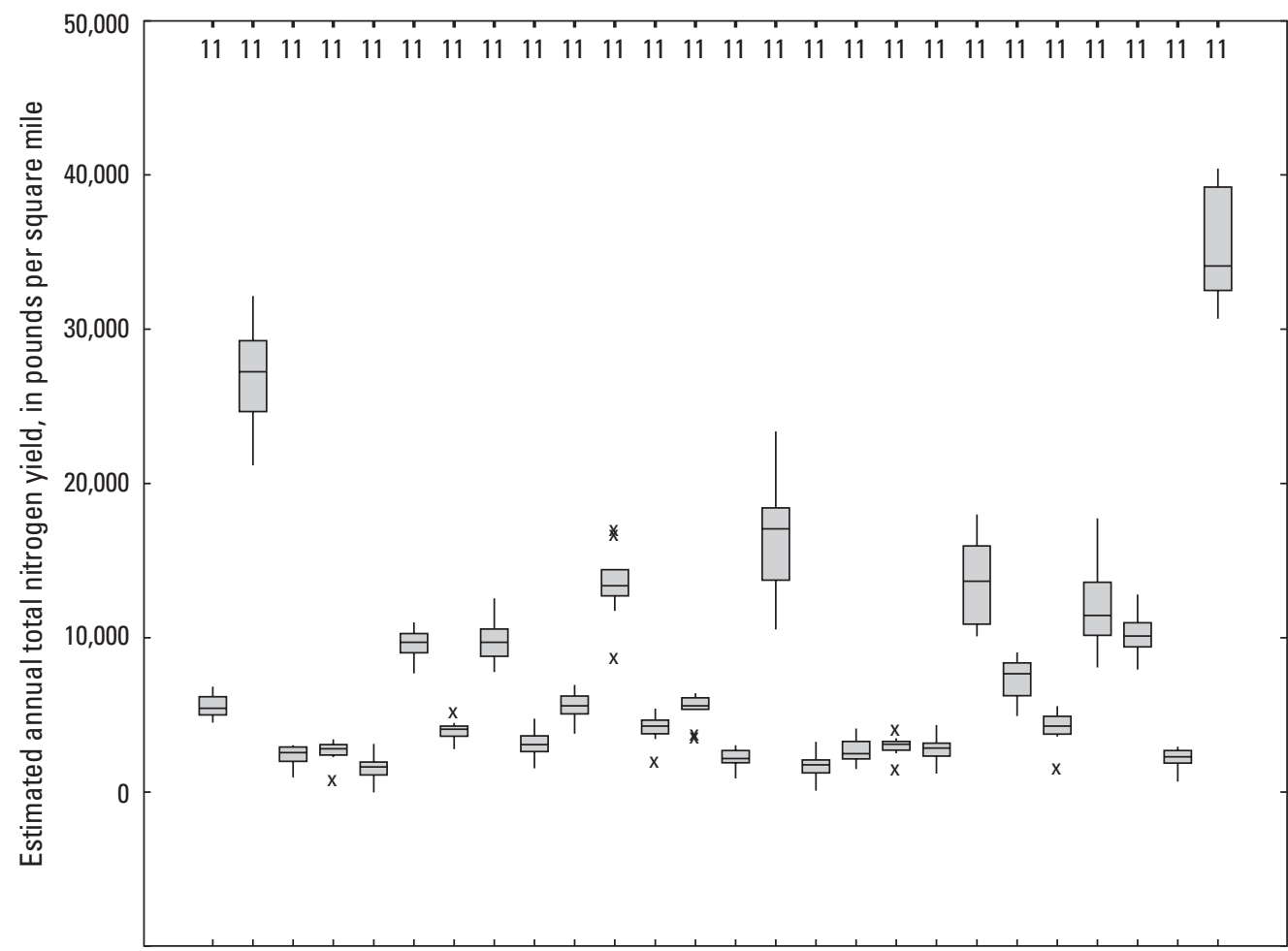

\section{EXPLANATION}

11 Number of values

Largest value within 1.5 times

interquartile range above

75th percentile

75th percentile

50th percentile

(median)

25th percentile

Interquartile range

Smallest value within 1.5 times interquartile range below 25th percentile

$x$ Outside value - Value is greater than 1.5 and less than 3 times the interquartile range beyond either end of the box

Figure 10. Boxplots showing distribution of estimated annual total nitrogen yield for unmonitored basins draining to Long Island Sound. 


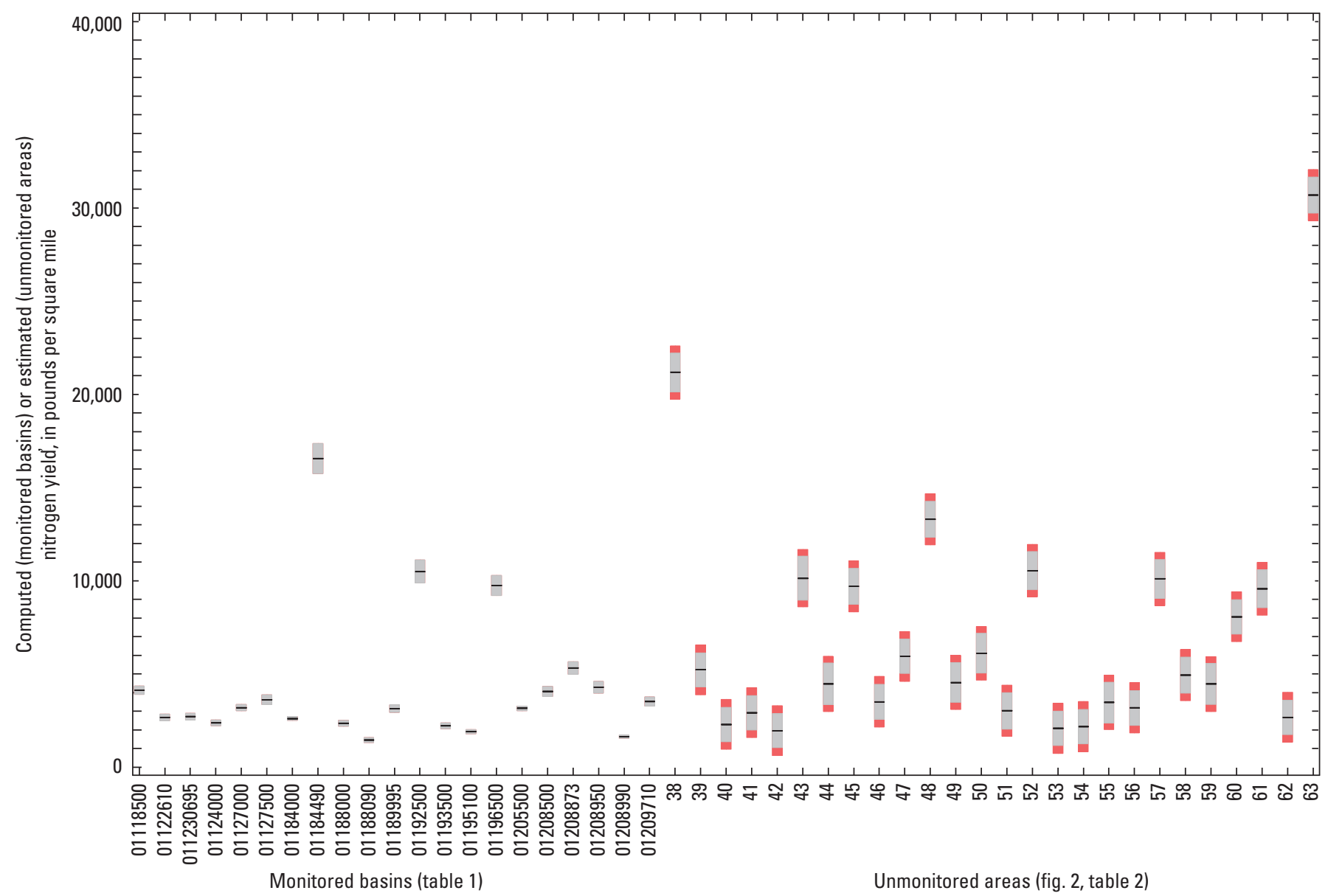

Site Identifier (fig. 2; tables 1-2)

EXPLANATION

- Outer 90-percent confidence interval Inner 90-percent confidence interval

Computed or estimated total nitrogen yield

Figure 11. Computed or estimated nitrogen yields and confidence intervals for monitored and unmonitored basins draining to Long Island Sound, water year 2009.

unmonitored area. The estimated total nitrogen load from the study area (excluding the Pawcatuck River Basin, which does not drain to Long Island Sound) ranged from a low of 37 million pounds (Mlb) in water year 2002 (a dry year) to $67 \mathrm{Mlb}$ (fig. 13; sum of zones in table 7) in water year 2006 (a wet year). Nitrogen loads from the monitored area above the fall-line stations ranged from 64 to 75 percent of the total nitrogen load from the study area. The nitrogen load from the monitored areas was dominated by the Connecticut River at Thompsonville, Conn. (station 01184000), near the border with Massachusetts, which represented 58 to 69 percent of the computed load from the monitored areas and 37 to 50 percent of the estimated nitrogen load from the study area.

Loads appear to have increased slightly during the study period (fig. 13), even though there were substantial decreases in nitrogen loads from WWTFs. As noted earlier in this report, this apparent increase is likely due to higher than normal streamflows and runoff during most of the study period (fig. 3).

Nitrogen loads were calculated for several basins at or near the border between Massachusetts and Connecticut (table 8), including the Housatonic River near Ashley Falls, Mass. (01198125); the Connecticut River at Thompsonville, Conn. (01184000); the Quinebaug River at Quinebaug, Conn. (01124000); and the French River at N. Grosvenordale, Conn. (01125100). Data from these stations for the available water years provide computed total nitrogen loads entering Connecticut from Massachusetts, with the exception of the Farmington River Basin where there is no monitoring station at the border. Computed nitrogen loads from these four stations ranged from 27.3 to $29.4 \mathrm{Mlb}$ for water years 2008 and 2009 (the only years with data for all sites; table 8), representing 52 to 54 percent of the estimated load to Long Island Sound from the study area. 


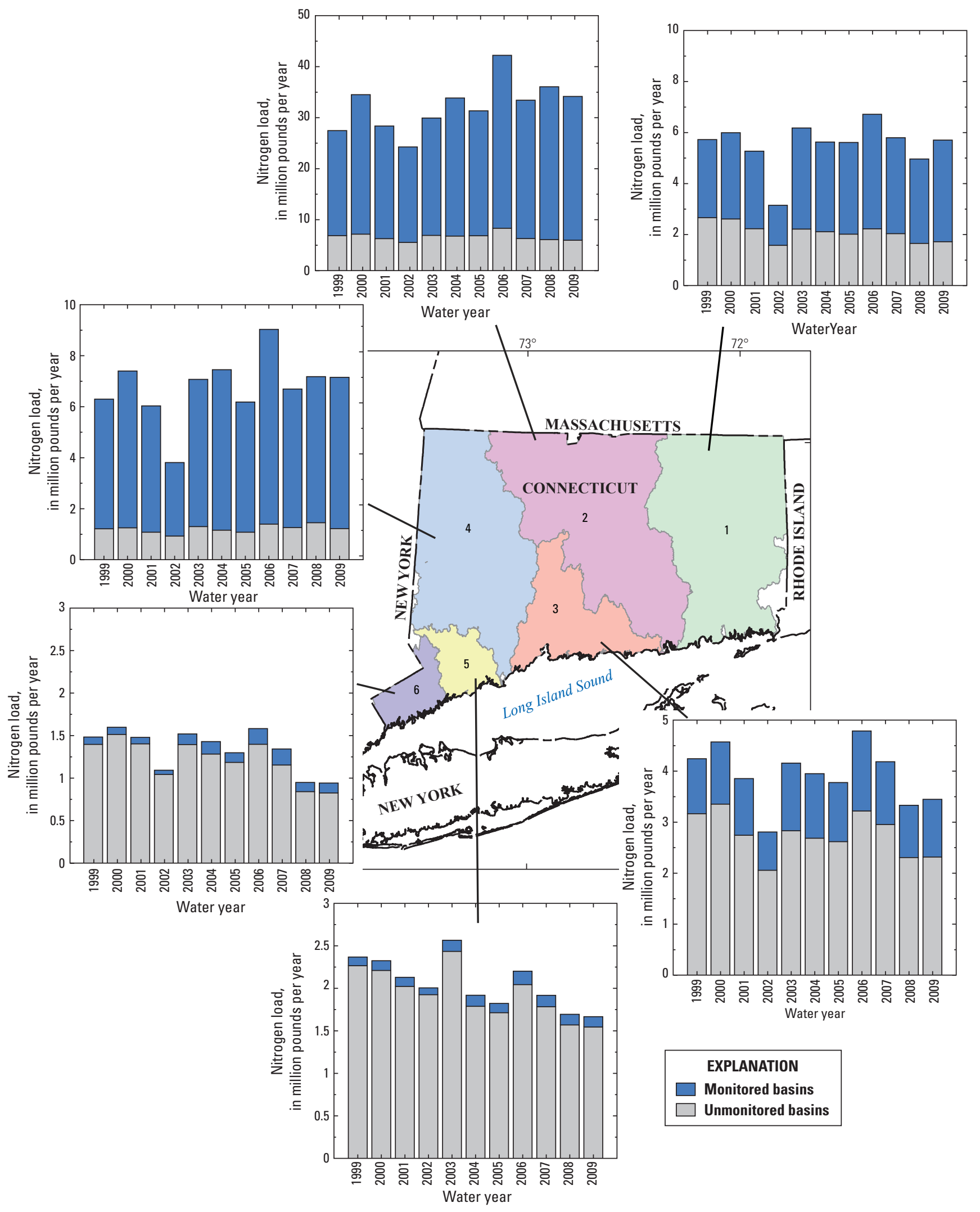

Figure 12. Long Island Sound management zones for nitrogen and estimated loads from monitored and unmonitored areas draining to Long Island Sound, water years 1999-2009. (Management zones in this report include the loads from upstream areas north of Connecticut.) 


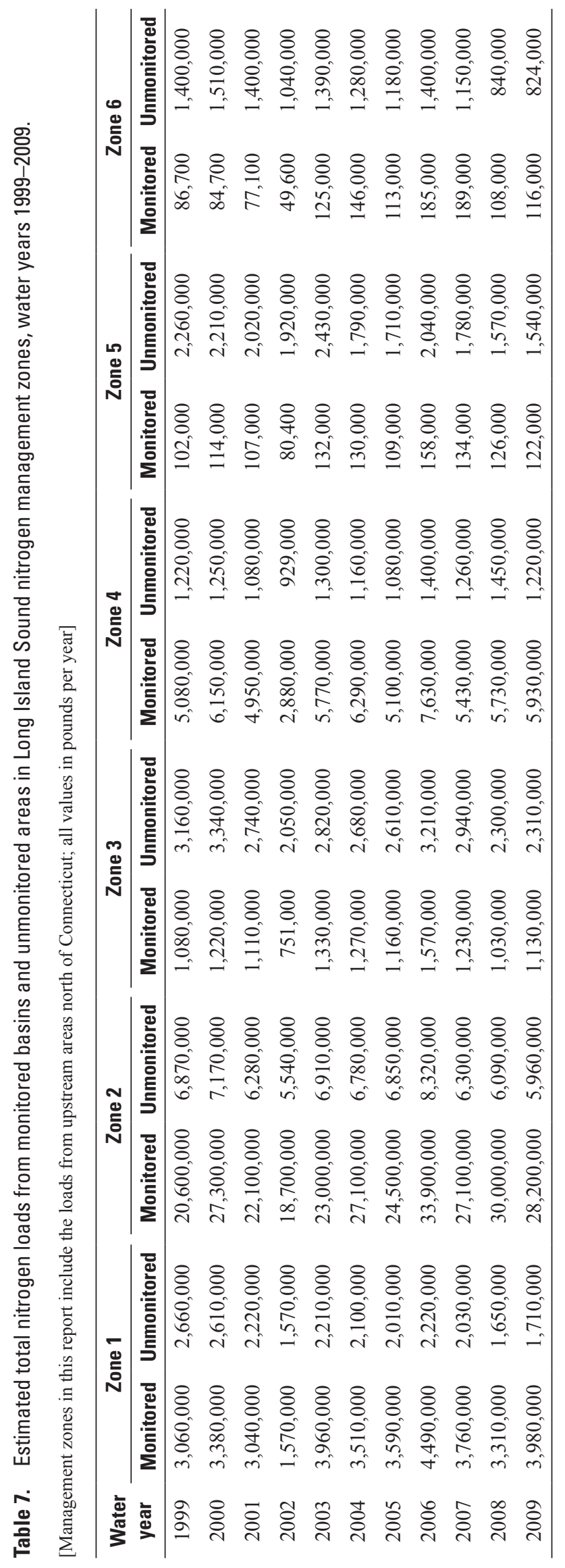




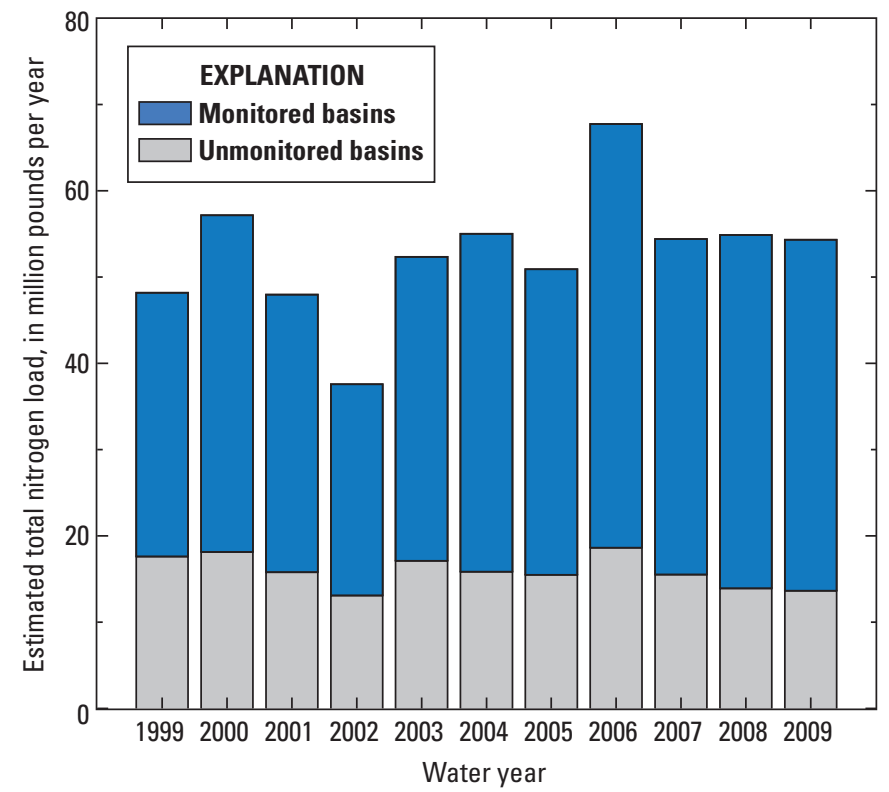

Figure 13. Estimated total nitrogen loads for monitored and unmonitored areas draining to Long Island Sound, water years 1999-2009.

Table 8. Computed nitrogen loads for state-border monitoring stations and percent of nitrogen load contributed to the Long Island Sound management zones, water years 1999-2009.

[Percent is the portion of the nitrogen load from the management zone. --, no data]

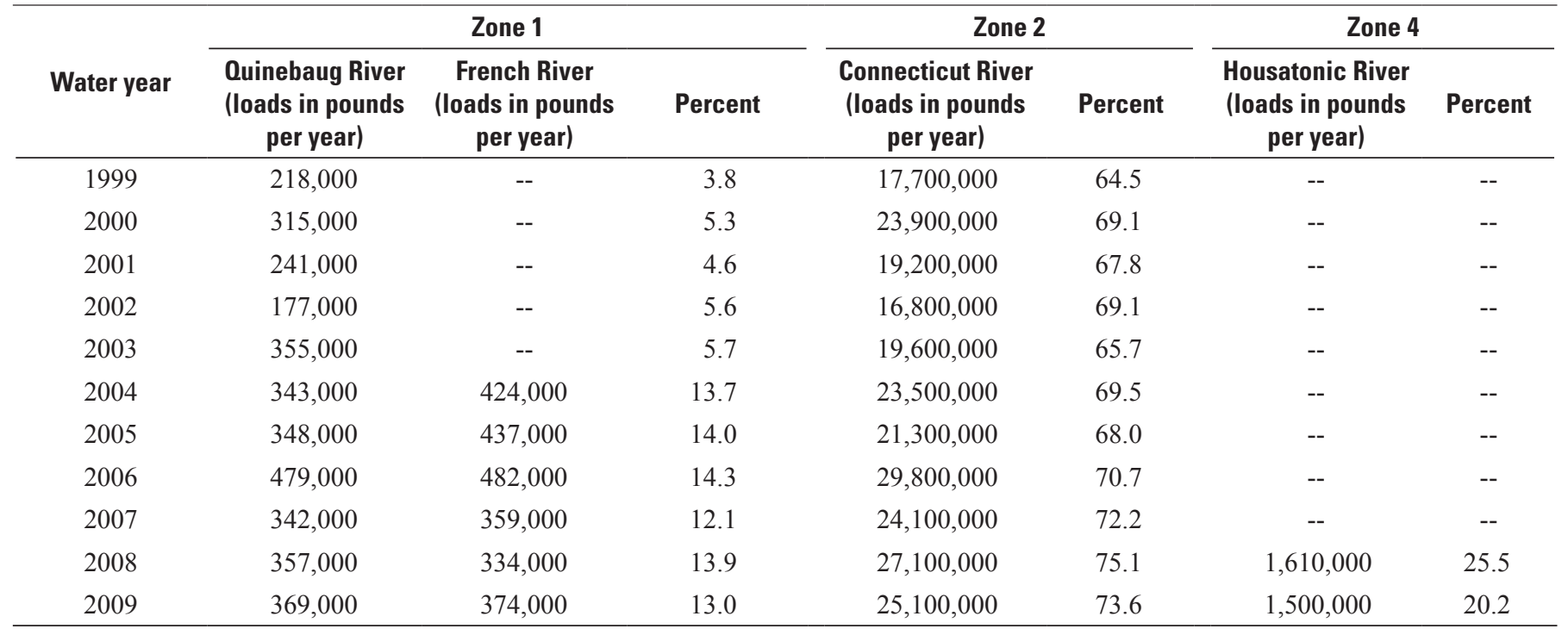




\section{Summary}

An assessment of total nitrogen loads from Connecticut to Long Island Sound for water years 1999-2009 was conducted. Data were analyzed to evaluate changes in nitrogen loads relative to nitrogen management efforts that have been ongoing in Connecticut and New York with a goal to reduce nitrogen loads by 58.5 percent by 2014 . As a result of management of point sources of nitrogen in Connecticut, annual nitrogen loads from municipal wastewater-treatment facilities declined by as much as 2 million pounds per year (Mlb/yr) in basins upstream from U.S. Geological Survey (USGS) monitoring stations and by as much as $5.8 \mathrm{Mlb} / \mathrm{yr}$ in basins downstream from USGS monitoring stations.

This assessment was based on an analysis of total nitrogen concentrations and continuous streamflow data from 37 water-quality monitoring stations in or near the Long Island Sound watershed. Data were collected from 4 to 22 times per year and for periods of 2 to 14 years. Nitrogen loads at monitoring stations were computed by using the computer program LOADEST, a regression model that incorporates the relation of constituent concentration to streamflow, time, and season.

Nitrogen yields at monitoring stations in the study were typically less than 2,000 pounds per square mile per year $\left(\mathrm{lb} / \mathrm{mi}^{2} / \mathrm{yr}\right)$ in basins that were dominated by forested land. Median nitrogen yields from urbanized basins with no major wastewater-treatment facilities were as high as $5,600 \mathrm{lb} / \mathrm{mi}^{2} / \mathrm{yr}$, whereas median nitrogen yields from urbanized basins with major wastewater-treatment facilities were as high as $13,100 \mathrm{lb} / \mathrm{mi}^{2} / \mathrm{yr}$. The highest yields were from the Broad Brook Basin, in north central Conn. with a median nitrogen yield of $14,600 \mathrm{lb} / \mathrm{mi}^{2} / \mathrm{yr}$.

Median nitrogen yields for water years 1999-2009 were compared with nitrogen yields for water years 1988-98 to determine whether there were any substantial changes. Nitrogen yields generally were similar for the two periods for most stations. Stations with the most obvious improvements include the Naugatuck River at Beacon Falls, Conn.; Quinnipiac River at Wallingford, Conn.; and Hockanum River near East Hartford, Conn. With major declines in nitrogen loads from wastewater-treatment facilities in Connecticut, more apparent changes were expected. Streamflow was higher than normal, however, during much of the study period, and consequently, nitrogen loads from nonpoint sources were greater, potentially masking improvements.

Total nitrogen loads from 26 unmonitored coastal areas during 1999 through 2009 were estimated using a generalized least squares (GLS) multiple-linear regression model coupled with an analysis of error components. The regression model related computed annual yield of nitrogen from monitored basins to basin characteristics. The model also was used to estimate nitrogen loads for missing years from fall-line stations with fewer than 11 years of data. Explanatory variables that were statistically significant in the GLS model include percentage of developed land, percentage of row crops, point-source yield of nitrogen from Connecticut wastewater facilities, annual mean runoff, and point-source nitrogen yield estimated for parts of the watershed north of the Connecticut border with Massachusetts. Estimated nitrogen yields from the unmonitored areas ranged from $1,630 \mathrm{lb} / \mathrm{mi}^{2} / \mathrm{yr}$ to $35,400 \mathrm{lb} / \mathrm{mi}^{2} / \mathrm{yr}$. The average inner and outer 90 -percent confidence intervals of the yield predictions were \pm 19.5 and \pm 27.5 percent, respectively.

Load calculations using data from the farthest downstream monitoring stations were summed with estimates for the unmonitored areas for a combined estimate of the total nitrogen load from the study area for water years 1999-2009. The estimated total nitrogen load from the study area ranged from $38 \mathrm{Mlb} / \mathrm{yr}$ (water year 2002) to $68 \mathrm{Mlb} / \mathrm{yr}$ (water year 2006). Loads increased slightly during the study period, but any increases are likely due to higher than normal streamflows during most of the study period. The loads calculated or estimated for the monitored areas upstream from the fall-line stations represented 63 to 74 percent of the estimated load of total nitrogen from the study area, with the estimates from the unmonitored areas representing the remainder. Nitrogen loads at stations on the major tributaries (excluding the Farmington River) that cross the Connecticut border with Massachusetts represented 52 to 54 percent of the estimated nitrogen load from the study area to Long Island Sound.

\section{References Cited}

Cohn, T.A., 1988, Adjusted maximum likelihood estimation of the moments of lognormal populations from type I censored samples: U.S. Geological Survey Open-File Report 88-350, 34 p. (Also available at http://pubs.usgs.gov/of/1988/0350/ report.pdf.)

Cohn, T.A., Gilroy, E.J., and Baier, W.G., 1992, Estimating fluvial transport of trace constituents using a regression model with data subject to censoring, in Proceedings of the Section on Statistics and the Environment, joint statistical meeting, Boston, Massachusetts, August 9-13, 1992: Alexandria, Virginia, American Statistical Association, p. 142-151.

Connecticut Department of Environmental Protection, 2001, Environmental compliance in Connecticut: Hartford, Connecticut, Connecticut Department of Environmental Protection, February 2, 50 p., accessed August 14, 2012, at http://www.ct.gov/dep/lib/dep/enforcement/ reports/2000annualreport.pdf. 
Connecticut Department of Environmental Protection, 2010, Connecticut's nitrogen credit exchange-An incentivebased water quality trading program: Hartford, Connecticut, Connecticut Department of Environmental Protection, 10 p., accessed April 9, 2013, at http://www.ct.gov/deep/lib/deep/ water/lis_water_quality/nitrogen_control_program/water_ quality_trading_summary_2010.pdf.

Deacon, J.R., Smith, T.E., Johnston, C.M., Moore, R.B., Weidman, R.M., and Blake, L.J., 2006, Assessment of total nitrogen in the Upper Connecticut River Basin in New Hampshire, Vermont, and Massachusetts, December 2002-September 2005: U.S. Geological Survey Scientific Investigations Report 2006-5144, 89 p.

Fishman, M.J., ed., 1993, Methods of analysis by the U.S. Geological Survey National Water Quality LaboratoryDetermination of inorganic and organic constituents in water and fluvial sediments: U.S. Geological Survey OpenFile Report 93-125, 217 p. (Also available at http://pubs. usgs.gov/of/1993/0125/report.pdf.)

Homer, Collin, Dewitz, Jon, Fry, Joyce, Coan, Michael, Hossain, Nazmul, Larson, Charles, Herold, Nate, McKerrow, Alexa, VanDriel, J.N., and Wickham, James, 2007, Completion of the 2001 national land cover database for the conterminous United States: Photogrammetric Engineering and Remote Sensing, v. 73, no. 4, p. 337-341.

Lane, S.L., Flanagan, Sarah, and Wilde, F.D., 2003, Selection of equipment for water sampling (ver. 2.0): U.S. Geological Survey Techniques of Water-Resources Investigations, book 9, chap. A2, March 2003, accessed September 10, 2013, at http://pubs.water.usgs.gov/twri9A2/.

Long Island Sound Study, 1994, The comprehensive conservation and management plan: Long Island Sound Study, accessed April 9, 2013, at http:// longislandsoundstudy.net/wp-content/uploads/2011/10/ management_plan.pdf.

Long Island Sound Study, 2013, About the Long Island Sound study, accessed April 9, 2013, at http:// longislandsoundstudy.net/about/about-the-study/.

Maupin, M.A., and Ivahnenko, Tamara, 2011, Nutrient loadings to streams of the Continental United States from municipal and industrial effluent: Journal of the American Water Resources Association, v. 47, no. 5, p. 950-964.

McMahon, Gerard, Tervelt, Larinda, and Donehoo, William, 2007, Methods for estimating annual wastewater nutrient loads in the southeastern United States: U.S. Geological Survey Open-File Report 2007-1040, 81 p. (Also available at http://pubs.usgs.gov/of/2007/1040/.)
Moore, R.B., Johnston, C.M, Smith, R.A., and Milstead, Bryan, 2011, Source and delivery of nutrients to receiving waters in the northeastern and mid-Atlantic regions of the United States: Journal of the American Water Resources Association, v. 47, no. 5, p. 965-990.

Mullaney, J.R., 2007, Nutrient loads and ground-water residence times in an agricultural basin in northcentral Connecticut: U.S. Geological Survey Scientific Investigations Report 2006-5278, 45 p.

Mullaney, J.R., Schwarz, G.E., and Trench, E.C.T., 2002, Estimation of nitrogen yields and loads from basins draining to Long Island Sound, 1988-98: U.S. Geological Survey Water-Resources Investigations Report 02-4044, 84 p.

New York State Department of Environmental Conservation and Connecticut Department of Environmental Protection, 2000, A total maximum daily load analysis to achieve water-quality standards for dissolved oxygen in Long Island Sound: Albany, N.Y., New York State Department of Environmental Conservation and Hartford, Conn., Connecticut Department of Environmental Protection, 73 p. (Also available at http://longislandsoundstudy.net/ wp-content/uploads/2010/03/Tmdl.pdf.)

Patton, C.J., and Truitt, E.P., 2000, Methods of analysis by the U.S. Geological Survey National Water Quality Laboratory-Determination of ammonium plus organic nitrogen by a Kjeldahl digestion method and an automated photometric finish that includes digest cleanup by gas diffusion: U.S. Geological Survey Open-File Report 00-170, 31 p. (Also available at http://pubs.usgs.gov/ of/2000/0170/report.pdf.)

Rantz, S.E., and others, 1982a, Computation of discharge, v. 2 of Measurement and computation of streamflow: U.S. Geological Survey Water-Supply Paper 2175, p. 285-631.

Rantz, S.E., and others, 1982b, Measurement of stage and discharge, v. 1 of Measurement and computation of streamflow: U.S. Geological Survey Water-Supply Paper 2175, p. 1-284.

Runkel, R.L., Crawford, C.G., and Cohn, T.A., 2004, Load estimator (LOADEST) - A FORTRAN program for estimating constituent loads in streams and rivers: U.S. Geological Survey Techniques and Methods book 4, chap. A5, 69 p. (Also available at http://pubs.usgs.gov/tm/2005/ tm4A5/pdf/508final.pdf.)

Smith, T.E., Laursen, A.E., and Deacon, J.R., 2008, Nitrogen attenuation in the Connecticut River, northeastern USA; a comparison of mass balance and $\mathrm{N} 2$ production modeling approaches: Biogeochemistry, v. 87, p. 311-323. 
Trench, E.C.T., 2000, Nutrient sources and loads in the Connecticut, Housatonic, and Thames River Basins: U.S. Geological Survey Water-Resources Investigations Report 99-4236, 66 p.

U.S. Environmental Protection Agency, 2001, 2001 national land cover data: Multi-Resolution Land Characteristics Consortium, accessed February 1, 2010, at http://www.epa. gov/mrlc/nlcd-2001.html.

U.S. Geological Survey, 2006, Collection of water samples (ver. 2.0): U.S. Geological Survey Techniques of WaterResources Investigations, book 9, chap. A4, accessed May 6, 2013, at http://pubs.water.usgs.gov/twri9A4/.

U.S. Geological Survey, 2012, USGS waterwatch: U.S. Geological Survey, accessed April 12, 2013 at http:// waterwatch.usgs.gov/index.php?r=ct\&id=statesum.

Wilde, F.D., 2005, Preparations for water sampling: U.S. Geological Survey Techniques of Water-Resources Investigations, book 9, chap. A1, accessed September 10, 2013, at http://pubs.water.usgs.gov/twri9A1/.

Wilde, F.D., ed., [variously dated], Field measurements: U.S. Geological Survey Techniques of Water-Resources Investigations, book 9, chap. A6, accessed September 10, 2013, at http://pubs.water.usgs.gov/twri9A6/.

Wilde, F.D., ed., 2004, Cleaning of equipment for water sampling (ver. 2.0): U.S. Geological Survey Techniques of Water-Resources Investigations, book 9, chap. A3, accessed September 10, 2013, at http://pubs.water.usgs.gov/twri9A3/.

Wilde, F.D., Radtke, D.B., Gibs, Jacob, and Iwatsubo, R.T., eds., 2004-9, Processing of water samples (ver. 2.2): U.S. Geological Survey Techniques of Water-Resources Investigations, book 9, chap. A5, accessed September 2013, at http://pubs.water.usgs.gov/twri9A5/. 
This page has been left blank intentionally. 


\section{Appendix 1}

Table 1-1. Load estimates and regression model input data

\section{Appendix 2}

Table 2-1. Regression model yield estimates for unmonitored areas draining to Long Island Sound

\section{Appendix 3}

Table 3-1. Annual total nitrogen loads from wastewater-treatment facilities in Connecticut, 1999-2009

Figure 3-1. Map showing location of wastewater-treatment facilities in Connecticut 


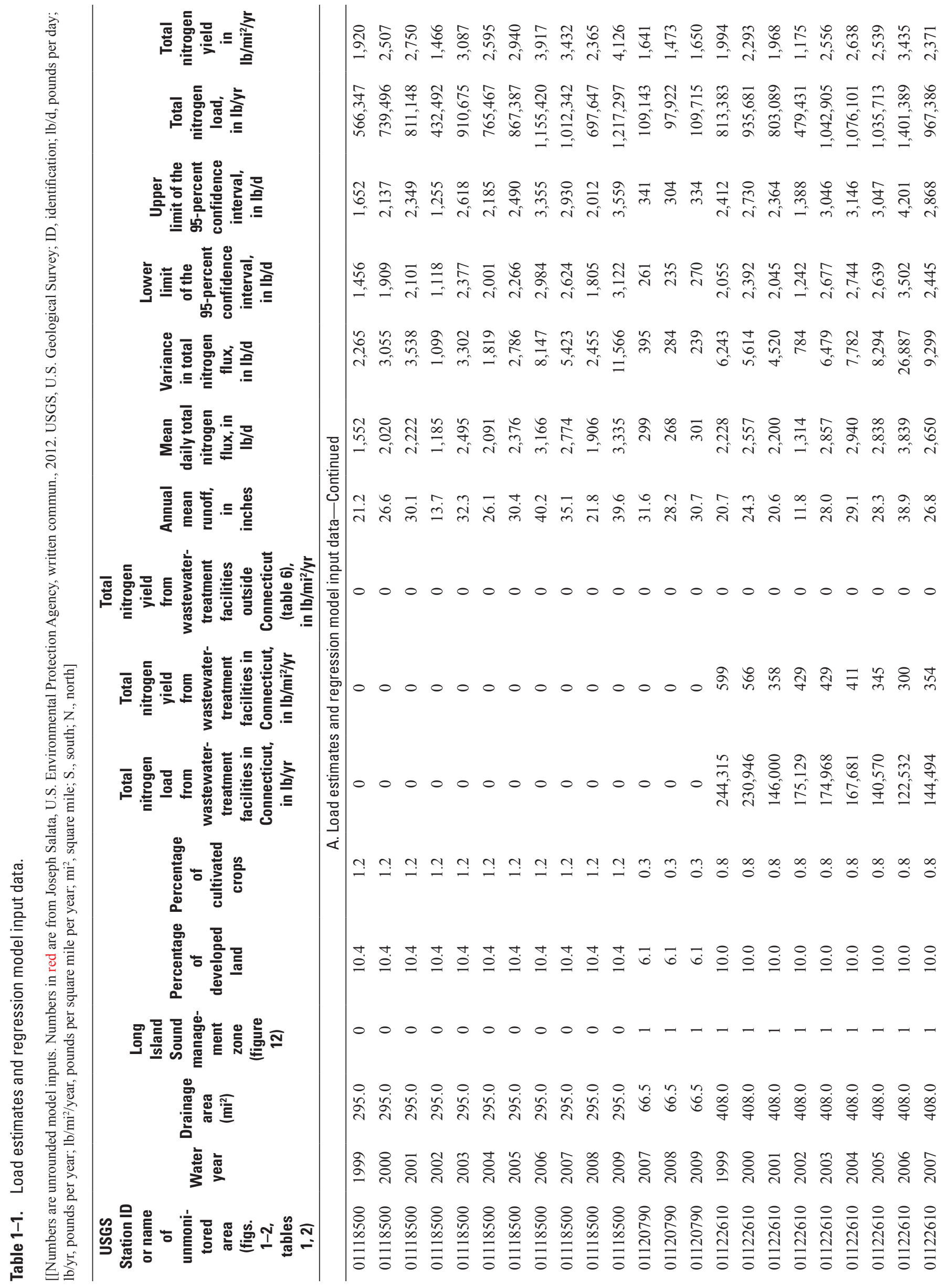




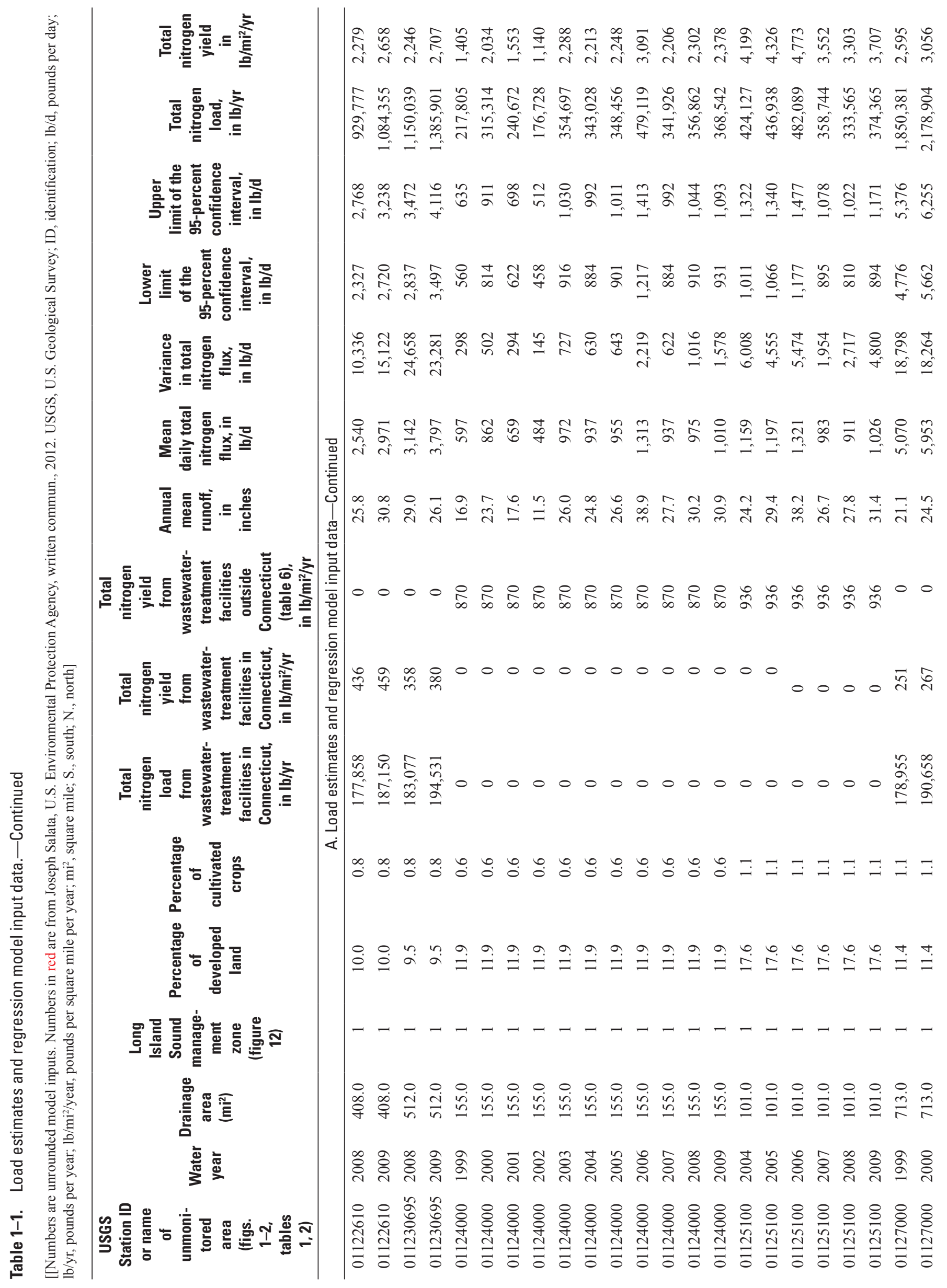




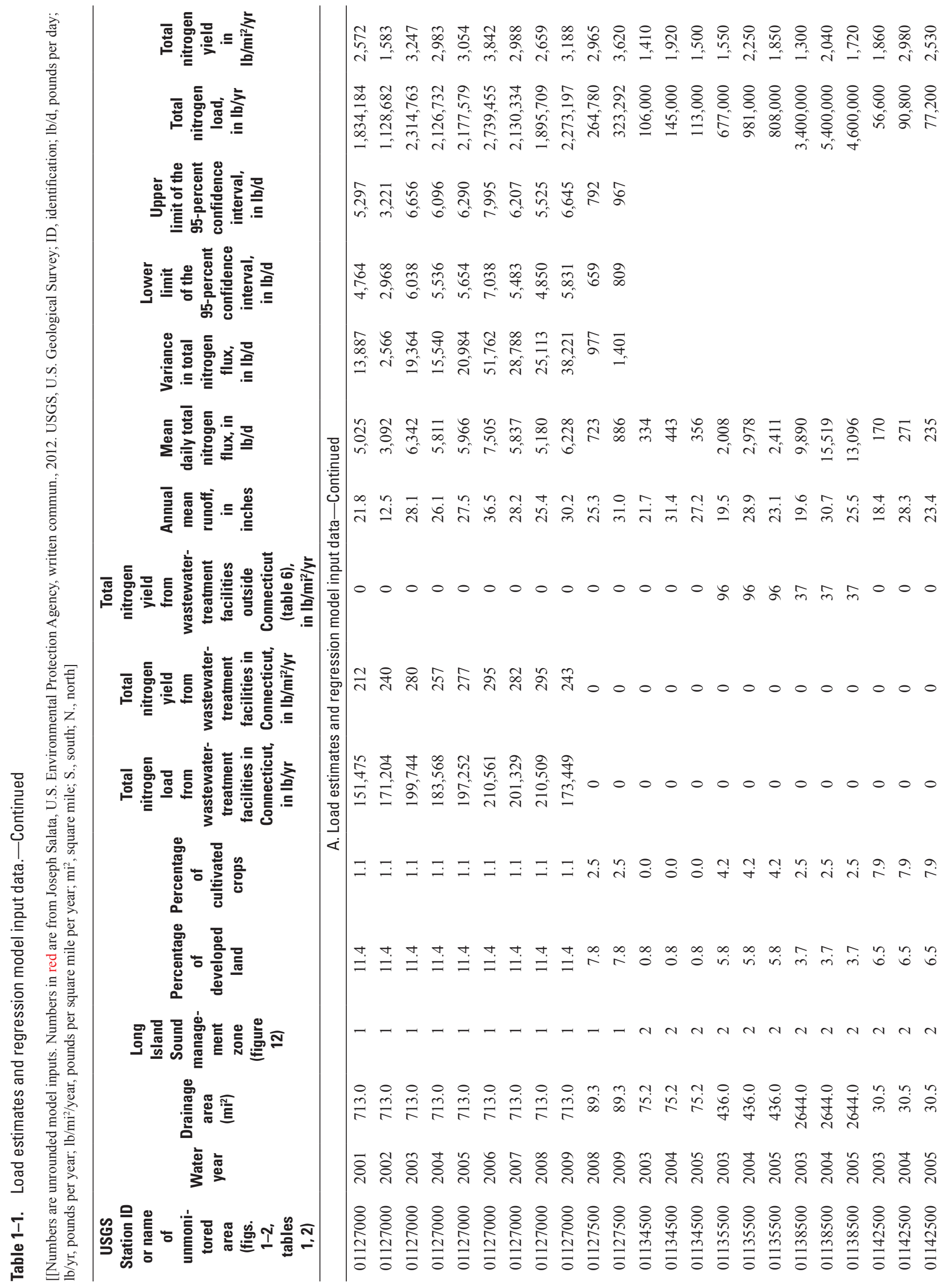




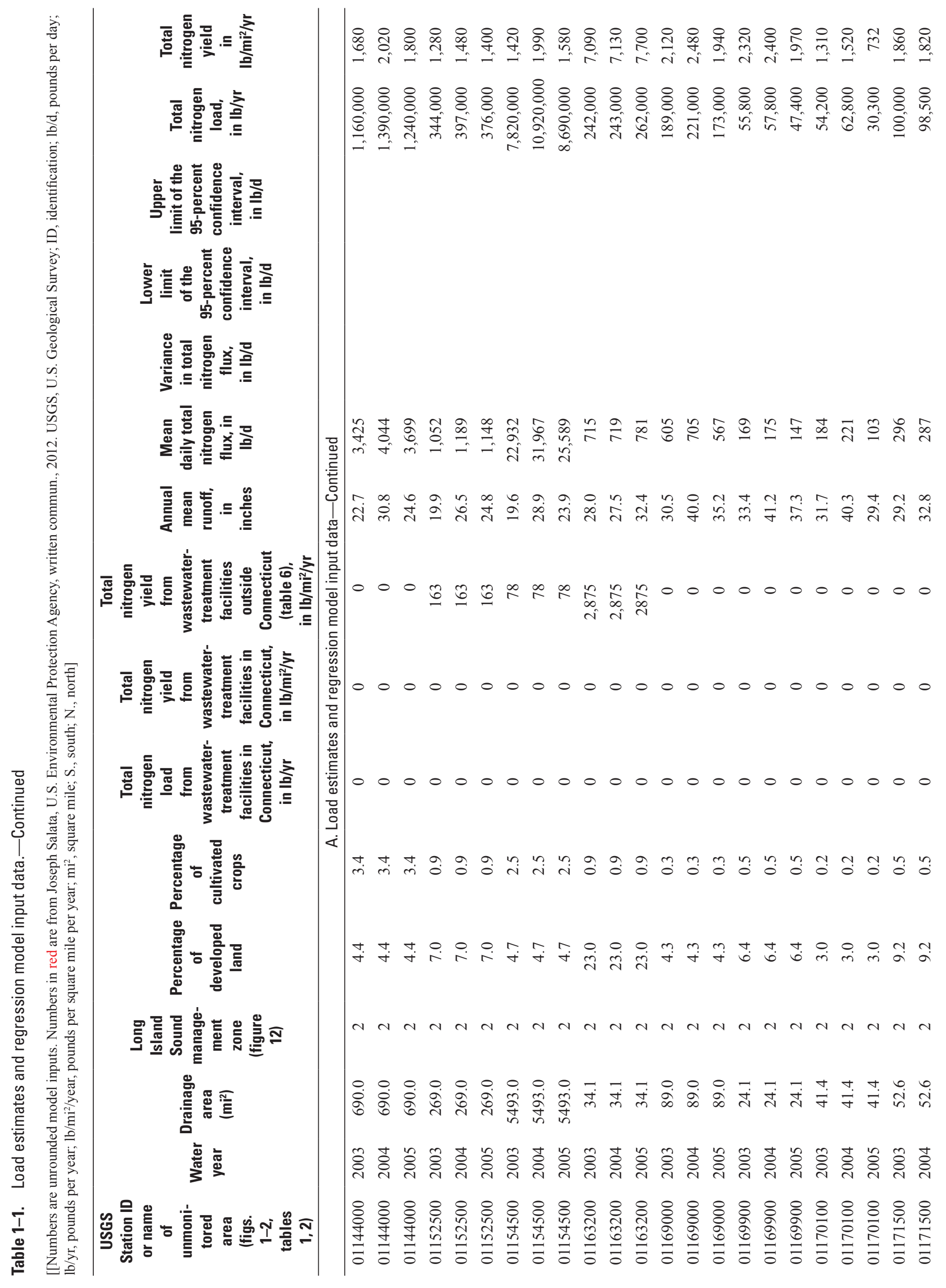




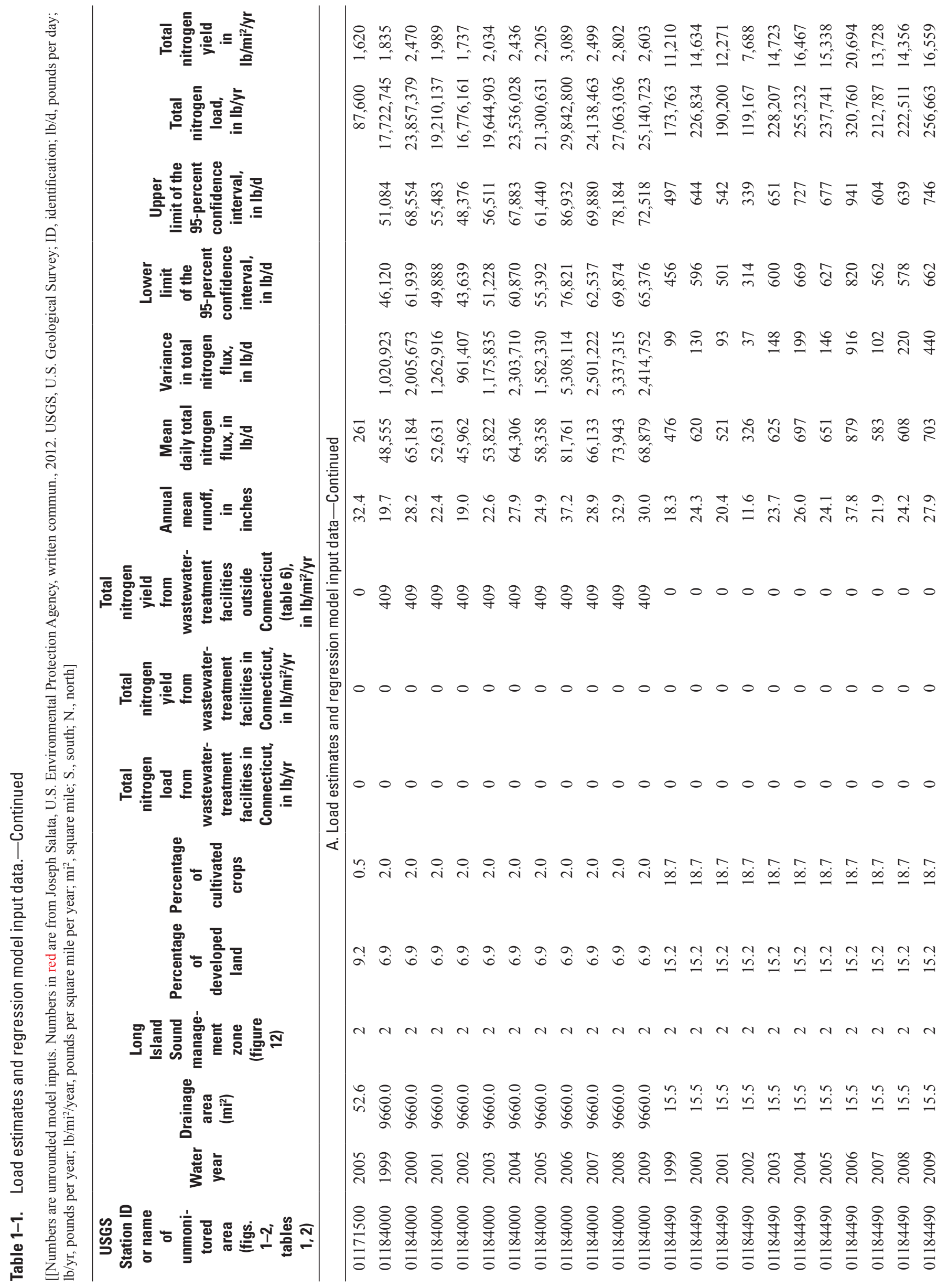




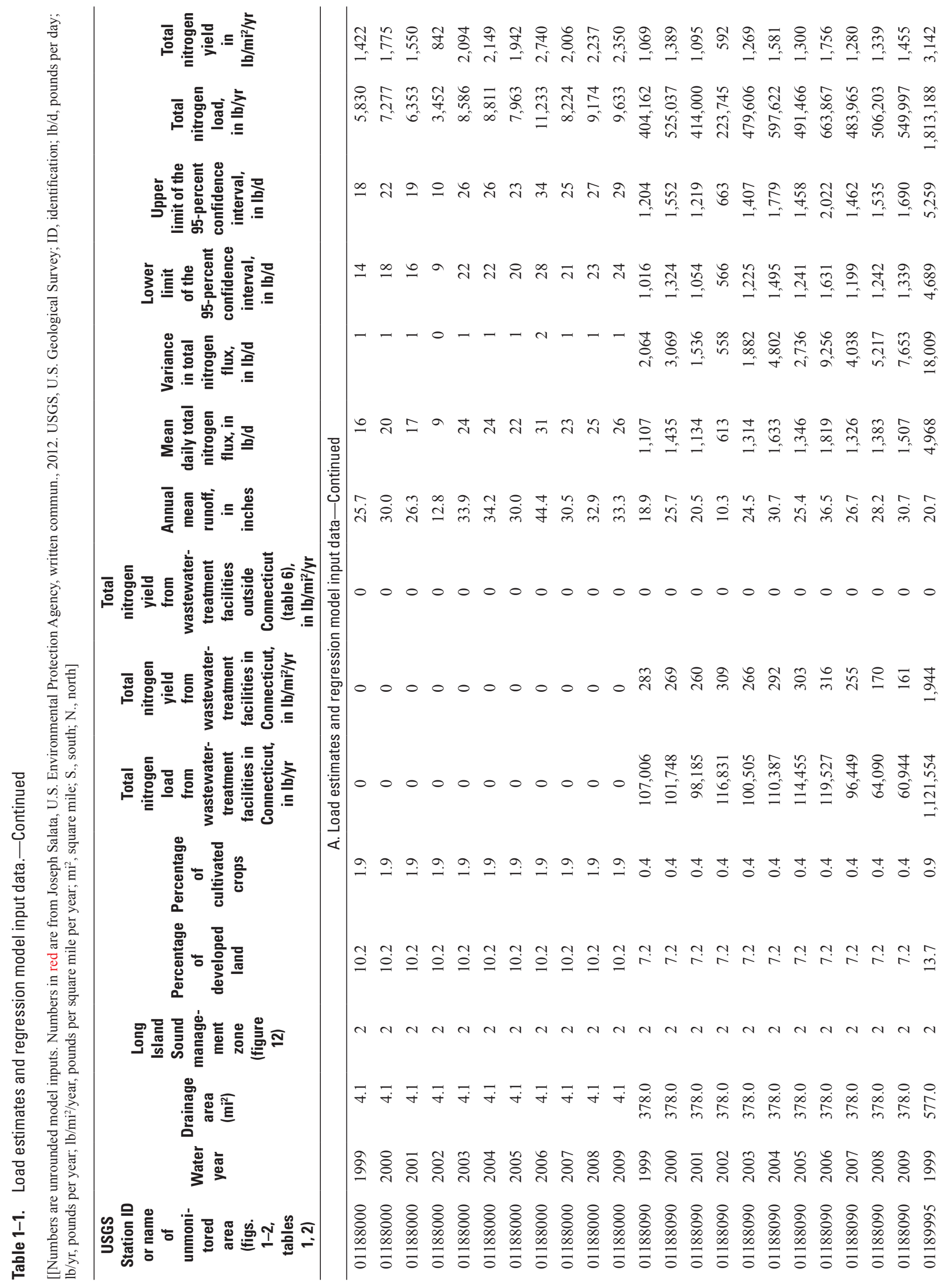




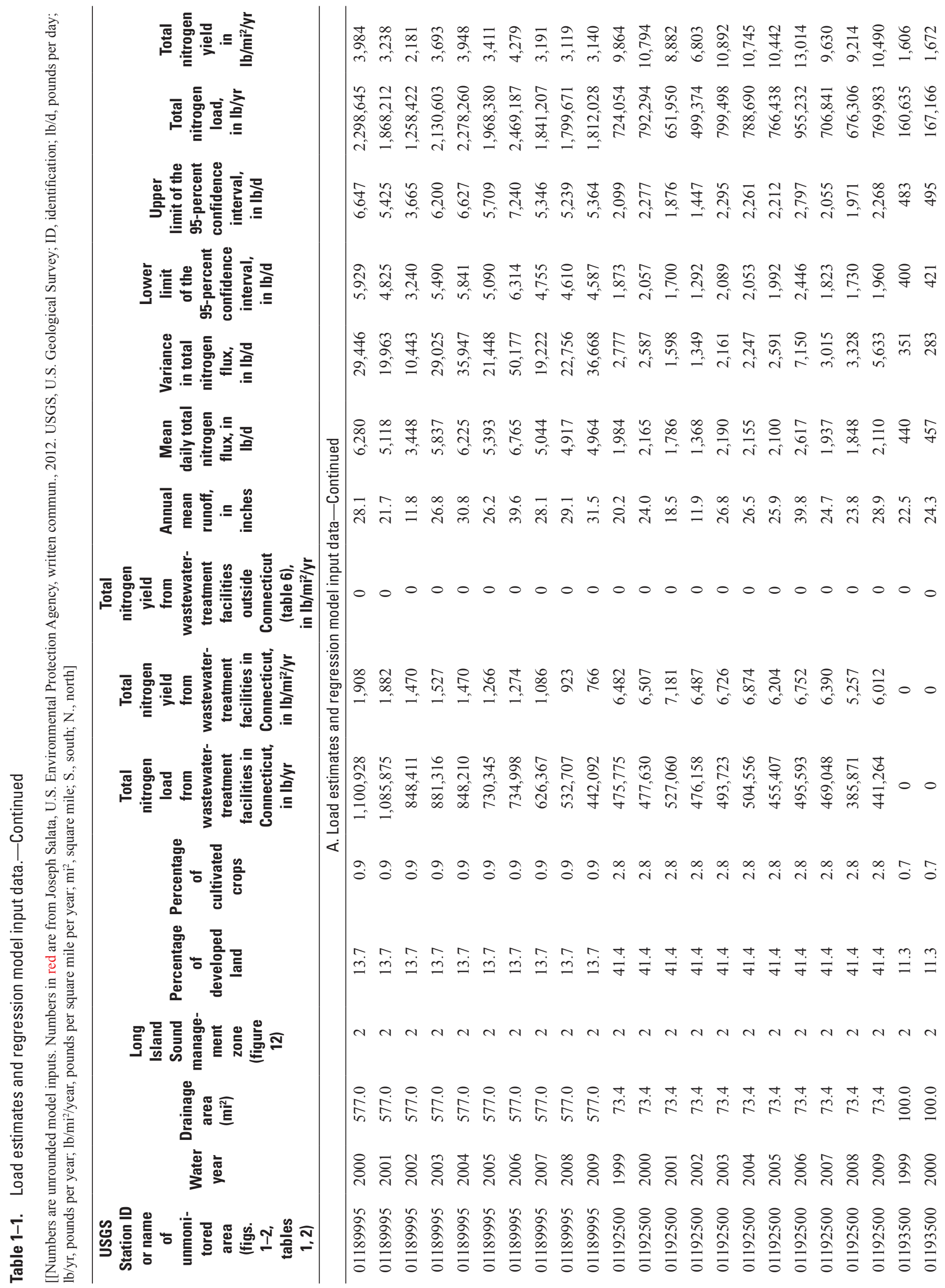




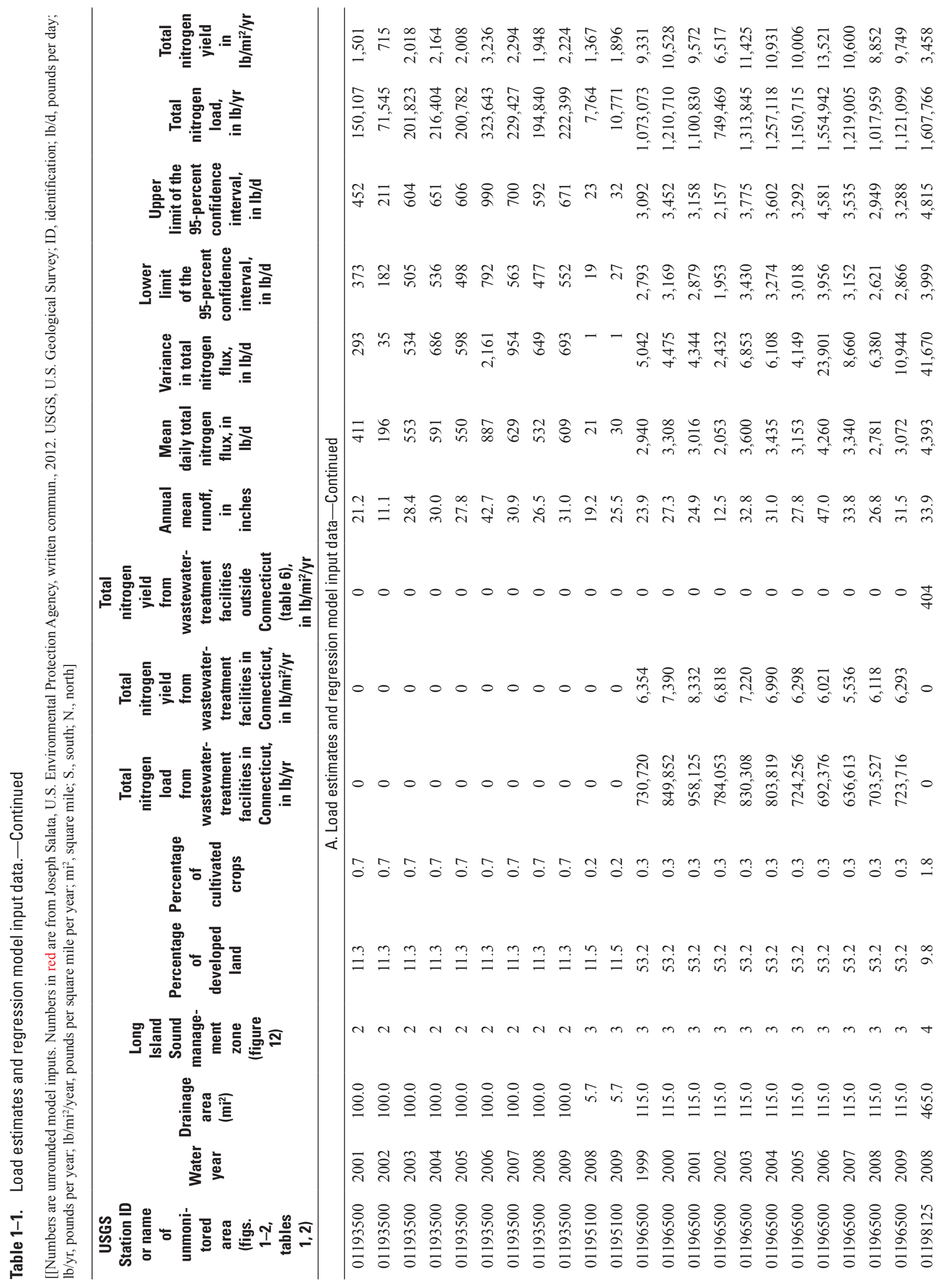




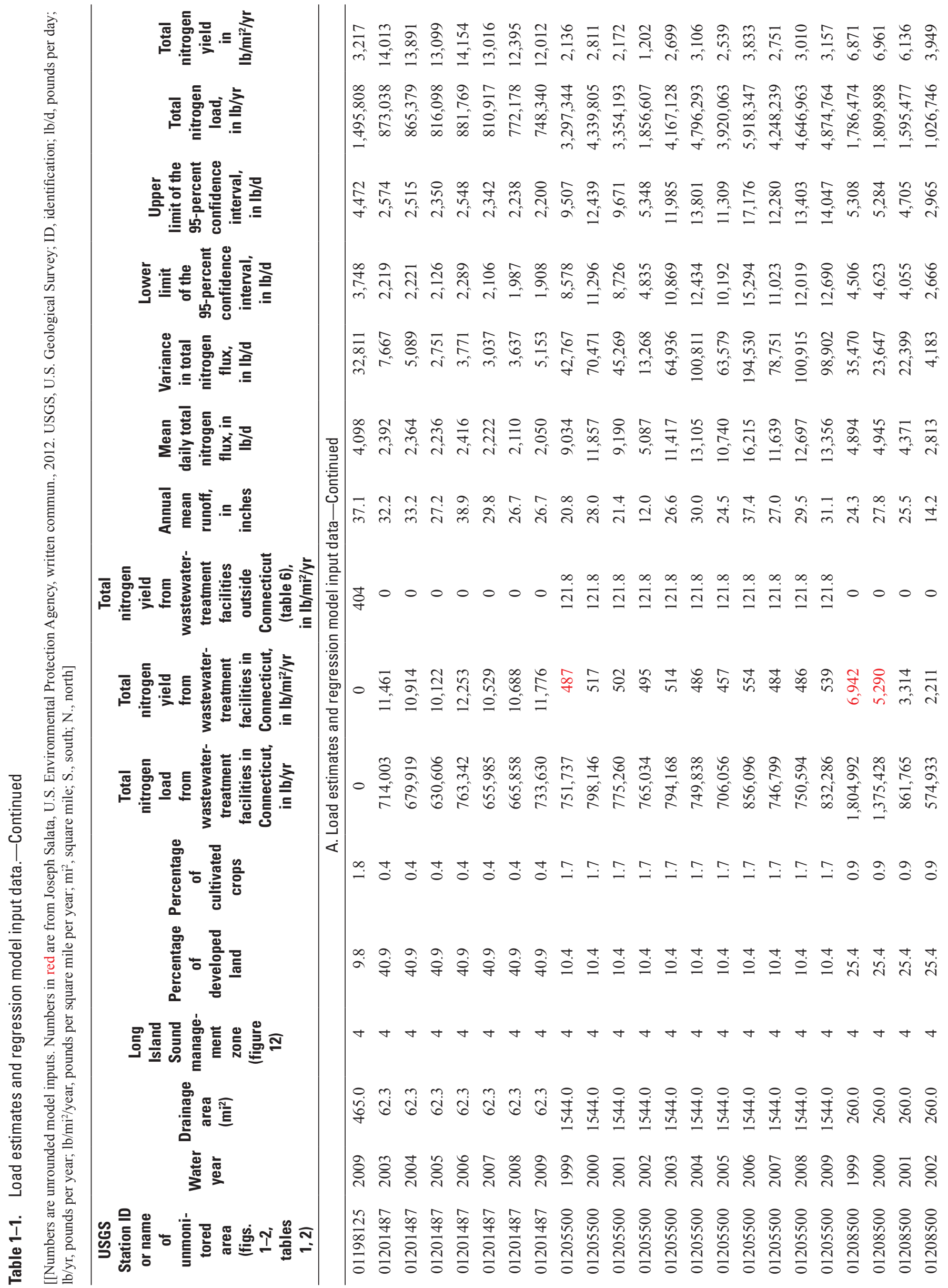




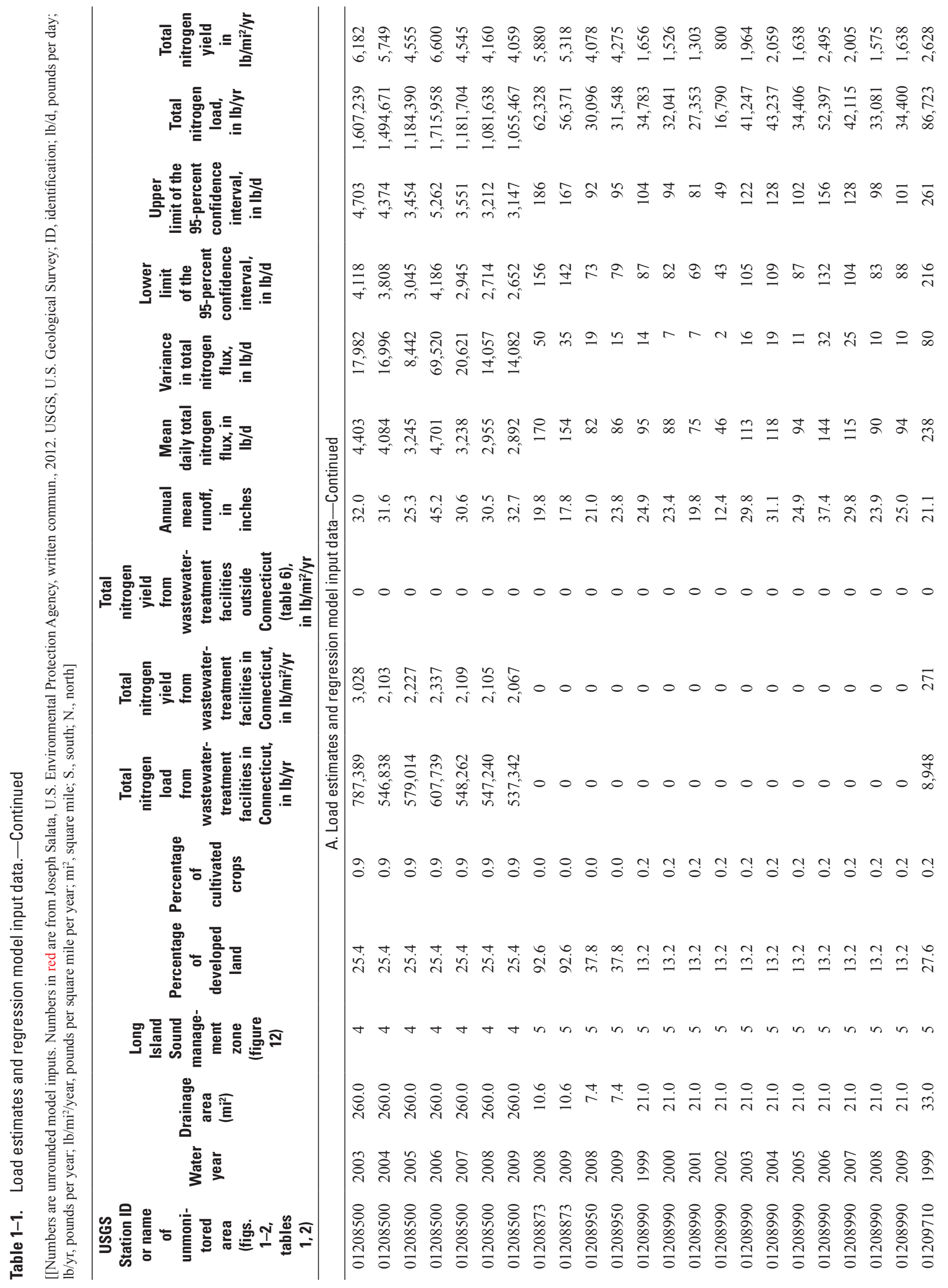




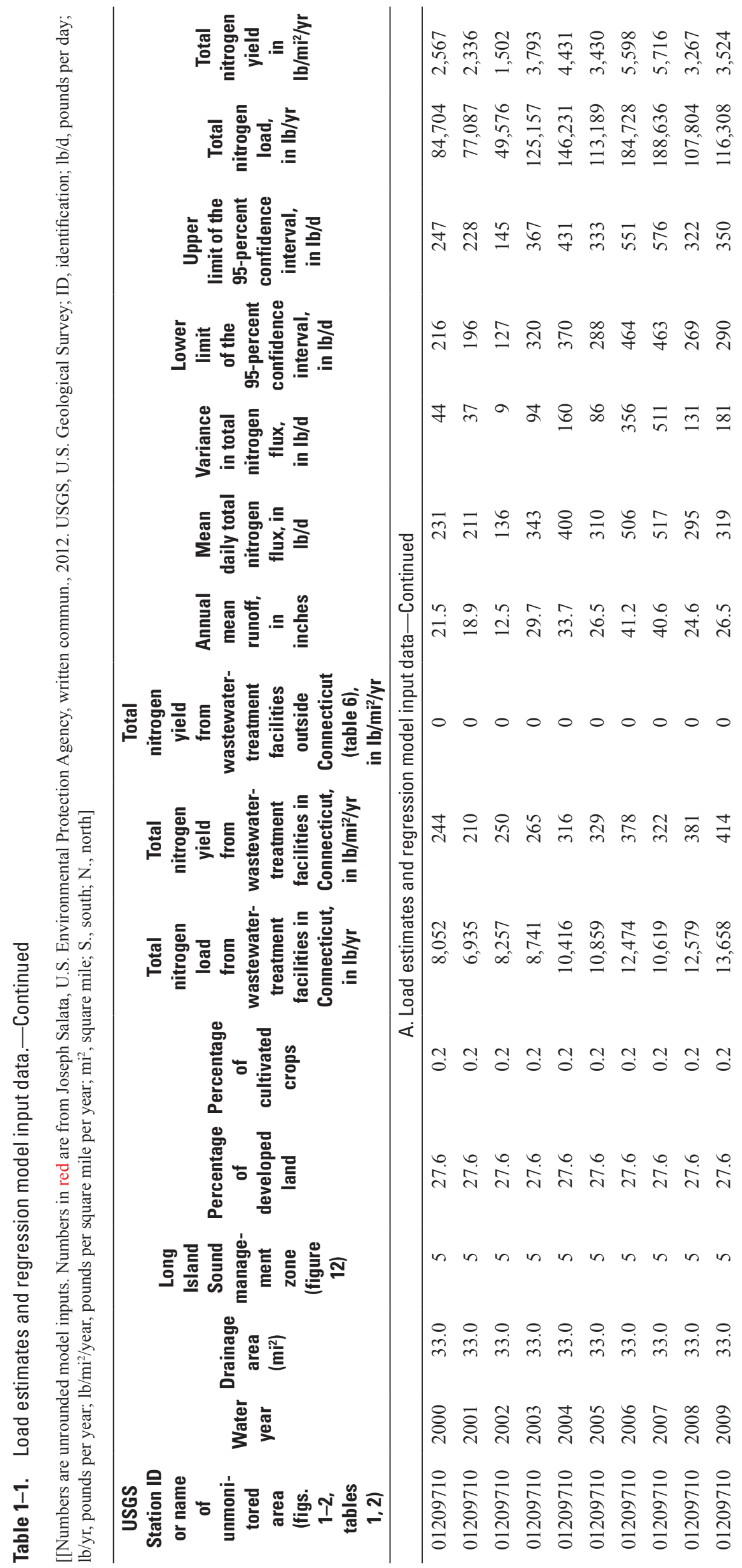


Table 1-1. Load estimates and regression model input data.-Continued

[[Numbers are unrounded model inputs. Numbers in red are from Joseph Salata, U.S. Environmental Protection Agency, written commun., 2012. USGS, U.S. Geological Survey; ID, identification; $1 \mathrm{~b} / \mathrm{d}$, pounds per day; $\mathrm{lb} / \mathrm{yr}$, pounds per year; $\mathrm{lb} / \mathrm{mi}^{2} /$ year, pounds per square mile per year; $\mathrm{mi}^{2}$, square mile; S., south; N., north]

\begin{tabular}{|c|c|c|c|c|c|c|c|c|c|}
\hline $\begin{array}{c}\text { USGS } \\
\text { station ID } \\
\text { or name of } \\
\text { unmonitored } \\
\text { area } \\
\text { (figs. 1-2, } \\
\text { tables 1, 2) }\end{array}$ & $\begin{array}{c}\text { Water } \\
\text { year }\end{array}$ & $\begin{array}{c}\text { Drainage } \\
\text { area } \\
\left(\mathrm{mi}^{2}\right)\end{array}$ & $\begin{array}{l}\text { Long } \\
\text { Island } \\
\text { Sound } \\
\text { manage- } \\
\text { ment } \\
\text { zone } \\
\text { (fig. 12) }\end{array}$ & $\begin{array}{c}\text { Percentage } \\
\text { of } \\
\text { developed } \\
\text { land }\end{array}$ & $\begin{array}{c}\text { Percentage } \\
\text { of } \\
\text { cultivated } \\
\text { crops }\end{array}$ & $\begin{array}{c}\text { Total } \\
\text { nitrogen } \\
\text { load } \\
\text { from } \\
\text { wastewater- } \\
\text { treatment } \\
\text { facilities in } \\
\text { Connecticut, } \\
\text { in lb/yr }\end{array}$ & $\begin{array}{c}\text { Total } \\
\text { nitrogen yield } \\
\text { from } \\
\text { wastewater- } \\
\text { treatment } \\
\text { facilities in } \\
\text { Connecticut, } \\
\text { in } \mathrm{lb} / \mathrm{mi}^{2} / \mathrm{yr}\end{array}$ & $\begin{array}{c}\text { Total nitrogen } \\
\text { yield } \\
\text { from } \\
\text { wastewater- } \\
\text { treatment } \\
\text { facilities } \\
\text { outside } \\
\text { Connecticut, } \\
\text { in lb/mi } / \mathrm{yr}\end{array}$ & $\begin{array}{c}\text { Annual } \\
\text { mean } \\
\text { runoff, } \\
\text { in inches }\end{array}$ \\
\hline \multicolumn{10}{|c|}{ B. Input data below for unmonitored sites/basins where predictions are necessary-Continued } \\
\hline 01127500 & 1999 & 89.3 & 1 & 7.8 & 2.5 & 0 & 0 & 0 & 22.7 \\
\hline 01127500 & 2000 & 89.3 & 1 & 7.8 & 2.5 & 0 & 0 & 0 & 22.9 \\
\hline 01127500 & 2001 & 89.3 & 1 & 7.8 & 2.5 & 0 & 0 & 0 & 24.3 \\
\hline 01127500 & 2002 & 89.3 & 1 & 7.8 & 2.5 & 0 & 0 & 0 & 11.0 \\
\hline 01127500 & 2003 & 89.3 & 1 & 7.8 & 2.5 & 0 & 0 & 0 & 31.2 \\
\hline 01127500 & 2004 & 89.3 & 1 & 7.8 & 2.5 & 0 & 0 & 0 & 27.0 \\
\hline 01127500 & 2005 & 89.3 & 1 & 7.8 & 2.5 & 0 & 0 & 0 & 27.9 \\
\hline 01127500 & 2006 & 89.3 & 1 & 7.8 & 2.5 & 0 & 0 & 0 & 33.7 \\
\hline 01127500 & 2007 & 89.3 & 1 & 7.8 & 2.5 & 0 & 0 & 0 & 31.3 \\
\hline 011230695 & 1999 & 512.0 & 1 & 9.5 & 0.8 & 252,345 & 493 & 0 & 22.7 \\
\hline 011230695 & 2000 & 512.0 & 1 & 9.5 & 0.8 & 232,410 & 454 & 0 & 22.9 \\
\hline 011230695 & 2001 & 512.0 & 1 & 9.5 & 0.8 & 150,745 & 294 & 0 & 24.3 \\
\hline 011230695 & 2002 & 512.0 & 1 & 9.5 & 0.8 & 180,645 & 353 & 0 & 11.0 \\
\hline 011230695 & 2003 & 512.0 & 1 & 9.5 & 0.8 & 177,581 & 347 & 0 & 31.2 \\
\hline 011230695 & 2004 & 512.0 & 1 & 9.5 & 0.8 & 170,820 & 334 & 0 & 27.0 \\
\hline 011230695 & 2005 & 512.0 & 1 & 9.5 & 0.8 & 145,169 & 284 & 0 & 27.9 \\
\hline 011230695 & 2006 & 512.0 & 1 & 9.5 & 0.8 & 130,153 & 254 & 0 & 33.7 \\
\hline 011230695 & 2007 & 512.0 & 1 & 9.5 & 0.8 & 150,390 & 294 & 0 & 31.3 \\
\hline 01195100 & 1999 & 5.7 & 3 & 11.5 & 0.2 & 0 & 0 & 0 & 15.8 \\
\hline 01195100 & 2000 & 5.7 & 3 & 11.5 & 0.2 & 0 & 0 & 0 & 21.6 \\
\hline 01195100 & 2001 & 5.7 & 3 & 11.5 & 0.2 & 0 & 0 & 0 & 24.7 \\
\hline 01195100 & 2002 & 5.7 & 3 & 11.5 & 0.2 & 0 & 0 & 0 & 11.1 \\
\hline 01195100 & 2003 & 5.7 & 3 & 11.5 & 0.2 & 0 & 0 & 0 & 28.5 \\
\hline 01195100 & 2004 & 5.7 & 3 & 11.5 & 0.2 & 0 & 0 & 0 & 23.2 \\
\hline 01195100 & 2005 & 5.7 & 3 & 11.5 & 0.2 & 0 & 0 & 0 & 22.2 \\
\hline 01195100 & 2006 & 5.7 & 3 & 11.5 & 0.2 & 0 & 0 & 0 & 30.9 \\
\hline 01195100 & 2007 & 5.7 & 3 & 11.5 & 0.2 & 0 & 0 & 0 & 28.7 \\
\hline 01208873 & 1999 & 10.6 & 5 & 92.6 & 0.0 & 0 & 0 & 0 & 13.9 \\
\hline 01208873 & 2000 & 10.6 & 5 & 92.6 & 0.0 & 0 & 0 & 0 & 21.3 \\
\hline 01208873 & 2001 & 10.6 & 5 & 92.6 & 0.0 & 0 & 0 & 0 & 20.4 \\
\hline 01208873 & 2002 & 10.6 & 5 & 92.6 & 0.0 & 0 & 0 & 0 & 12.5 \\
\hline 01208873 & 2003 & 10.6 & 5 & 92.6 & 0.0 & 0 & 0 & 0 & 24.0 \\
\hline 01208873 & 2004 & 10.6 & 5 & 92.6 & 0.0 & 0 & 0 & 0 & 21.9 \\
\hline 01208873 & 2005 & 10.6 & 5 & 92.6 & 0.0 & 0 & 0 & 0 & 17.3 \\
\hline
\end{tabular}


Table 1-1. Load estimates and regression model input data.-Continued

[[Numbers are unrounded model inputs. Numbers in red are from Joseph Salata, U.S. Environmental Protection Agency, written commun., 2012. USGS, U.S. Geological Survey; ID, identification; lb/d, pounds per day; lb/yr, pounds per year; $1 \mathrm{~b} / \mathrm{mi}^{2} /$ year, pounds per square mile per year; $\mathrm{mi}^{2}$, square mile; S., south; N., north]

\begin{tabular}{|c|c|c|c|c|c|c|c|c|c|}
\hline $\begin{array}{c}\text { USGS } \\
\text { station ID } \\
\text { or name of } \\
\text { unmonitored } \\
\text { area } \\
\text { (figs. 1-2, } \\
\text { tables 1, 2) }\end{array}$ & $\begin{array}{c}\text { Water } \\
\text { year }\end{array}$ & $\begin{array}{c}\text { Drainage } \\
\text { area } \\
\left(\mathrm{mi}^{2}\right)\end{array}$ & $\begin{array}{l}\text { Long } \\
\text { Island } \\
\text { Sound } \\
\text { manage- } \\
\text { ment } \\
\text { zone } \\
\text { (fig. 12) }\end{array}$ & $\begin{array}{c}\text { Percentage } \\
\text { of } \\
\text { developed } \\
\text { land }\end{array}$ & $\begin{array}{c}\text { Percentage } \\
\text { of } \\
\text { cultivated } \\
\text { crops }\end{array}$ & $\begin{array}{c}\text { Total } \\
\text { nitrogen } \\
\text { load } \\
\text { from } \\
\text { wastewater- } \\
\text { treatment } \\
\text { facilities in } \\
\text { Connecticut, } \\
\text { in lb/yr }\end{array}$ & $\begin{array}{c}\text { Total } \\
\text { nitrogen yield } \\
\text { from } \\
\text { wastewater- } \\
\text { treatment } \\
\text { facilities in } \\
\text { Connecticut, } \\
\text { in } \mathrm{lb} / \mathrm{mi}^{2} / \mathrm{yr}\end{array}$ & $\begin{array}{c}\text { Total nitrogen } \\
\text { yield } \\
\text { from } \\
\text { wastewater- } \\
\text { treatment } \\
\text { facilities } \\
\text { outside } \\
\text { Connecticut, } \\
\text { in lb/mi²/yr }\end{array}$ & $\begin{array}{c}\text { Annual } \\
\text { mean } \\
\text { runoff, } \\
\text { in inches }\end{array}$ \\
\hline \multicolumn{10}{|c|}{ B. Input data below for unmonitored sites/basins where predictions are necessary-Continued } \\
\hline 01208873 & 2006 & 10.6 & 5 & 92.6 & 0.0 & 0 & 0 & 0 & 32.1 \\
\hline 01208873 & 2007 & 10.6 & 5 & 92.6 & 0.0 & 0 & 0 & 0 & 25.1 \\
\hline 01208950 & 1999 & 7.4 & 5 & 37.8 & 0.0 & 0 & 0 & 0 & 15.3 \\
\hline 01208950 & 2000 & 7.4 & 5 & 37.8 & 0.0 & 0 & 0 & 0 & 24.8 \\
\hline 01208950 & 2001 & 7.4 & 5 & 37.8 & 0.0 & 0 & 0 & 0 & 23.3 \\
\hline 01208950 & 2002 & 7.4 & 5 & 37.8 & 0.0 & 0 & 0 & 0 & 12.6 \\
\hline 01208950 & 2003 & 7.4 & 5 & 37.8 & 0.0 & 0 & 0 & 0 & 32.3 \\
\hline 01208950 & 2004 & 7.4 & 5 & 37.8 & 0.0 & 0 & 0 & 0 & 30.0 \\
\hline 01208950 & 2005 & 7.4 & 5 & 37.8 & 0.0 & 0 & 0 & 0 & 21.3 \\
\hline 01208950 & 2006 & 7.4 & 5 & 37.8 & 0.0 & 0 & 0 & 0 & 41.1 \\
\hline 01208950 & 2007 & 7.4 & 5 & 37.8 & 0.0 & 0 & 0 & 0 & 33.2 \\
\hline $\mathrm{CT}$ mainstem $\mathrm{S}$. & 1999 & 227.5 & 2 & 15.3 & 0.5 & $1,211,427$ & 5,326 & 0 & 22.5 \\
\hline CT mainstem S. & 2000 & 227.5 & 2 & 15.3 & 0.5 & $1,021,506$ & 4,491 & 0 & 24.3 \\
\hline CT mainstem S. & 2001 & 227.5 & 2 & 15.3 & 0.5 & $1,049,740$ & 4,615 & 0 & 21.2 \\
\hline CT mainstem S. & 2002 & 227.5 & 2 & 15.3 & 0.5 & 955,953 & 4,202 & 0 & 11.1 \\
\hline CT mainstem S. & 2003 & 227.5 & 2 & 15.3 & 0.5 & 876,494 & 3,853 & 0 & 28.4 \\
\hline CT mainstem S. & 2004 & 227.5 & 2 & 15.3 & 0.5 & 720,465 & 3,167 & 0 & 30.0 \\
\hline CT mainstem S. & 2005 & 227.5 & 2 & 15.3 & 0.5 & 728,197 & 3,201 & 0 & 27.8 \\
\hline $\mathrm{CT}$ mainstem $\mathrm{S}$. & 2006 & 227.5 & 2 & 15.3 & 0.5 & 700,973 & 3,082 & 0 & 42.7 \\
\hline CT mainstem S. & 2007 & 227.5 & 2 & 15.3 & 0.5 & 601,859 & 2,646 & 0 & 30.9 \\
\hline CT mainstem S. & 2008 & 227.5 & 2 & 15.3 & 0.5 & 590,925 & 2,598 & 0 & 26.5 \\
\hline CT mainstem S. & 2009 & 227.5 & 2 & 15.3 & 0.5 & 650,609 & 2,860 & 0 & 31.0 \\
\hline CT mainstem N. & 1999 & 139.5 & 2 & 49.8 & 3.8 & $3,529,473$ & 25,308 & 0 & 18.3 \\
\hline $\mathrm{CT}$ mainstem $\mathrm{N}$. & 2000 & 139.5 & 2 & 49.8 & 3.8 & $3,589,728$ & 25,740 & 0 & 24.3 \\
\hline CT mainstem N. & 2001 & 139.5 & 2 & 49.8 & 3.8 & $2,956,135$ & 21,197 & 0 & 20.4 \\
\hline CT mainstem N. & 2002 & 139.5 & 2 & 49.8 & 3.8 & $3,277,862$ & 23,503 & 0 & 11.6 \\
\hline CT mainstem N. & 2003 & 139.5 & 2 & 49.8 & 3.8 & $3,271,542$ & 23,458 & 0 & 23.7 \\
\hline CT mainstem N. & 2004 & 139.5 & 2 & 49.8 & 3.8 & $3,294,500$ & 23,623 & 0 & 26.0 \\
\hline CT mainstem $\mathrm{N}$. & 2005 & 139.5 & 2 & 49.8 & 3.8 & $3,548,473$ & 25,444 & 0 & 24.1 \\
\hline CT mainstem N. & 2006 & 139.5 & 2 & 49.8 & 3.8 & $3,761,075$ & 26,968 & 0 & 37.8 \\
\hline CT mainstem N. & 2007 & 139.5 & 2 & 49.8 & 3.8 & $2,966,652$ & 21,272 & 0 & 21.9 \\
\hline CT mainstem N. & 2008 & 139.5 & 2 & 49.8 & 3.8 & $2,782,560$ & 19,952 & 0 & 24.2 \\
\hline CT mainstem N. & 2009 & 139.5 & 2 & 49.8 & 3.8 & $2,366,128$ & 16,966 & 0 & 27.9 \\
\hline Eightmile & 1999 & 62.4 & 2 & 6.2 & 0.5 & 0 & 0 & 0 & 22.5 \\
\hline
\end{tabular}


Table 1-1. Load estimates and regression model input data.-Continued

[[Numbers are unrounded model inputs. Numbers in red are from Joseph Salata, U.S. Environmental Protection Agency, written commun., 2012. USGS, U.S. Geological Survey; ID, identification; $1 \mathrm{~b} / \mathrm{d}$, pounds per day; $\mathrm{lb} / \mathrm{yr}$, pounds per year; $\mathrm{lb} / \mathrm{mi}^{2} /$ year, pounds per square mile per year; $\mathrm{mi}^{2}$, square mile; S., south; N., north]

\begin{tabular}{|c|c|c|c|c|c|c|c|c|c|}
\hline $\begin{array}{c}\text { USGS } \\
\text { station ID } \\
\text { or name of } \\
\text { unmonitored } \\
\text { area } \\
\text { (figs. 1-2, } \\
\text { tables 1, 2) }\end{array}$ & $\begin{array}{c}\text { Water } \\
\text { year }\end{array}$ & $\begin{array}{c}\text { Drainage } \\
\text { area } \\
\left(\mathrm{mi}^{2}\right)\end{array}$ & $\begin{array}{l}\text { Long } \\
\text { Island } \\
\text { Sound } \\
\text { manage- } \\
\text { ment } \\
\text { zone } \\
\text { (fig. 12) }\end{array}$ & $\begin{array}{c}\text { Percentage } \\
\text { of } \\
\text { developed } \\
\text { land }\end{array}$ & $\begin{array}{c}\text { Percentage } \\
\text { of } \\
\text { cultivated } \\
\text { crops }\end{array}$ & $\begin{array}{c}\text { Total } \\
\text { nitrogen } \\
\text { load } \\
\text { from } \\
\text { wastewater- } \\
\text { treatment } \\
\text { facilities in } \\
\text { Connecticut, } \\
\text { in lb/yr }\end{array}$ & $\begin{array}{c}\text { Total } \\
\text { nitrogen yield } \\
\text { from } \\
\text { wastewater- } \\
\text { treatment } \\
\text { facilities in } \\
\text { Connecticut, } \\
\text { in } \mathrm{lb} / \mathrm{mi}^{2} / \mathrm{yr}\end{array}$ & $\begin{array}{c}\text { Total nitrogen } \\
\text { yield } \\
\text { from } \\
\text { wastewater- } \\
\text { treatment } \\
\text { facilities } \\
\text { outside } \\
\text { Connecticut, } \\
\text { in lb/mi²/yr }\end{array}$ & $\begin{array}{c}\text { Annual } \\
\text { mean } \\
\text { runoff, } \\
\text { in inches }\end{array}$ \\
\hline \multicolumn{10}{|c|}{ B. Input data below for unmonitored sites/basins where predictions are necessary-Continued } \\
\hline Eightmile & 2000 & 62.4 & 2 & 6.2 & 0.5 & 0 & 0 & 0 & 24.3 \\
\hline Eightmile & 2001 & 62.4 & 2 & 6.2 & 0.5 & 0 & 0 & 0 & 21.2 \\
\hline Eightmile & 2002 & 62.4 & 2 & 6.2 & 0.5 & 0 & 0 & 0 & 11.1 \\
\hline Eightmile & 2003 & 62.4 & 2 & 6.2 & 0.5 & 0 & 0 & 0 & 28.4 \\
\hline Eightmile & 2004 & 62.4 & 2 & 6.2 & 0.5 & 0 & 0 & 0 & 30.0 \\
\hline Eightmile & 2005 & 62.4 & 2 & 6.2 & 0.5 & 0 & 0 & 0 & 27.8 \\
\hline Eightmile & 2006 & 62.4 & 2 & 6.2 & 0.5 & 0 & 0 & 0 & 42.7 \\
\hline Eightmile & 2007 & 62.4 & 2 & 6.2 & 0.5 & 0 & 0 & 0 & 30.9 \\
\hline Eightmile & 2008 & 62.4 & 2 & 6.2 & 0.5 & 0 & 0 & 0 & 26.5 \\
\hline Eightmile & 2009 & 62.4 & 2 & 6.2 & 0.5 & 0 & 0 & 0 & 31.0 \\
\hline Farmington & 1999 & 30.6 & 2 & 38.8 & 7.5 & 163,629 & 5,339 & 0 & 19.8 \\
\hline Farmington & 2000 & 30.6 & 2 & 38.8 & 7.5 & 171,288 & 5,589 & 0 & 29.7 \\
\hline Farmington & 2001 & 30.6 & 2 & 38.8 & 7.5 & 112,785 & 3,680 & 0 & 28.1 \\
\hline Farmington & 2002 & 30.6 & 2 & 38.8 & 7.5 & 155,898 & 5,087 & 0 & 8.9 \\
\hline Farmington & 2003 & 30.6 & 2 & 38.8 & 7.5 & 154,649 & 5,046 & 0 & 32.0 \\
\hline Farmington & 2004 & 30.6 & 2 & 38.8 & 7.5 & 161,876 & 5,282 & 0 & 27.0 \\
\hline Farmington & 2005 & 30.6 & 2 & 38.8 & 7.5 & 167,140 & 5,454 & 0 & 23.3 \\
\hline Farmington & 2006 & 30.6 & 2 & 38.8 & 7.5 & 163,202 & 5,325 & 0 & 39.6 \\
\hline Farmington & 2007 & 30.6 & 2 & 38.8 & 7.5 & 155,282 & 5,067 & 0 & 26.2 \\
\hline Farmington & 2008 & 30.6 & 2 & 38.8 & 7.5 & 161,083 & 5,256 & 0 & 35.3 \\
\hline Farmington & 2009 & 30.6 & 2 & 38.8 & 7.5 & 163,483 & 5,335 & 0 & 31.0 \\
\hline Hockanum & 1999 & 3.5 & 2 & 71.2 & 0.2 & 0 & 0 & 0 & 20.2 \\
\hline Hockanum & 2000 & 3.5 & 2 & 71.2 & 0.2 & 0 & 0 & 0 & 24.0 \\
\hline Hockanum & 2001 & 3.5 & 2 & 71.2 & 0.2 & 0 & 0 & 0 & 18.5 \\
\hline Hockanum & 2002 & 3.5 & 2 & 71.2 & 0.2 & 0 & 0 & 0 & 11.9 \\
\hline Hockanum & 2003 & 3.5 & 2 & 71.2 & 0.2 & 0 & 0 & 0 & 26.8 \\
\hline Hockanum & 2004 & 3.5 & 2 & 71.2 & 0.2 & 0 & 0 & 0 & 26.5 \\
\hline Hockanum & 2005 & 3.5 & 2 & 71.2 & 0.2 & 0 & 0 & 0 & 25.9 \\
\hline Hockanum & 2006 & 3.5 & 2 & 71.2 & 0.2 & 0 & 0 & 0 & 39.8 \\
\hline Hockanum & 2007 & 3.5 & 2 & 71.2 & 0.2 & 0 & 0 & 0 & 24.7 \\
\hline Hockanum & 2008 & 3.5 & 2 & 71.2 & 0.2 & 0 & 0 & 0 & 23.8 \\
\hline Hockanum & 2009 & 3.5 & 2 & 71.2 & 0.2 & 0 & 0 & 0 & 28.9 \\
\hline Housatonic & 1999 & 94.3 & 4 & 43.0 & 0.3 & 642,036 & 6,812 & 0 & 21.7 \\
\hline Housatonic & 2000 & 94.3 & 4 & 43.0 & 0.3 & 659,532 & 6,998 & 0 & 24.7 \\
\hline Housatonic & 2001 & 94.3 & 4 & 43.0 & 0.3 & 595,315 & 6,316 & 0 & 20.9 \\
\hline
\end{tabular}


Table 1-1. Load estimates and regression model input data.-Continued

[[Numbers are unrounded model inputs. Numbers in red are from Joseph Salata, U.S. Environmental Protection Agency, written commun., 2012. USGS, U.S. Geological Survey; ID, identification; lb/d, pounds per day; lb/yr, pounds per year; $1 \mathrm{~b} / \mathrm{mi}^{2} /$ year, pounds per square mile per year; $\mathrm{mi}^{2}$, square mile; S., south; N., north]

\begin{tabular}{|c|c|c|c|c|c|c|c|c|c|}
\hline $\begin{array}{c}\text { USGS } \\
\text { station ID } \\
\text { or name of } \\
\text { unmonitored } \\
\text { area } \\
\text { (figs. 1-2, } \\
\text { tables 1, 2) }\end{array}$ & $\begin{array}{c}\text { Water } \\
\text { year }\end{array}$ & $\begin{array}{c}\text { Drainage } \\
\text { area } \\
\left(\mathrm{mi}^{2}\right)\end{array}$ & $\begin{array}{l}\text { Long } \\
\text { Island } \\
\text { Sound } \\
\text { manage- } \\
\text { ment } \\
\text { zone } \\
\text { (fig. 12) }\end{array}$ & $\begin{array}{c}\text { Percentage } \\
\text { of } \\
\text { developed } \\
\text { land }\end{array}$ & $\begin{array}{l}\text { Percentage } \\
\text { of } \\
\text { cultivated } \\
\text { crops }\end{array}$ & $\begin{array}{c}\text { Total } \\
\text { nitrogen } \\
\text { load } \\
\text { from } \\
\text { wastewater- } \\
\text { treatment } \\
\text { facilities in } \\
\text { Connecticut, } \\
\text { in lb/yr }\end{array}$ & $\begin{array}{c}\text { Total } \\
\text { nitrogen yield } \\
\text { from } \\
\text { wastewater- } \\
\text { treatment } \\
\text { facilities in } \\
\text { Connecticut, } \\
\text { in } \mathrm{lb} / \mathrm{mi}^{2} / \mathrm{yr}\end{array}$ & $\begin{array}{c}\text { Total nitrogen } \\
\text { yield } \\
\text { from } \\
\text { wastewater- } \\
\text { treatment } \\
\text { facilities } \\
\text { outside } \\
\text { Connecticut, } \\
\text { in lb/mi²/yr }\end{array}$ & $\begin{array}{c}\text { Annual } \\
\text { mean } \\
\text { runoff, } \\
\text { in inches }\end{array}$ \\
\hline \multicolumn{10}{|c|}{ B. Input data below for unmonitored sites/basins where predictions are necessary-Continued } \\
\hline Housatonic & 2002 & 94.3 & 4 & 43.0 & 0.3 & 588,035 & 6,239 & 0 & 11.5 \\
\hline Housatonic & 2003 & 94.3 & 4 & 43.0 & 0.3 & 707,013 & 7,501 & 0 & 26.7 \\
\hline Housatonic & 2004 & 94.3 & 4 & 43.0 & 0.3 & 576,344 & 6,115 & 0 & 27.6 \\
\hline Housatonic & 2005 & 94.3 & 4 & 43.0 & 0.3 & 582,092 & 6,176 & 0 & 21.1 \\
\hline Housatonic & 2006 & 94.3 & 4 & 43.0 & 0.3 & 667,356 & 7,081 & 0 & 35.6 \\
\hline Housatonic & 2007 & 94.3 & 4 & 43.0 & 0.3 & 691,890 & 7,341 & 0 & 26.1 \\
\hline Housatonic & 2008 & 94.3 & 4 & 43.0 & 0.3 & 884,494 & 9,385 & 0 & 27.7 \\
\hline Housatonic & 2009 & 94.3 & 4 & 43.0 & 0.3 & 601,585 & 6,383 & 0 & 29.3 \\
\hline Mattabesett & 1999 & 108.9 & 2 & 34.3 & 1.0 & 0 & 0 & 0 & 19.7 \\
\hline Mattabesett & 2000 & 108.9 & 2 & 34.3 & 1.0 & 0 & 0 & 0 & 25.6 \\
\hline Mattabesett & 2001 & 108.9 & 2 & 34.3 & 1.0 & 0 & 0 & 0 & 24.6 \\
\hline Mattabesett & 2002 & 108.9 & 2 & 34.3 & 1.0 & 0 & 0 & 0 & 13.6 \\
\hline Mattabesett & 2003 & 108.9 & 2 & 34.3 & 1.0 & 0 & 0 & 0 & 35.0 \\
\hline Mattabesett & 2004 & 108.9 & 2 & 34.3 & 1.0 & 0 & 0 & 0 & 31.2 \\
\hline Mattabesett & 2005 & 108.9 & 2 & 34.3 & 1.0 & 0 & 0 & 0 & 29.2 \\
\hline Mattabesett & 2006 & 108.9 & 2 & 34.3 & 1.0 & 0 & 0 & 0 & 45.9 \\
\hline Mattabesett & 2007 & 108.9 & 2 & 34.3 & 1.0 & 0 & 0 & 0 & 34.8 \\
\hline Mattabesett & 2008 & 108.9 & 2 & 34.3 & 1.0 & 0 & 0 & 0 & 28.8 \\
\hline Mattabesett & 2009 & 108.9 & 2 & 34.3 & 1.0 & 0 & 0 & 0 & 33.5 \\
\hline Scantic & 1999 & 98.1 & 2 & 17.5 & 7.0 & 0 & 0 & 0 & 18.3 \\
\hline Scantic & 2000 & 98.1 & 2 & 17.5 & 7.0 & 0 & 0 & 0 & 24.3 \\
\hline Scantic & 2001 & 98.1 & 2 & 17.5 & 7.0 & 0 & 0 & 0 & 20.4 \\
\hline Scantic & 2002 & 98.1 & 2 & 17.5 & 7.0 & 0 & 0 & 0 & 11.6 \\
\hline Scantic & 2003 & 98.1 & 2 & 17.5 & 7.0 & 0 & 0 & 0 & 23.7 \\
\hline Scantic & 2004 & 98.1 & 2 & 17.5 & 7.0 & 0 & 0 & 0 & 26.0 \\
\hline Scantic & 2005 & 98.1 & 2 & 17.5 & 7.0 & 0 & 0 & 0 & 24.1 \\
\hline Scantic & 2006 & 98.1 & 2 & 17.5 & 7.0 & 0 & 0 & 0 & 37.8 \\
\hline Scantic & 2007 & 98.1 & 2 & 17.5 & 7.0 & 0 & 0 & 0 & 21.9 \\
\hline Scantic & 2008 & 98.1 & 2 & 17.5 & 7.0 & 0 & 0 & 0 & 24.2 \\
\hline Scantic & 2009 & 98.1 & 2 & 17.5 & 7.0 & 0 & 0 & 0 & 27.9 \\
\hline Stony Brook & 1999 & 44.6 & 2 & 19.1 & 7.1 & 52,190 & 1,171 & 0 & 19.8 \\
\hline Stony Brook & 2000 & 44.6 & 2 & 19.1 & 7.1 & 49,776 & 1,117 & 0 & 29.7 \\
\hline Stony Brook & 2001 & 44.6 & 2 & 19.1 & 7.1 & 59,130 & 1,327 & 0 & 28.1 \\
\hline Stony Brook & 2002 & 44.6 & 2 & 19.1 & 7.1 & 12,282 & 276 & 0 & 8.9 \\
\hline Stony Brook & 2003 & 44.6 & 2 & 19.1 & 7.1 & 12,743 & 286 & 0 & 32.0 \\
\hline
\end{tabular}


Table 1-1. Load estimates and regression model input data.-Continued

[[Numbers are unrounded model inputs. Numbers in red are from Joseph Salata, U.S. Environmental Protection Agency, written commun., 2012. USGS, U.S. Geological Survey; ID, identification; $1 \mathrm{~b} / \mathrm{d}$, pounds per day; $\mathrm{lb} / \mathrm{yr}$, pounds per year; $\mathrm{lb} / \mathrm{mi}^{2} /$ year, pounds per square mile per year; $\mathrm{mi}^{2}$, square mile; S., south; N., north]

\begin{tabular}{|c|c|c|c|c|c|c|c|c|c|}
\hline $\begin{array}{c}\text { USGS } \\
\text { station ID } \\
\text { or name of } \\
\text { unmonitored } \\
\text { area } \\
\text { (figs. 1-2, } \\
\text { tables 1, 2) }\end{array}$ & $\begin{array}{c}\text { Water } \\
\text { year }\end{array}$ & $\begin{array}{c}\text { Drainage } \\
\text { area } \\
\left(\mathrm{mi}^{2}\right)\end{array}$ & $\begin{array}{l}\text { Long } \\
\text { Island } \\
\text { Sound } \\
\text { manage- } \\
\text { ment } \\
\text { zone } \\
\text { (fig. 12) }\end{array}$ & $\begin{array}{c}\text { Percentage } \\
\text { of } \\
\text { developed } \\
\text { land }\end{array}$ & $\begin{array}{l}\text { Percentage } \\
\text { of } \\
\text { cultivated } \\
\text { crops }\end{array}$ & $\begin{array}{c}\text { Total } \\
\text { nitrogen } \\
\text { load } \\
\text { from } \\
\text { wastewater- } \\
\text { treatment } \\
\text { facilities in } \\
\text { Connecticut, } \\
\text { in lb/yr }\end{array}$ & $\begin{array}{c}\text { Total } \\
\text { nitrogen yield } \\
\text { from } \\
\text { wastewater- } \\
\text { treatment } \\
\text { facilities in } \\
\text { Connecticut, } \\
\text { in } \mathrm{lb} / \mathrm{mi}^{2} / \mathrm{yr}\end{array}$ & $\begin{array}{c}\text { Total nitrogen } \\
\text { yield } \\
\text { from } \\
\text { wastewater- } \\
\text { treatment } \\
\text { facilities } \\
\text { outside } \\
\text { Connecticut, } \\
\text { in } \mathrm{lb} / \mathrm{mi}^{2} / \mathrm{yr} \\
\end{array}$ & $\begin{array}{c}\text { Annual } \\
\text { mean } \\
\text { runoff, } \\
\text { in inches }\end{array}$ \\
\hline \multicolumn{10}{|c|}{ B. Input data below for unmonitored sites/basins where predictions are necessary-Continued } \\
\hline Stony Brook & 2004 & 44.6 & 2 & 19.1 & 7.1 & 11,958 & 268 & 0 & 27.0 \\
\hline Stony Brook & 2005 & 44.6 & 2 & 19.1 & 7.1 & 21,490 & 482 & 0 & 23.3 \\
\hline Stony Brook & 2006 & 44.6 & 2 & 19.1 & 7.1 & 37,026 & 831 & 0 & 39.6 \\
\hline Stony Brook & 2007 & 44.6 & 2 & 19.1 & 7.1 & 24,023 & 539 & 0 & 26.2 \\
\hline Stony Brook & 2008 & 44.6 & 2 & 19.1 & 7.1 & 29,329 & 658 & 0 & 35.3 \\
\hline Stony Brook & 2009 & 44.6 & 2 & 19.1 & 7.1 & 26,210 & 588 & 0 & 31.0 \\
\hline Park & 1999 & 77.2 & 2 & 64.5 & 0.9 & 0 & 0 & 0 & 19.8 \\
\hline Park & 2000 & 77.2 & 2 & 64.5 & 0.9 & 0 & 0 & 0 & 29.7 \\
\hline Park & 2001 & 77.2 & 2 & 64.5 & 0.9 & 0 & 0 & 0 & 28.1 \\
\hline Park & 2002 & 77.2 & 2 & 64.5 & 0.9 & 0 & 0 & 0 & 8.9 \\
\hline Park & 2003 & 77.2 & 2 & 64.5 & 0.9 & 0 & 0 & 0 & 32.0 \\
\hline Park & 2004 & 77.2 & 2 & 64.5 & 0.9 & 0 & 0 & 0 & 27.0 \\
\hline Park & 2005 & 77.2 & 2 & 64.5 & 0.9 & 0 & 0 & 0 & 23.3 \\
\hline Park & 2006 & 77.2 & 2 & 64.5 & 0.9 & 0 & 0 & 0 & 39.6 \\
\hline Park & 2007 & 77.2 & 2 & 64.5 & 0.9 & 0 & 0 & 0 & 26.2 \\
\hline Park & 2008 & 77.2 & 2 & 64.5 & 0.9 & 0 & 0 & 0 & 35.3 \\
\hline Park & 2009 & 77.2 & 2 & 64.5 & 0.9 & 0 & 0 & 0 & 31.0 \\
\hline Salmon & 1999 & 48.4 & 2 & 10.4 & 0.2 & 0 & 0 & 0 & 22.5 \\
\hline Salmon & 2000 & 48.4 & 2 & 10.4 & 0.2 & 0 & 0 & 0 & 24.3 \\
\hline Salmon & 2001 & 48.4 & 2 & 10.4 & 0.2 & 0 & 0 & 0 & 21.2 \\
\hline Salmon & 2002 & 48.4 & 2 & 10.4 & 0.2 & 0 & 0 & 0 & 11.1 \\
\hline Salmon & 2003 & 48.4 & 2 & 10.4 & 0.2 & 0 & 0 & 0 & 28.4 \\
\hline Salmon & 2004 & 48.4 & 2 & 10.4 & 0.2 & 0 & 0 & 0 & 30.0 \\
\hline Salmon & 2005 & 48.4 & 2 & 10.4 & 0.2 & 0 & 0 & 0 & 27.8 \\
\hline Salmon & 2006 & 48.4 & 2 & 10.4 & 0.2 & 0 & 0 & 0 & 42.7 \\
\hline Salmon & 2007 & 48.4 & 2 & 10.4 & 0.2 & 0 & 0 & 0 & 30.9 \\
\hline Salmon & 2008 & 48.4 & 2 & 10.4 & 0.2 & 0 & 0 & 0 & 26.5 \\
\hline Salmon & 2009 & 48.4 & 2 & 10.4 & 0.2 & 0 & 0 & 0 & 31.0 \\
\hline Yantic & 1999 & 8.6 & 1 & 43.2 & 0.3 & 304,947 & 35,394 & 0 & 22.7 \\
\hline Yantic & 2000 & 8.6 & 1 & 43.2 & 0.3 & 270,474 & 31,393 & 0 & 22.9 \\
\hline Yantic & 2001 & 8.6 & 1 & 43.2 & 0.3 & 267,910 & 31,095 & 0 & 24.3 \\
\hline Yantic & 2002 & 8.6 & 1 & 43.2 & 0.3 & 276,042 & 32,039 & 0 & 11.0 \\
\hline Yantic & 2003 & 8.6 & 1 & 43.2 & 0.3 & 317,709 & 36,875 & 0 & 31.2 \\
\hline Yantic & 2004 & 8.6 & 1 & 43.2 & 0.3 & 318,827 & 37,005 & 0 & 27.0 \\
\hline Yantic & 2005 & 8.6 & 1 & 43.2 & 0.3 & 276,573 & 32,101 & 0 & 27.9 \\
\hline
\end{tabular}


Table 1-1. Load estimates and regression model input data.-Continued

[[Numbers are unrounded model inputs. Numbers in red are from Joseph Salata, U.S. Environmental Protection Agency, written commun., 2012. USGS, U.S. Geological Survey; ID, identification; lb/d, pounds per day; lb/yr, pounds per year; $1 \mathrm{~b} / \mathrm{mi}^{2} /$ year, pounds per square mile per year; $\mathrm{mi}^{2}$, square mile; S., south; N., north]

\begin{tabular}{|c|c|c|c|c|c|c|c|c|c|}
\hline $\begin{array}{c}\text { USGS } \\
\text { station ID } \\
\text { or name of } \\
\text { unmonitored } \\
\text { area } \\
\text { (figs. 1-2, } \\
\text { tables 1, 2) }\end{array}$ & $\begin{array}{c}\text { Water } \\
\text { year }\end{array}$ & $\begin{array}{c}\text { Drainage } \\
\text { area } \\
\left(\mathrm{mi}^{2}\right)\end{array}$ & $\begin{array}{l}\text { Long } \\
\text { Island } \\
\text { Sound } \\
\text { manage- } \\
\text { ment } \\
\text { zone } \\
\text { (fig. 12) }\end{array}$ & $\begin{array}{c}\text { Percentage } \\
\text { of } \\
\text { developed } \\
\text { land }\end{array}$ & $\begin{array}{l}\text { Percentage } \\
\text { of } \\
\text { cultivated } \\
\text { crops }\end{array}$ & $\begin{array}{c}\text { Total } \\
\text { nitrogen } \\
\text { load } \\
\text { from } \\
\text { wastewater- } \\
\text { treatment } \\
\text { facilities in } \\
\text { Connecticut, } \\
\text { in lb/yr }\end{array}$ & $\begin{array}{c}\text { Total } \\
\text { nitrogen yield } \\
\text { from } \\
\text { wastewater- } \\
\text { treatment } \\
\text { facilities in } \\
\text { Connecticut, } \\
\text { in } \mathrm{lb} / \mathrm{mi}^{2} / \mathrm{yr}\end{array}$ & $\begin{array}{c}\text { Total nitrogen } \\
\text { yield } \\
\text { from } \\
\text { wastewater- } \\
\text { treatment } \\
\text { facilities } \\
\text { outside } \\
\text { Connecticut, } \\
\text { in lb/mi²/yr }\end{array}$ & $\begin{array}{c}\text { Annual } \\
\text { mean } \\
\text { runoff, } \\
\text { in inches }\end{array}$ \\
\hline \multicolumn{10}{|c|}{ B. Input data below for unmonitored sites/basins where predictions are necessary-Continued } \\
\hline Yantic & 2006 & 8.6 & 1 & 43.2 & 0.3 & 305,286 & 35,434 & 0 & 33.7 \\
\hline Yantic & 2007 & 8.6 & 1 & 43.2 & 0.3 & 249,528 & 28,962 & 0 & 31.3 \\
\hline Yantic & 2008 & 8.6 & 1 & 43.2 & 0.3 & 247,613 & 28,740 & 0 & 25.3 \\
\hline Yantic & 2009 & 8.6 & 1 & 43.2 & 0.3 & 234,070 & 27,168 & 0 & 31.0 \\
\hline Shetucket & 1999 & 11.5 & 1 & 31.1 & 1.2 & 0 & 0 & 0 & 22.5 \\
\hline Shetucket & 2000 & 11.5 & 1 & 31.1 & 1.2 & 0 & 0 & 0 & 24.3 \\
\hline Shetucket & 2001 & 11.5 & 1 & 31.1 & 1.2 & 0 & 0 & 0 & 21.2 \\
\hline Shetucket & 2002 & 11.5 & 1 & 31.1 & 1.2 & 0 & 0 & 0 & 11.1 \\
\hline Shetucket & 2003 & 11.5 & 1 & 31.1 & 1.2 & 0 & 0 & 0 & 28.4 \\
\hline Shetucket & 2004 & 11.5 & 1 & 31.1 & 1.2 & 0 & 0 & 0 & 30.0 \\
\hline Shetucket & 2005 & 11.5 & 1 & 31.1 & 1.2 & 0 & 0 & 0 & 27.8 \\
\hline Shetucket & 2006 & 11.5 & 1 & 31.1 & 1.2 & 0 & 0 & 0 & 42.7 \\
\hline Shetucket & 2007 & 11.5 & 1 & 31.1 & 1.2 & 0 & 0 & 0 & 30.9 \\
\hline Shetucket & 2008 & 11.5 & 1 & 31.1 & 1.2 & 0 & 0 & 0 & 26.5 \\
\hline Shetucket & 2009 & 11.5 & 1 & 31.1 & 1.2 & 0 & 0 & 0 & 31.0 \\
\hline Quinebaug & 1999 & 28.8 & 1 & 6.9 & 4.8 & 0 & 0 & 0 & 21.2 \\
\hline Quinebaug & 2000 & 28.8 & 1 & 6.9 & 4.8 & 0 & 0 & 0 & 22.3 \\
\hline Quinebaug & 2001 & 28.8 & 1 & 6.9 & 4.8 & 0 & 0 & 0 & 19.9 \\
\hline Quinebaug & 2002 & 28.8 & 1 & 6.9 & 4.8 & 0 & 0 & 0 & 11.0 \\
\hline Quinebaug & 2003 & 28.8 & 1 & 6.9 & 4.8 & 0 & 0 & 0 & 29.9 \\
\hline Quinebaug & 2004 & 28.8 & 1 & 6.9 & 4.8 & 0 & 0 & 0 & 23.9 \\
\hline Quinebaug & 2005 & 28.8 & 1 & 6.9 & 4.8 & 0 & 0 & 0 & 24.2 \\
\hline Quinebaug & 2006 & 28.8 & 1 & 6.9 & 4.8 & 0 & 0 & 0 & 29.2 \\
\hline Quinebaug & 2007 & 28.8 & 1 & 6.9 & 4.8 & 0 & 0 & 0 & 26.6 \\
\hline Quinebaug & 2008 & 28.8 & 1 & 6.9 & 4.8 & 0 & 0 & 0 & 22.7 \\
\hline Quinebaug & 2009 & 28.8 & 1 & 6.9 & 4.8 & 0 & 0 & 0 & 32.6 \\
\hline Pawcatuck & 1999 & 9.4 & 0 & 62.2 & 0.1 & 19,310 & 2,052 & 0 & 21.2 \\
\hline Pawcatuck & 2000 & 9.4 & 0 & 62.2 & 0.1 & 19,398 & 2,061 & 0 & 26.6 \\
\hline Pawcatuck & 2001 & 9.4 & 0 & 62.2 & 0.1 & 20,805 & 2,211 & 0 & 30.1 \\
\hline Pawcatuck & 2002 & 9.4 & 0 & 62.2 & 0.1 & 14,847 & 1,577 & 0 & 13.7 \\
\hline Pawcatuck & 2003 & 9.4 & 0 & 62.2 & 0.1 & 12,710 & 1,350 & 0 & 32.3 \\
\hline Pawcatuck & 2004 & 9.4 & 0 & 62.2 & 0.1 & 16,860 & 1,791 & 0 & 26.1 \\
\hline Pawcatuck & 2005 & 9.4 & 0 & 62.2 & 0.1 & 11,403 & 1,212 & 0 & 30.4 \\
\hline Pawcatuck & 2006 & 9.4 & 0 & 62.2 & 0.1 & 8,998 & 956 & 0 & 40.2 \\
\hline Pawcatuck & 2007 & 9.4 & 0 & 62.2 & 0.1 & 8,119 & 863 & 0 & 35.1 \\
\hline
\end{tabular}


Table 1-1. Load estimates and regression model input data.-Continued

[[Numbers are unrounded model inputs. Numbers in red are from Joseph Salata, U.S. Environmental Protection Agency, written commun., 2012. USGS, U.S. Geological Survey; ID, identification; $1 \mathrm{~b} / \mathrm{d}$, pounds per day; $\mathrm{lb} / \mathrm{yr}$, pounds per year; $\mathrm{lb} / \mathrm{mi}^{2} /$ year, pounds per square mile per year; $\mathrm{mi}^{2}$, square mile; S., south; N., north]

\begin{tabular}{|c|c|c|c|c|c|c|c|c|c|}
\hline $\begin{array}{c}\text { USGS } \\
\text { station ID } \\
\text { or name of } \\
\text { unmonitored } \\
\text { area } \\
\text { (figs. 1-2, } \\
\text { tables 1, 2) }\end{array}$ & $\begin{array}{l}\text { Water } \\
\text { year }\end{array}$ & $\begin{array}{c}\text { Drainage } \\
\text { area } \\
\left(\mathrm{mi}^{2}\right)\end{array}$ & $\begin{array}{l}\text { Long } \\
\text { Island } \\
\text { Sound } \\
\text { manage- } \\
\text { ment } \\
\text { zone } \\
\text { (fig. 12) }\end{array}$ & $\begin{array}{c}\text { Percentage } \\
\text { of } \\
\text { developed } \\
\text { land }\end{array}$ & $\begin{array}{c}\text { Percentage } \\
\text { of } \\
\text { cultivated } \\
\text { crops }\end{array}$ & $\begin{array}{c}\text { Total } \\
\text { nitrogen } \\
\text { load } \\
\text { from } \\
\text { wastewater- } \\
\text { treatment } \\
\text { facilities in } \\
\text { Connecticut, } \\
\text { in lb/yr }\end{array}$ & $\begin{array}{c}\text { Total } \\
\text { nitrogen yield } \\
\text { from } \\
\text { wastewater- } \\
\text { treatment } \\
\text { facilities in } \\
\text { Connecticut, } \\
\text { in lb/mi²/yr }\end{array}$ & $\begin{array}{c}\text { Total nitrogen } \\
\text { yield } \\
\text { from } \\
\text { wastewater- } \\
\text { treatment } \\
\text { facilities } \\
\text { outside } \\
\text { Connecticut, } \\
\text { in lb/mi²/yr }\end{array}$ & $\begin{array}{c}\text { Annual } \\
\text { mean } \\
\text { runoff, } \\
\text { in inches }\end{array}$ \\
\hline \multicolumn{10}{|c|}{ B. Input data below for unmonitored sites/basins where predictions are necessary-Continued } \\
\hline Pawcatuck & 2008 & 9.4 & 0 & 62.2 & 0.1 & 5,176 & 550 & 0 & 21.8 \\
\hline Pawcatuck & 2009 & 9.4 & 0 & 62.2 & 0.1 & 9,170 & 974 & 0 & 39.6 \\
\hline $\begin{array}{l}\text { Thames Main- } \\
\text { stem }\end{array}$ & 1999 & 107.7 & 1 & 22.8 & 0.4 & $1,715,474$ & 15,928 & 0 & 22.7 \\
\hline $\begin{array}{l}\text { Thames Main- } \\
\text { stem }\end{array}$ & 2000 & 107.7 & 1 & 22.8 & 0.4 & $1,618,820$ & 15,031 & 0 & 22.9 \\
\hline $\begin{array}{l}\text { Thames Main- } \\
\text { stem }\end{array}$ & 2001 & 107.7 & 1 & 22.8 & 0.4 & $1,251,883$ & 11,624 & 0 & 24.3 \\
\hline $\begin{array}{l}\text { Thames Main- } \\
\text { stem }\end{array}$ & 2002 & 107.7 & 1 & 22.8 & 0.4 & $1,022,262$ & 9,492 & 0 & 11.0 \\
\hline $\begin{array}{l}\text { Thames Main- } \\
\text { stem }\end{array}$ & 2003 & 107.7 & 1 & 22.8 & 0.4 & 980,178 & 9,101 & 0 & 31.2 \\
\hline $\begin{array}{l}\text { Thames Main- } \\
\text { stem }\end{array}$ & 2004 & 107.7 & 1 & 22.8 & 0.4 & $1,008,110$ & 9,360 & 0 & 27.0 \\
\hline $\begin{array}{l}\text { Thames Main- } \\
\text { stem }\end{array}$ & 2005 & 107.7 & 1 & 22.8 & 0.4 & 934,362 & 8,676 & 0 & 27.9 \\
\hline $\begin{array}{l}\text { Thames Main- } \\
\text { stem }\end{array}$ & 2006 & 107.7 & 1 & 22.8 & 0.4 & 919,015 & 8,533 & 0 & 33.7 \\
\hline $\begin{array}{l}\text { Thames Main- } \\
\text { stem }\end{array}$ & 2007 & 107.7 & 1 & 22.8 & 0.4 & 883,786 & 8,206 & 0 & 31.3 \\
\hline $\begin{array}{l}\text { Thames Main- } \\
\text { stem }\end{array}$ & 2008 & 107.7 & 1 & 22.8 & 0.4 & 690,457 & 6,411 & 0 & 25.3 \\
\hline $\begin{array}{l}\text { Thames Main- } \\
\text { stem }\end{array}$ & 2009 & 107.7 & 1 & 22.8 & 0.4 & 584,017 & 5,423 & 0 & 31.0 \\
\hline East of Thames & 1999 & 87.2 & 1 & 24.0 & 0.6 & 29,934 & 343 & 0 & 22.7 \\
\hline East of Thames & 2000 & 87.2 & 1 & 24.0 & 0.6 & 99,844 & 1,145 & 0 & 22.9 \\
\hline East of Thames & 2001 & 87.2 & 1 & 24.0 & 0.6 & 55,115 & 632 & 0 & 24.3 \\
\hline East of Thames & 2002 & 87.2 & 1 & 24.0 & 0.6 & 33,664 & 386 & 0 & 11.0 \\
\hline East of Thames & 2003 & 87.2 & 1 & 24.0 & 0.6 & 35,575 & 408 & 0 & 31.2 \\
\hline East of Thames & 2004 & 87.2 & 1 & 24.0 & 0.6 & 34,974 & 401 & 0 & 27.0 \\
\hline East of Thames & 2005 & 87.2 & 1 & 24.0 & 0.6 & 32,327 & 371 & 0 & 27.9 \\
\hline East of Thames & 2006 & 87.2 & 1 & 24.0 & 0.6 & 34,227 & 392 & 0 & 33.7 \\
\hline East of Thames & 2007 & 87.2 & 1 & 24.0 & 0.6 & 21,430 & 246 & 0 & 31.3 \\
\hline East of Thames & 2008 & 87.2 & 1 & 24.0 & 0.6 & 18,893 & 217 & 0 & 25.3 \\
\hline East of Thames & 2009 & 87.2 & 1 & 24.0 & 0.6 & 14,806 & 170 & 0 & 31.0 \\
\hline West of Thames & 1999 & 76.2 & 1 & 24.1 & 0.2 & 0 & 0 & 0 & 22.7 \\
\hline
\end{tabular}


Table 1-1. Load estimates and regression model input data.-Continued

[[Numbers are unrounded model inputs. Numbers in red are from Joseph Salata, U.S. Environmental Protection Agency, written commun., 2012. USGS, U.S. Geological Survey; ID, identification; lb/d, pounds per day; lb/yr, pounds per year; $1 \mathrm{~b} / \mathrm{mi}^{2} /$ year, pounds per square mile per year; $\mathrm{mi}^{2}$, square mile; S., south; N., north]

\begin{tabular}{|c|c|c|c|c|c|c|c|c|c|}
\hline $\begin{array}{c}\text { USGS } \\
\text { station ID } \\
\text { or name of } \\
\text { unmonitored } \\
\text { area } \\
\text { (figs. 1-2, } \\
\text { tables 1, 2) }\end{array}$ & $\begin{array}{c}\text { Water } \\
\text { year }\end{array}$ & $\begin{array}{l}\text { Drainage } \\
\text { area } \\
\left(\mathrm{mi}^{2}\right)\end{array}$ & $\begin{array}{l}\text { Long } \\
\text { Island } \\
\text { Sound } \\
\text { manage- } \\
\text { ment } \\
\text { zone } \\
\text { (fig. 12) }\end{array}$ & $\begin{array}{c}\text { Percentage } \\
\text { of } \\
\text { developed } \\
\text { land }\end{array}$ & $\begin{array}{l}\text { Percentage } \\
\text { of } \\
\text { cultivated } \\
\text { crops }\end{array}$ & $\begin{array}{c}\text { Total } \\
\text { nitrogen } \\
\text { load } \\
\text { from } \\
\text { wastewater- } \\
\text { treatment } \\
\text { facilities in } \\
\text { Connecticut, } \\
\text { in lb/yr }\end{array}$ & $\begin{array}{c}\text { Total } \\
\text { nitrogen yield } \\
\text { from } \\
\text { wastewater- } \\
\text { treatment } \\
\text { facilities in } \\
\text { Connecticut, } \\
\text { in } \mathrm{lb} / \mathrm{mi}^{2} / \mathrm{yr}\end{array}$ & $\begin{array}{c}\text { Total nitrogen } \\
\text { yield } \\
\text { from } \\
\text { wastewater- } \\
\text { treatment } \\
\text { facilities } \\
\text { outside } \\
\text { Connecticut, } \\
\text { in lb/mi²/yr }\end{array}$ & $\begin{array}{c}\text { Annual } \\
\text { mean } \\
\text { runoff, } \\
\text { in inches }\end{array}$ \\
\hline \multicolumn{10}{|c|}{ B. Input data below for unmonitored sites/basins where predictions are necessary-Continued } \\
\hline West of Thames & 2000 & 76.2 & 1 & 24.1 & 0.2 & 0 & 0 & 0 & 22.9 \\
\hline West of Thames & 2001 & 76.2 & 1 & 24.1 & 0.2 & 0 & 0 & 0 & 24.3 \\
\hline West of Thames & 2002 & 76.2 & 1 & 24.1 & 0.2 & 0 & 0 & 0 & 11.0 \\
\hline West of Thames & 2003 & 76.2 & 1 & 24.1 & 0.2 & 0 & 0 & 0 & 31.2 \\
\hline West of Thames & 2004 & 76.2 & 1 & 24.1 & 0.2 & 0 & 0 & 0 & 27.0 \\
\hline West of Thames & 2005 & 76.2 & 1 & 24.1 & 0.2 & 0 & 0 & 0 & 27.9 \\
\hline West of Thames & 2006 & 76.2 & 1 & 24.1 & 0.2 & 0 & 0 & 0 & 33.7 \\
\hline West of Thames & 2007 & 76.2 & 1 & 24.1 & 0.2 & 0 & 0 & 0 & 31.3 \\
\hline West of Thames & 2008 & 76.2 & 1 & 24.1 & 0.2 & 0 & 0 & 0 & 25.3 \\
\hline West of Thames & 2009 & 76.2 & 1 & 24.1 & 0.2 & 0 & 0 & 0 & 31.0 \\
\hline Central & 1999 & 210.6 & 3 & 23.6 & 0.4 & 370,849 & 1,761 & 0 & 15.8 \\
\hline Central & 2000 & 210.6 & 3 & 23.6 & 0.4 & 269,376 & 1,279 & 0 & 21.6 \\
\hline Central & 2001 & 210.6 & 3 & 23.6 & 0.4 & 199,655 & 948 & 0 & 24.7 \\
\hline Central & 2002 & 210.6 & 3 & 23.6 & 0.4 & 51,881 & 246 & 0 & 11.1 \\
\hline Central & 2003 & 210.6 & 3 & 23.6 & 0.4 & 29,623 & 141 & 0 & 28.5 \\
\hline Central & 2004 & 210.6 & 3 & 23.6 & 0.4 & 47,994 & 228 & 0 & 23.2 \\
\hline Central & 2005 & 210.6 & 3 & 23.6 & 0.4 & 40,563 & 193 & 0 & 22.2 \\
\hline Central & 2006 & 210.6 & 3 & 23.6 & 0.4 & 46,696 & 222 & 0 & 30.9 \\
\hline Central & 2007 & 210.6 & 3 & 23.6 & 0.4 & 41,237 & 196 & 0 & 28.7 \\
\hline Central & 2008 & 210.6 & 3 & 23.6 & 0.4 & 35,329 & 168 & 0 & 19.2 \\
\hline Central & 2009 & 210.6 & 3 & 23.6 & 0.4 & 34,785 & 165 & 0 & 25.5 \\
\hline Quinnipiac & 1999 & 54.7 & 3 & 54.7 & 1.3 & $1,031,863$ & 18,868 & 0 & 23.9 \\
\hline Quinnipiac & 2000 & 54.7 & 3 & 54.7 & 1.3 & $1,068,575$ & 19,539 & 0 & 27.3 \\
\hline Quinnipiac & 2001 & 54.7 & 3 & 54.7 & 1.3 & 810,413 & 14,819 & 0 & 24.9 \\
\hline Quinnipiac & 2002 & 54.7 & 3 & 54.7 & 1.3 & 685,392 & 12,533 & 0 & 12.5 \\
\hline Quinnipiac & 2003 & 54.7 & 3 & 54.7 & 1.3 & 686,256 & 12,548 & 0 & 32.8 \\
\hline Quinnipiac & 2004 & 54.7 & 3 & 54.7 & 1.3 & 762,028 & 13,934 & 0 & 31.0 \\
\hline Quinnipiac & 2005 & 54.7 & 3 & 54.7 & 1.3 & 750,163 & 13,717 & 0 & 27.8 \\
\hline Quinnipiac & 2006 & 54.7 & 3 & 54.7 & 1.3 & 615,095 & 11,247 & 0 & 47.0 \\
\hline Quinnipiac & 2007 & 54.7 & 3 & 54.7 & 1.3 & 505,355 & 9,241 & 0 & 33.8 \\
\hline Quinnipiac & 2008 & 54.7 & 3 & 54.7 & 1.3 & 408,424 & 7,468 & 0 & 26.8 \\
\hline Quinnipiac & 2009 & 54.7 & 3 & 54.7 & 1.3 & 343,400 & 6,279 & 0 & 31.5 \\
\hline West Central & 1999 & 130.5 & 3 & 54.0 & 0.1 & 924,714 & 7,084 & 0 & 22.0 \\
\hline West Central & 2000 & 130.5 & 3 & 54.0 & 0.1 & 936,594 & 7,175 & 0 & 29.6 \\
\hline
\end{tabular}


Table 1-1. Load estimates and regression model input data.-Continued

[[Numbers are unrounded model inputs. Numbers in red are from Joseph Salata, U.S. Environmental Protection Agency, written commun., 2012. USGS, U.S. Geological Survey; ID, identification; $1 \mathrm{~b} / \mathrm{d}$, pounds per day; $\mathrm{lb} / \mathrm{yr}$, pounds per year; $\mathrm{lb} / \mathrm{mi}^{2} /$ year, pounds per square mile per year; $\mathrm{mi}^{2}$, square mile; S., south; N., north]

\begin{tabular}{|c|c|c|c|c|c|c|c|c|c|}
\hline $\begin{array}{c}\text { USGS } \\
\text { station ID } \\
\text { or name of } \\
\text { unmonitored } \\
\text { area } \\
\text { (figs. 1-2, } \\
\text { tables 1,2) }\end{array}$ & $\begin{array}{c}\text { Water } \\
\text { year }\end{array}$ & $\begin{array}{l}\text { Drainage } \\
\text { area } \\
\left(\mathrm{mi}^{2}\right)\end{array}$ & $\begin{array}{l}\text { Long } \\
\text { Island } \\
\text { Sound } \\
\text { manage- } \\
\text { ment } \\
\text { zone } \\
\text { (fig. 12) }\end{array}$ & $\begin{array}{c}\text { Percentage } \\
\text { of } \\
\text { developed } \\
\text { land }\end{array}$ & $\begin{array}{l}\text { Percentage } \\
\text { of } \\
\text { cultivated } \\
\text { crops }\end{array}$ & $\begin{array}{c}\text { Total } \\
\text { nitrogen } \\
\text { load } \\
\text { from } \\
\text { wastewater- } \\
\text { treatment } \\
\text { facilities in } \\
\text { Connecticut, } \\
\text { in lb/yr }\end{array}$ & $\begin{array}{c}\text { Total } \\
\text { nitrogen yield } \\
\text { from } \\
\text { wastewater- } \\
\text { treatment } \\
\text { facilities in } \\
\text { Connecticut, } \\
\text { in } \mathrm{lb} / \mathrm{mi}^{2} / \mathrm{yr}\end{array}$ & $\begin{array}{c}\text { Total nitrogen } \\
\text { yield } \\
\text { from } \\
\text { wastewater- } \\
\text { treatment } \\
\text { facilities } \\
\text { outside } \\
\text { Connecticut, } \\
\text { in lb/mi²/yr }\end{array}$ & $\begin{array}{c}\text { Annual } \\
\text { mean } \\
\text { runoff, } \\
\text { in inches }\end{array}$ \\
\hline \multicolumn{10}{|c|}{ B. Input data below for unmonitored sites/basins where predictions are necessary-Continued } \\
\hline West Central & 2001 & 130.5 & 3 & 54.0 & 0.1 & 661,015 & 5,064 & 0 & 25.2 \\
\hline West Central & 2002 & 130.5 & 3 & 54.0 & 0.1 & 801,487 & 6,140 & 0 & 9.6 \\
\hline West Central & 2003 & 130.5 & 3 & 54.0 & 0.1 & 844,672 & 6,471 & 0 & 31.0 \\
\hline West Central & 2004 & 130.5 & 3 & 54.0 & 0.1 & 731,371 & 5,603 & 0 & 30.4 \\
\hline West Central & 2005 & 130.5 & 3 & 54.0 & 0.1 & 773,550 & 5,926 & 0 & 26.5 \\
\hline West Central & 2006 & 130.5 & 3 & 54.0 & 0.1 & 952,990 & 7,301 & 0 & 46.6 \\
\hline West Central & 2007 & 130.5 & 3 & 54.0 & 0.1 & $1,109,546$ & 8,500 & 0 & 32.2 \\
\hline West Central & 2008 & 130.5 & 3 & 54.0 & 0.1 & 885,219 & 6,781 & 0 & 25.8 \\
\hline West Central & 2009 & 130.5 & 3 & 54.0 & 0.1 & 769,759 & 5,897 & 0 & 28.3 \\
\hline Naugatuck & 1999 & 51.9 & 4 & 26.1 & 0.7 & 218,267 & 4,206 & 0 & 24.3 \\
\hline Naugatuck & 2000 & 51.9 & 4 & 26.1 & 0.7 & 190,320 & 3,667 & 0 & 27.8 \\
\hline Naugatuck & 2001 & 51.9 & 4 & 26.1 & 0.7 & 133,590 & 2,574 & 0 & 25.5 \\
\hline Naugatuck & 2002 & 51.9 & 4 & 26.1 & 0.7 & 134,622 & 2,594 & 0 & 14.2 \\
\hline Naugatuck & 2003 & 51.9 & 4 & 26.1 & 0.7 & 150,757 & 2,905 & 0 & 32.0 \\
\hline Naugatuck & 2004 & 51.9 & 4 & 26.1 & 0.7 & 136,628 & 2,633 & 0 & 31.6 \\
\hline Naugatuck & 2005 & 51.9 & 4 & 26.1 & 0.7 & 143,969 & 2,774 & 0 & 25.3 \\
\hline Naugatuck & 2006 & 51.9 & 4 & 26.1 & 0.7 & 137,508 & 2,650 & 0 & 45.2 \\
\hline Naugatuck & 2007 & 51.9 & 4 & 26.1 & 0.7 & 143,992 & 2,775 & 0 & 30.6 \\
\hline Naugatuck & 2008 & 51.9 & 4 & 26.1 & 0.7 & 124,043 & 2,390 & 0 & 30.5 \\
\hline Naugatuck & 2009 & 51.9 & 4 & 26.1 & 0.7 & 151,355 & 2,916 & 0 & 32.7 \\
\hline Saugatuck & 1999 & 68.8 & 5 & 22.6 & 0.1 & 35,470 & 516 & 0 & 24.9 \\
\hline Saugatuck & 2000 & 68.8 & 5 & 22.6 & 0.1 & 40,260 & 585 & 0 & 23.4 \\
\hline Saugatuck & 2001 & 68.8 & 5 & 22.6 & 0.1 & 43,800 & 637 & 0 & 19.8 \\
\hline Saugatuck & 2002 & 68.8 & 5 & 22.6 & 0.1 & 51,162 & 744 & 0 & 12.4 \\
\hline Saugatuck & 2003 & 68.8 & 5 & 22.6 & 0.1 & 54,675 & 795 & 0 & 29.8 \\
\hline Saugatuck & 2004 & 68.8 & 5 & 22.6 & 0.1 & 53,735 & 781 & 0 & 31.1 \\
\hline Saugatuck & 2005 & 68.8 & 5 & 22.6 & 0.1 & 50,508 & 734 & 0 & 24.9 \\
\hline Saugatuck & 2006 & 68.8 & 5 & 22.6 & 0.1 & 60,759 & 883 & 0 & 37.4 \\
\hline Saugatuck & 2007 & 68.8 & 5 & 22.6 & 0.1 & 30,587 & 445 & 0 & 29.8 \\
\hline Saugatuck & 2008 & 68.8 & 5 & 22.6 & 0.1 & 17,717 & 258 & 0 & 23.9 \\
\hline Saugatuck & 2009 & 68.8 & 5 & 22.6 & 0.1 & 12,474 & 181 & 0 & 25.0 \\
\hline Norwalk & 1999 & 29.6 & 5 & 42.0 & 0.1 & 441,056 & 14,916 & 0 & 21.1 \\
\hline
\end{tabular}


Table 1-1. Load estimates and regression model input data.-Continued

[[Numbers are unrounded model inputs. Numbers in red are from Joseph Salata, U.S. Environmental Protection Agency, written commun., 2012. USGS, U.S. Geological Survey; ID, identification; lb/d, pounds per day; lb/yr, pounds per year; $1 \mathrm{~b} / \mathrm{mi}^{2} /$ year, pounds per square mile per year; $\mathrm{mi}^{2}$, square mile; S., south; N., north]

\begin{tabular}{|c|c|c|c|c|c|c|c|c|c|}
\hline $\begin{array}{c}\text { USGS } \\
\text { station ID } \\
\text { or name of } \\
\text { unmonitored } \\
\text { area } \\
\text { (figs. 1-2, } \\
\text { tables 1,2) }\end{array}$ & $\begin{array}{l}\text { Water } \\
\text { year }\end{array}$ & $\begin{array}{c}\text { Drainage } \\
\text { area } \\
\left(\mathbf{m i}^{2}\right)\end{array}$ & $\begin{array}{c}\text { Long } \\
\text { Island } \\
\text { Sound } \\
\text { manage- } \\
\text { ment } \\
\text { zone } \\
\text { (fig. 12) }\end{array}$ & $\begin{array}{c}\text { Percentage } \\
\text { of } \\
\text { developed } \\
\text { land }\end{array}$ & $\begin{array}{c}\text { Percentage } \\
\text { of } \\
\text { cultivated } \\
\text { crops }\end{array}$ & $\begin{array}{c}\text { Total } \\
\text { nitrogen } \\
\text { load } \\
\text { from } \\
\text { wastewater- } \\
\text { treatment } \\
\text { facilities in } \\
\text { Connecticut, } \\
\text { in lb/yr }\end{array}$ & $\begin{array}{c}\text { Total } \\
\text { nitrogen yield } \\
\text { from } \\
\text { wastewater- } \\
\text { treatment } \\
\text { facilities in } \\
\text { Connecticut, } \\
\text { in } \mathrm{lb} / \mathrm{mi}^{2} / \mathrm{yr}\end{array}$ & $\begin{array}{c}\text { Total nitrogen } \\
\text { yield } \\
\text { from } \\
\text { wastewater- } \\
\text { treatment } \\
\text { facilities } \\
\text { outside } \\
\text { Connecticut, } \\
\text { in } \mathrm{lb} / \mathrm{mi}^{2} / \mathrm{yr}\end{array}$ & $\begin{array}{c}\text { Annual } \\
\text { mean } \\
\text { runoff, } \\
\text { in inches }\end{array}$ \\
\hline \multicolumn{10}{|c|}{ B. Input data below for unmonitored sites/basins where predictions are necessary-Continued } \\
\hline Norwalk & 2000 & 29.6 & 5 & 42.0 & 0.1 & 343,674 & 11,622 & 0 & 21.5 \\
\hline Norwalk & 2001 & 29.6 & 5 & 42.0 & 0.1 & 281,780 & 9,529 & 0 & 18.9 \\
\hline Norwalk & 2002 & 29.6 & 5 & 42.0 & 0.1 & 221,341 & 7,485 & 0 & 12.5 \\
\hline Norwalk & 2003 & 29.6 & 5 & 42.0 & 0.1 & 328,529 & 11,110 & 0 & 29.7 \\
\hline Norwalk & 2004 & 29.6 & 5 & 42.0 & 0.1 & 286,103 & 9,675 & 0 & 33.7 \\
\hline Norwalk & 2005 & 29.6 & 5 & 42.0 & 0.1 & 295,255 & 9,985 & 0 & 26.5 \\
\hline Norwalk & 2006 & 29.6 & 5 & 42.0 & 0.1 & 273,429 & 9,247 & 0 & 41.2 \\
\hline Norwalk & 2007 & 29.6 & 5 & 42.0 & 0.1 & 375,194 & 12,688 & 0 & 40.6 \\
\hline Norwalk & 2008 & 29.6 & 5 & 42.0 & 0.1 & 293,756 & 9,934 & 0 & 24.6 \\
\hline Norwalk & 2009 & 29.6 & 5 & 42.0 & 0.1 & 305,270 & 10,324 & 0 & 26.5 \\
\hline Southwest east & 1999 & 98.9 & 5 & 60.0 & 0.2 & $1,318,231$ & 13,327 & 0 & 15.3 \\
\hline Southwest east & 2000 & 98.9 & 5 & 60.0 & 0.2 & $1,269,288$ & 12,832 & 0 & 24.8 \\
\hline Southwest east & 2001 & 98.9 & 5 & 60.0 & 0.2 & $1,186,250$ & 11,993 & 0 & 23.3 \\
\hline Southwest east & 2002 & 98.9 & 5 & 60.0 & 0.2 & $1,317,763$ & 13,322 & 0 & 12.6 \\
\hline Southwest east & 2003 & 98.9 & 5 & 60.0 & 0.2 & $1,351,340$ & 13,662 & 0 & 32.3 \\
\hline Southwest east & 2004 & 98.9 & 5 & 60.0 & 0.2 & 752,064 & 7,603 & 0 & 30.0 \\
\hline Southwest east & 2005 & 98.9 & 5 & 60.0 & 0.2 & 820,486 & 8,295 & 0 & 21.3 \\
\hline Southwest east & 2006 & 98.9 & 5 & 60.0 & 0.2 & 837,010 & 8,462 & 0 & 41.1 \\
\hline Southwest east & 2007 & 98.9 & 5 & 60.0 & 0.2 & 637,832 & 6,448 & 0 & 33.2 \\
\hline Southwest east & 2008 & 98.9 & 5 & 60.0 & 0.2 & 726,274 & 7,342 & 0 & 21.0 \\
\hline Southwest east & 2009 & 98.9 & 5 & 60.0 & 0.2 & 654,479 & 6,617 & 0 & 23.8 \\
\hline Southwest west & 1999 & 167.1 & 6 & 44.6 & 0.1 & $1,069,654$ & 6,403 & 0 & 15.3 \\
\hline Southwest west & 2000 & 167.1 & 6 & 44.6 & 0.1 & $1,026,630$ & 6,145 & 0 & 24.8 \\
\hline Southwest west & 2001 & 167.1 & 6 & 44.6 & 0.1 & 940,605 & 5,631 & 0 & 23.3 \\
\hline Southwest west & 2002 & 167.1 & 6 & 44.6 & 0.1 & 759,744 & 4,548 & 0 & 12.6 \\
\hline Southwest west & 2003 & 167.1 & 6 & 44.6 & 0.1 & 782,554 & 4,684 & 0 & 32.3 \\
\hline Southwest west & 2004 & 167.1 & 6 & 44.6 & 0.1 & 710,015 & 4,250 & 0 & 30.0 \\
\hline Southwest west & 2005 & 167.1 & 6 & 44.6 & 0.1 & 757,259 & 4,533 & 0 & 21.3 \\
\hline Southwest west & 2006 & 167.1 & 6 & 44.6 & 0.1 & 639,492 & 3,828 & 0 & 41.1 \\
\hline Southwest west & 2007 & 167.1 & 6 & 44.6 & 0.1 & 527,700 & 3,159 & 0 & 33.2 \\
\hline Southwest west & 2008 & 167.1 & 6 & 44.6 & 0.1 & 417,994 & 2,502 & 0 & 21.0 \\
\hline Southwest west & 2009 & 167.1 & 6 & 44.6 & 0.1 & 356,695 & 2,135 & 0 & 23.8 \\
\hline
\end{tabular}


Table 2-1. Regression model yield estimates for unmonitored areas draining to Long Island Sound.

[Numbers are unrounded model output. Zero values indicate prediction estimate less than zero (negative number). USGS, U.S. Geological Survey; CT, Connecticut; ID, identifier; lbs/ $\mathrm{mi}^{2} /$ year, pounds per square mile per year; lbs/yr, pounds per year; N., north; S., south]

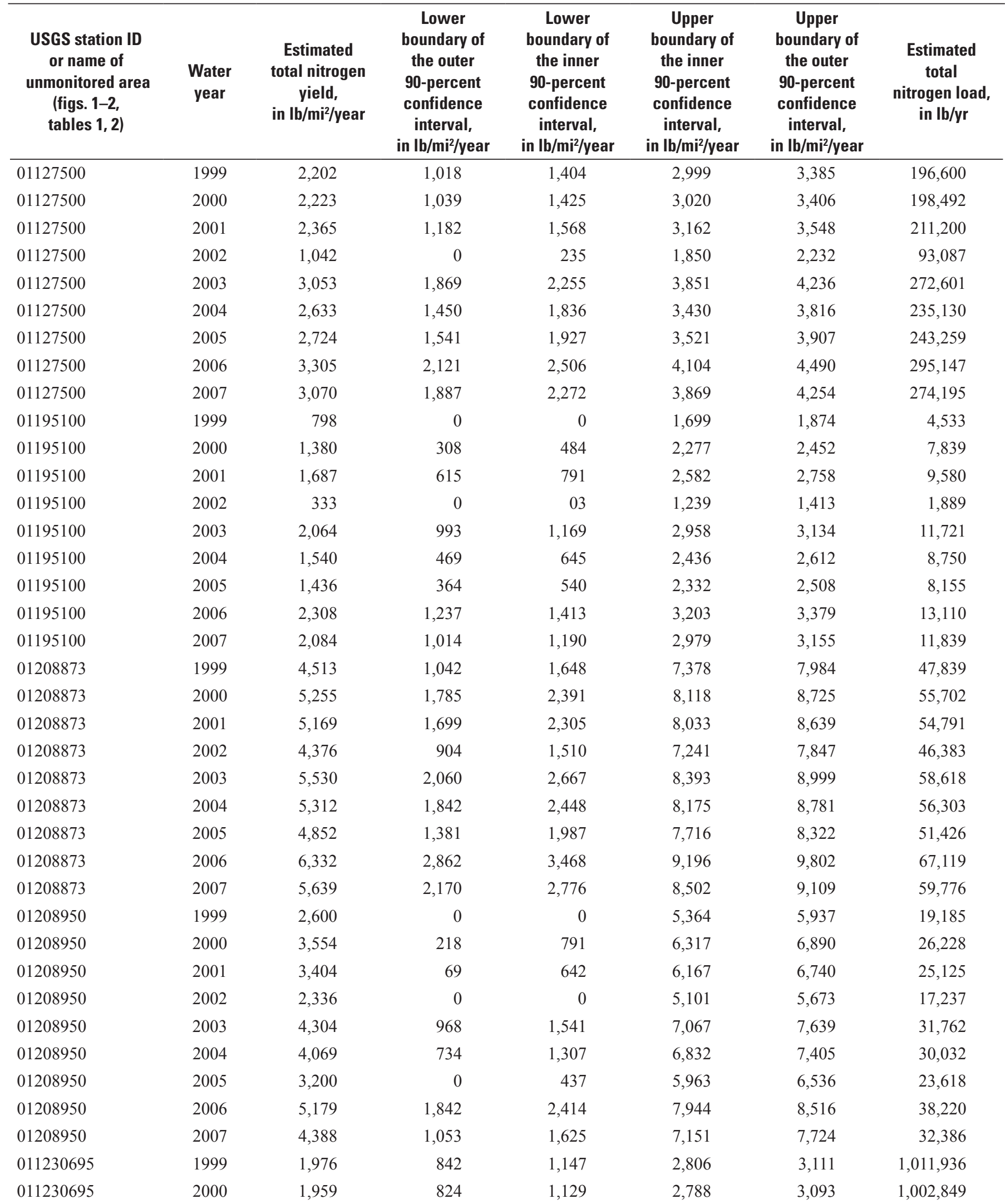


Table 2-1. Regression model yield estimates for unmonitored areas draining to Long Island Sound.—Continued

[Numbers are unrounded model output. Zero values indicate prediction estimate less than zero (negative number). USGS, U.S. Geological Survey; CT, Connecticut; ID, identifier; lbs/mi²/year, pounds per square mile per year; lbs/yr, pounds per year; N., north; S., south]

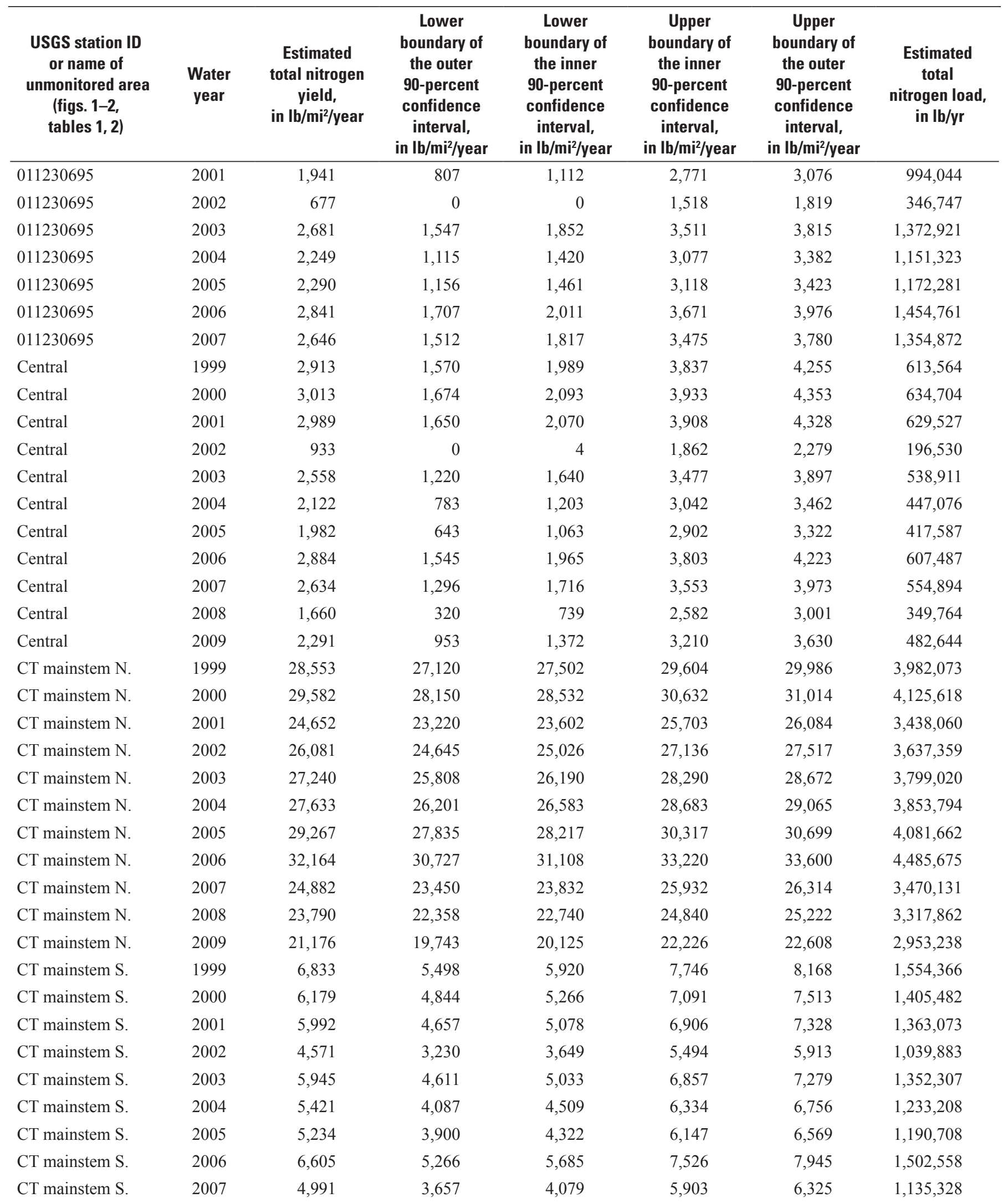


Table 2-1. Regression model yield estimates for unmonitored areas draining to Long Island Sound.—Continued

[Numbers are unrounded model output. Zero values indicate prediction estimate less than zero (negative number). USGS, U.S. Geological Survey; CT, Connecticut; ID, identifier; lbs/ $\mathrm{mi}^{2} /$ year, pounds per square mile per year; lbs/yr, pounds per year; N., north; S., south]

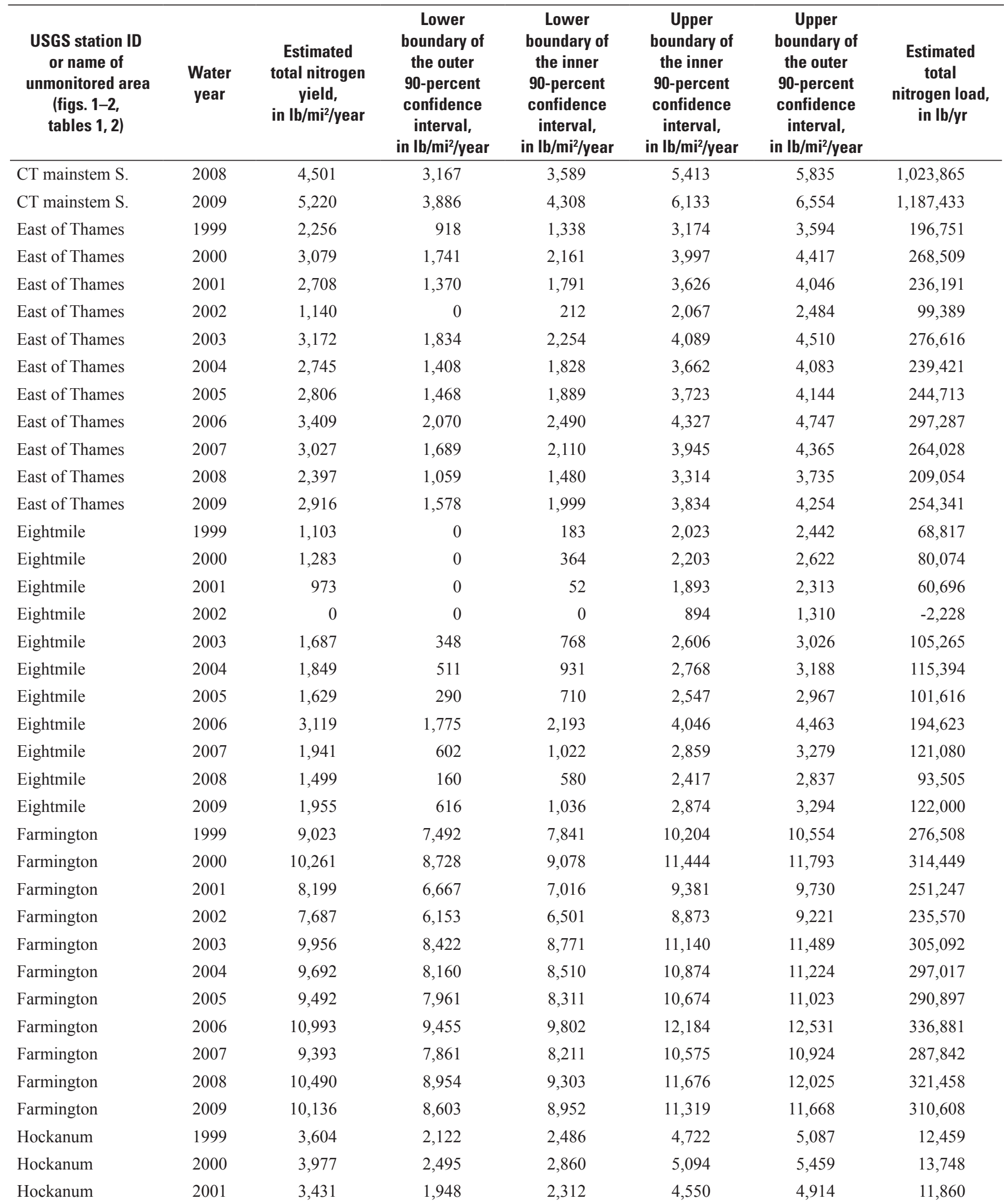


Table 2-1. Regression model yield estimates for unmonitored areas draining to Long Island Sound.—Continued

[Numbers are unrounded model output. Zero values indicate prediction estimate less than zero (negative number). USGS, U.S. Geological Survey; CT, Connecticut; ID, identifier; lbs/mi²/year, pounds per square mile per year; lbs/yr, pounds per year; N., north; S., south]

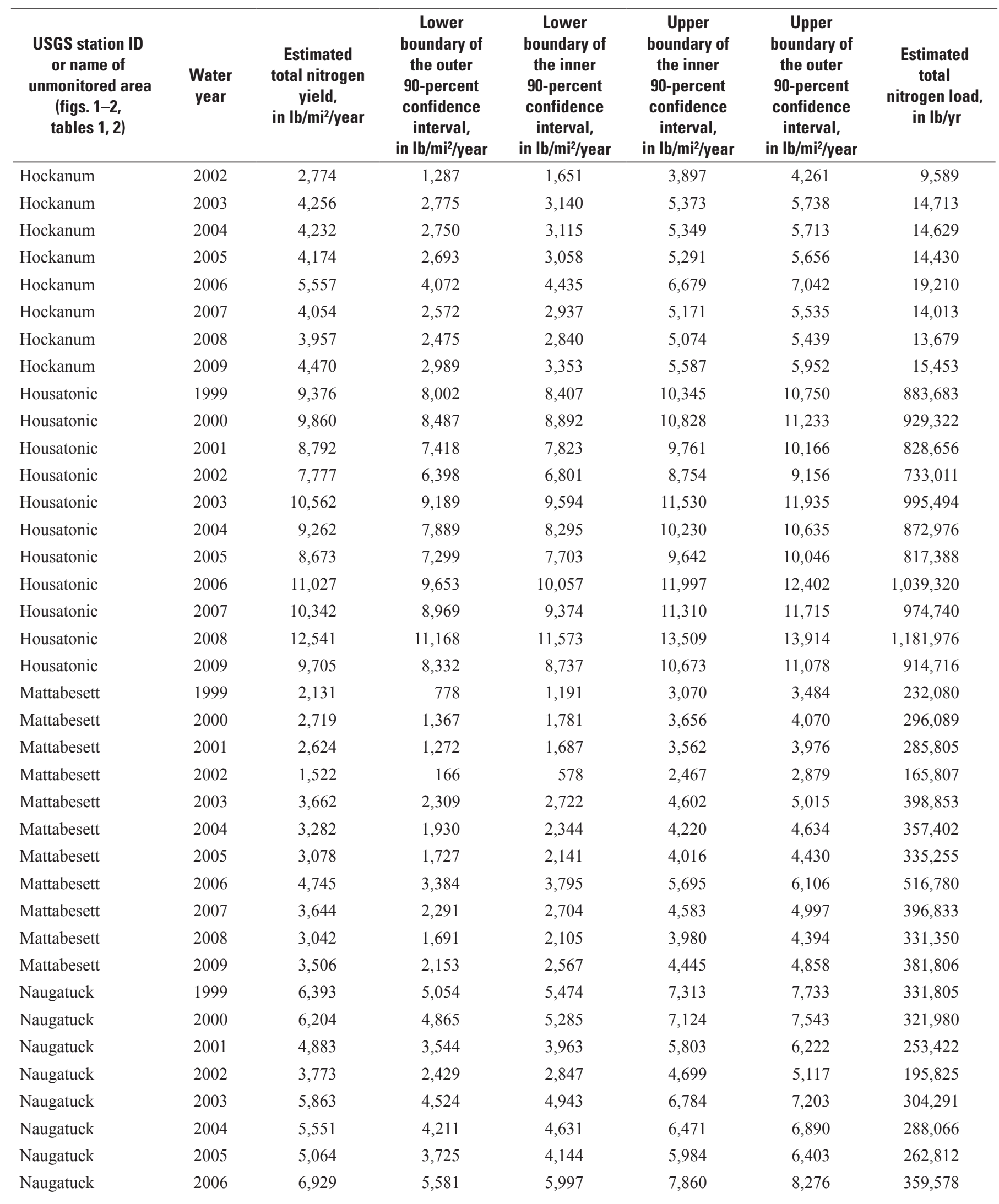


Table 2-1. Regression model yield estimates for unmonitored areas draining to Long Island Sound.-Continued

[Numbers are unrounded model output. Zero values indicate prediction estimate less than zero (negative number). USGS, U.S. Geological Survey; CT, Connecticut; ID, identifier; lbs/mi²/year, pounds per square mile per year; lbs/yr, pounds per year; N., north; S., south]

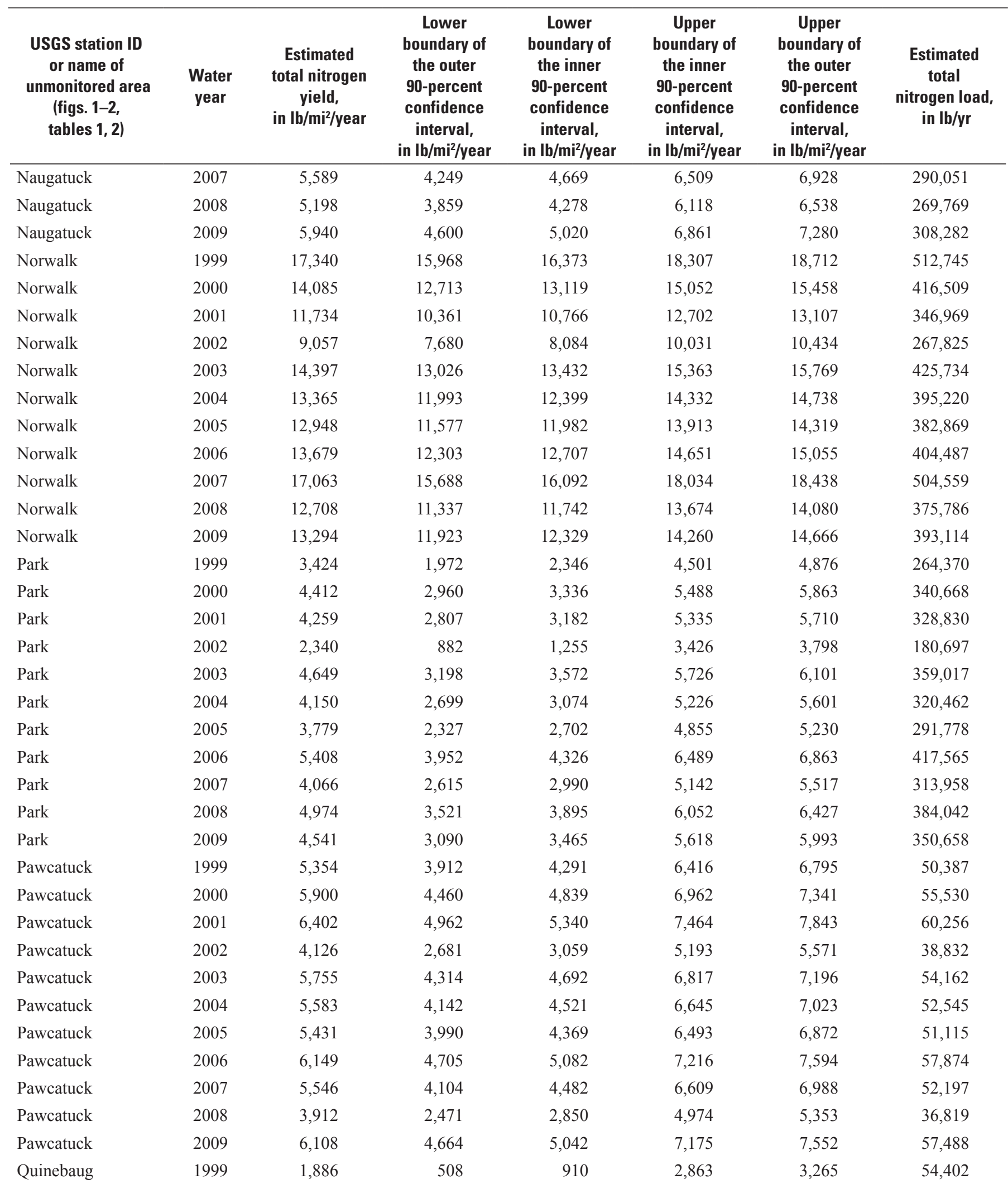


Table 2-1. Regression model yield estimates for unmonitored areas draining to Long Island Sound.-Continued

[Numbers are unrounded model output. Zero values indicate prediction estimate less than zero (negative number). USGS, U.S. Geological Survey; CT, Connecticut; ID, identifier; lbs/mi²/year, pounds per square mile per year; lbs/yr, pounds per year; N., north; S., south]

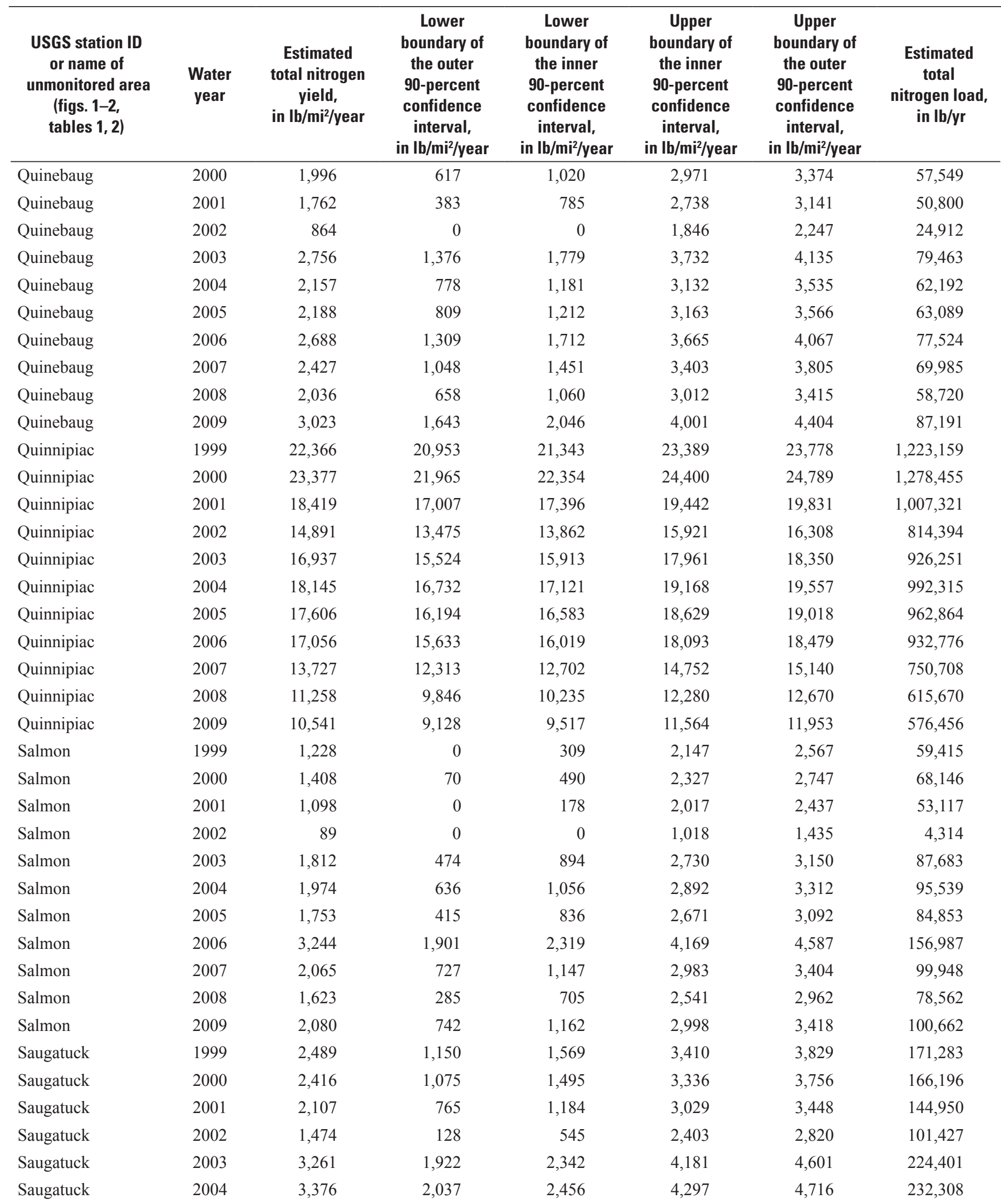


Table 2-1. Regression model yield estimates for unmonitored areas draining to Long Island Sound.—Continued

[Numbers are unrounded model output. Zero values indicate prediction estimate less than zero (negative number). USGS, U.S. Geological Survey; CT, Connecticut; ID, identifier; lbs/ $\mathrm{mi}^{2} /$ year, pounds per square mile per year; lbs/yr, pounds per year; N., north; S., south]

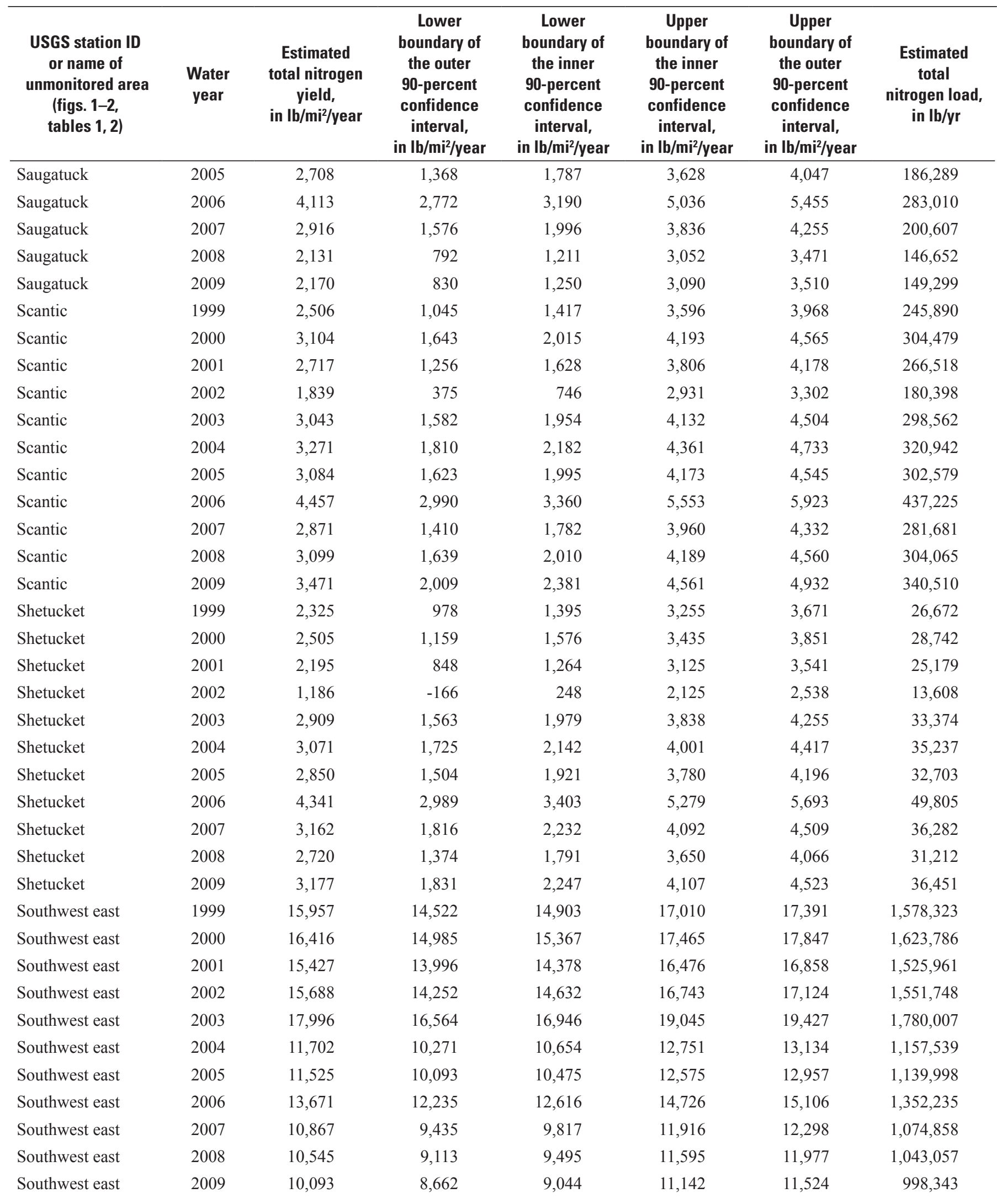


Table 2-1. Regression model yield estimates for unmonitored areas draining to Long Island Sound.-Continued

[Numbers are unrounded model output. Zero values indicate prediction estimate less than zero (negative number). USGS, U.S. Geological Survey; CT, Connecticut; ID, identifier; lbs/mi²/year, pounds per square mile per year; lbs/yr, pounds per year; N., north; S., south]

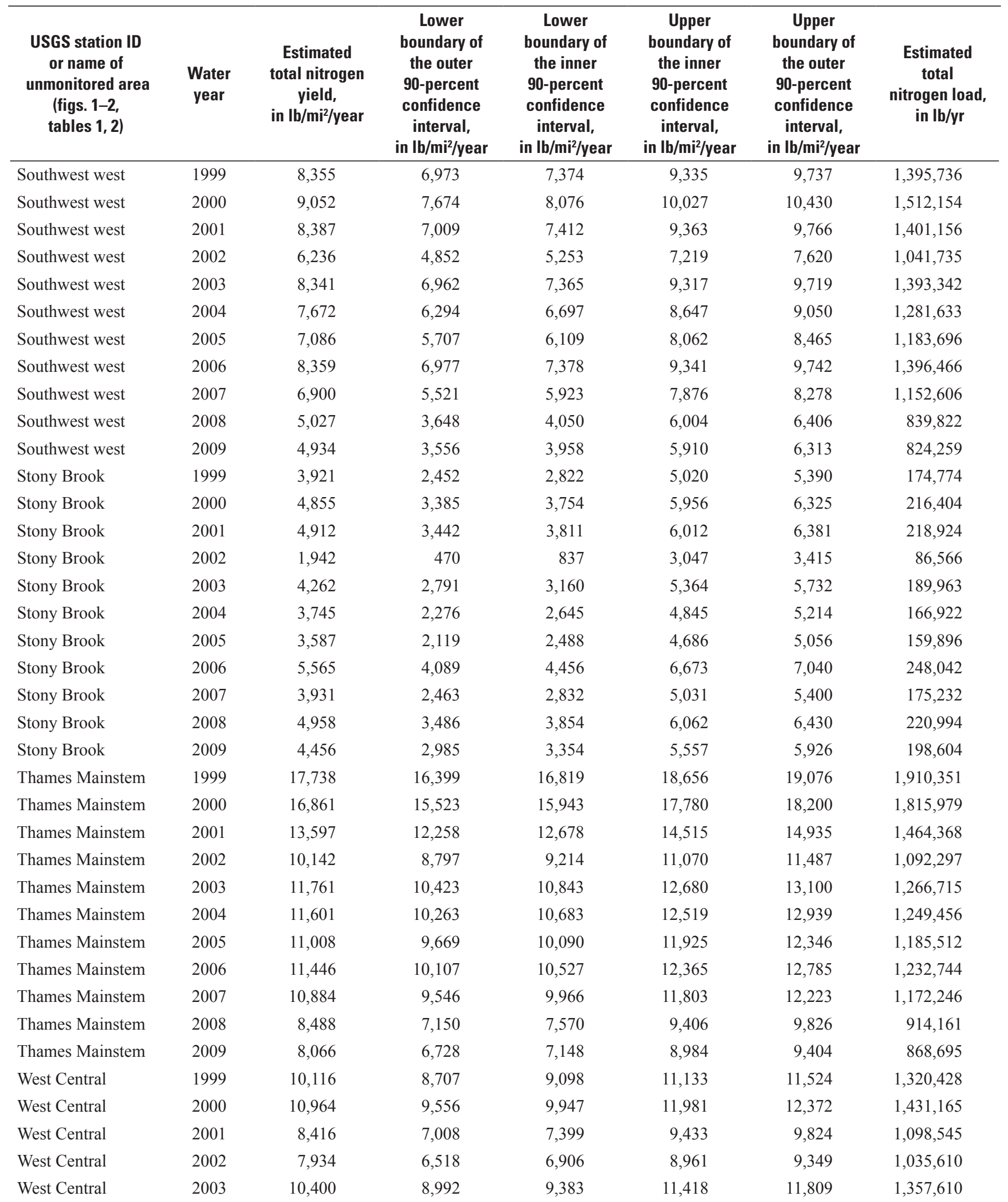


Table 2-1. Regression model yield estimates for unmonitored areas draining to Long Island Sound.-Continued

[Numbers are unrounded model output. Zero values indicate prediction estimate less than zero (negative number). USGS, U.S. Geological Survey; CT, Connecticut; ID, identifier; lbs/mi²/year, pounds per square mile per year; lbs/yr, pounds per year; N., north; S., south]

\begin{tabular}{|c|c|c|c|c|c|c|c|}
\hline $\begin{array}{l}\text { USGS station ID } \\
\text { or name of } \\
\text { unmonitored area } \\
\text { (figs. 1-2, } \\
\text { tables 1, 2) }\end{array}$ & $\begin{array}{c}\text { Water } \\
\text { year }\end{array}$ & $\begin{array}{c}\text { Estimated } \\
\text { total nitrogen } \\
\text { yield, } \\
\text { in } \mathrm{lb} / \mathrm{mi}^{2} / \text { year }\end{array}$ & $\begin{array}{c}\text { Lower } \\
\text { boundary of } \\
\text { the outer } \\
90 \text {-percent } \\
\text { confidence } \\
\text { interval, } \\
\text { in lb/mi²/year }\end{array}$ & $\begin{array}{c}\text { Lower } \\
\text { boundary of } \\
\text { the inner } \\
90 \text {-percent } \\
\text { confidence } \\
\text { interval, } \\
\text { in lb/mi²/year }\end{array}$ & $\begin{array}{c}\text { Upper } \\
\text { boundary of } \\
\text { the inner } \\
90 \text {-percent } \\
\text { confidence } \\
\text { interval, } \\
\text { in lb/mi2/year }\end{array}$ & $\begin{array}{c}\text { Upper } \\
\text { boundary of } \\
\text { the outer } \\
90 \text {-percent } \\
\text { confidence } \\
\text { interval, } \\
\text { in } \mathrm{lb} / \mathrm{mi}^{2} / \text { year }\end{array}$ & $\begin{array}{c}\text { Estimated } \\
\text { total } \\
\text { nitrogen load, } \\
\text { in lb/yr }\end{array}$ \\
\hline West Central & 2006 & 12,793 & 11,376 & 11,764 & 13,822 & 14,210 & $1,669,930$ \\
\hline West Central & 2007 & 12,556 & 11,148 & 11,538 & 13,574 & 13,965 & $1,639,025$ \\
\hline West Central & 2008 & 10,198 & 8,790 & 9,181 & 11,215 & 11,606 & $1,331,226$ \\
\hline West Central & 2009 & 9,564 & 8,156 & 8,547 & 10,581 & 10,972 & $1,248,482$ \\
\hline West of Thames & 2002 & 679 & -668 & -252 & 1,610 & 2,026 & 51,727 \\
\hline West of Thames & 2003 & 2,689 & 1,349 & 1,768 & 3,610 & 4,029 & 204,876 \\
\hline West of Thames & 2004 & 2,270 & 930 & 1,349 & 3,190 & 3,610 & 172,909 \\
\hline West of Thames & 2005 & 2,361 & 1,021 & 1,440 & 3,281 & 3,701 & 179,844 \\
\hline West of Thames & 2006 & 2,942 & 1,601 & 2,020 & 3,863 & 4,282 & 224,111 \\
\hline West of Thames & 2007 & 2,707 & 1,367 & 1,786 & 3,628 & 4,047 & 206,237 \\
\hline West of Thames & 2008 & 2,106 & 766 & 1,185 & 3,027 & 3,446 & 160,429 \\
\hline West of Thames & 2009 & 2,672 & 1,332 & 1,751 & 3,593 & 4,012 & 203,561 \\
\hline Yantic & 1999 & 38,075 & 36,701 & 37,106 & 39,044 & 39,448 & 328,041 \\
\hline Yantic & 2006 & 39,218 & 37,843 & 38,248 & 40,187 & 40,592 & 337,888 \\
\hline Yantic & 2007 & 32,511 & 31,138 & 31,543 & 33,480 & 33,885 & 280,109 \\
\hline Yantic & 2008 & 31,688 & 30,315 & 30,719 & 32,656 & 33,061 & 273,013 \\
\hline Yantic & 2009 & 30,682 & 29,309 & 29,713 & 31,651 & 32,055 & 264,348 \\
\hline
\end{tabular}




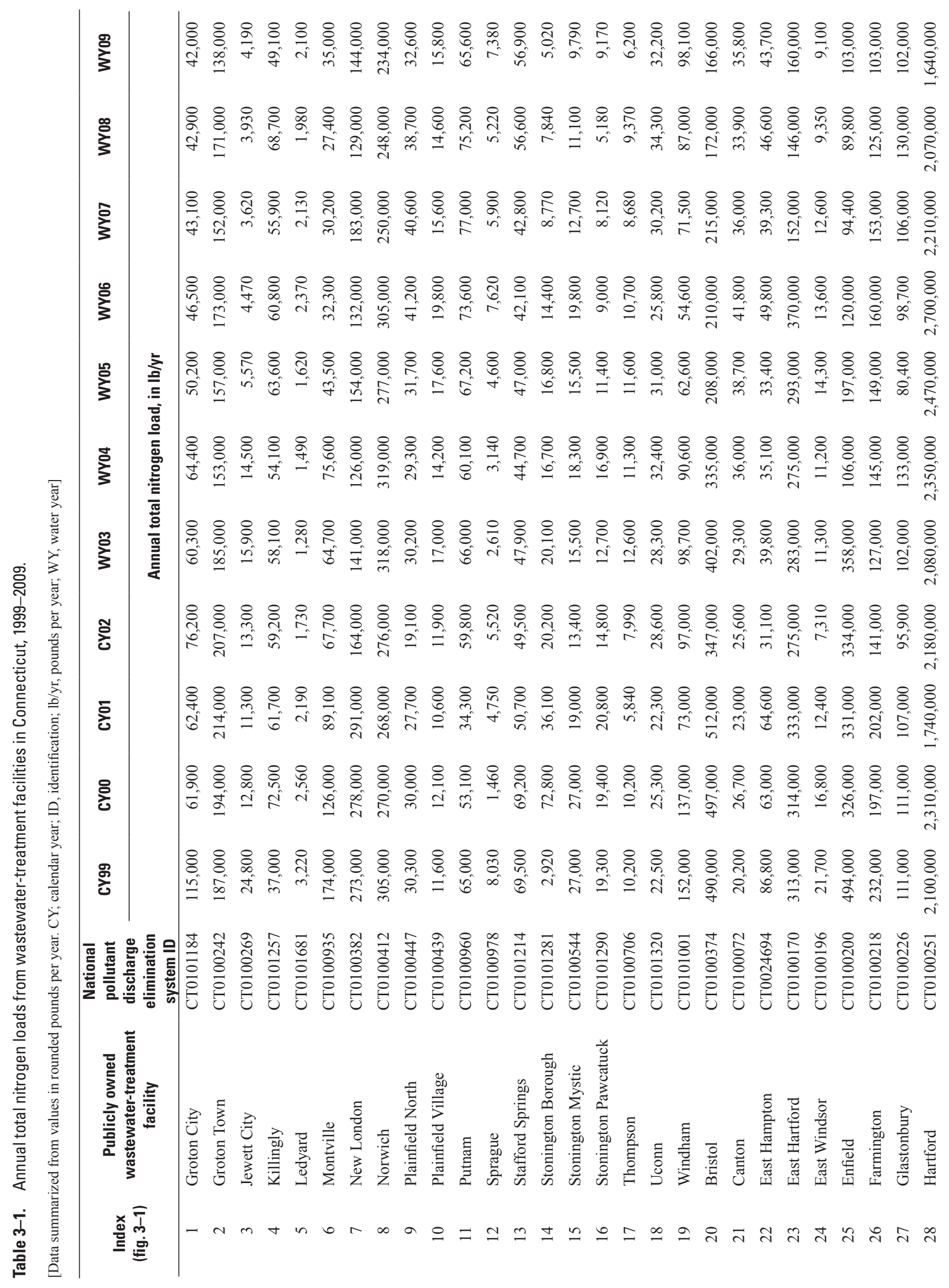




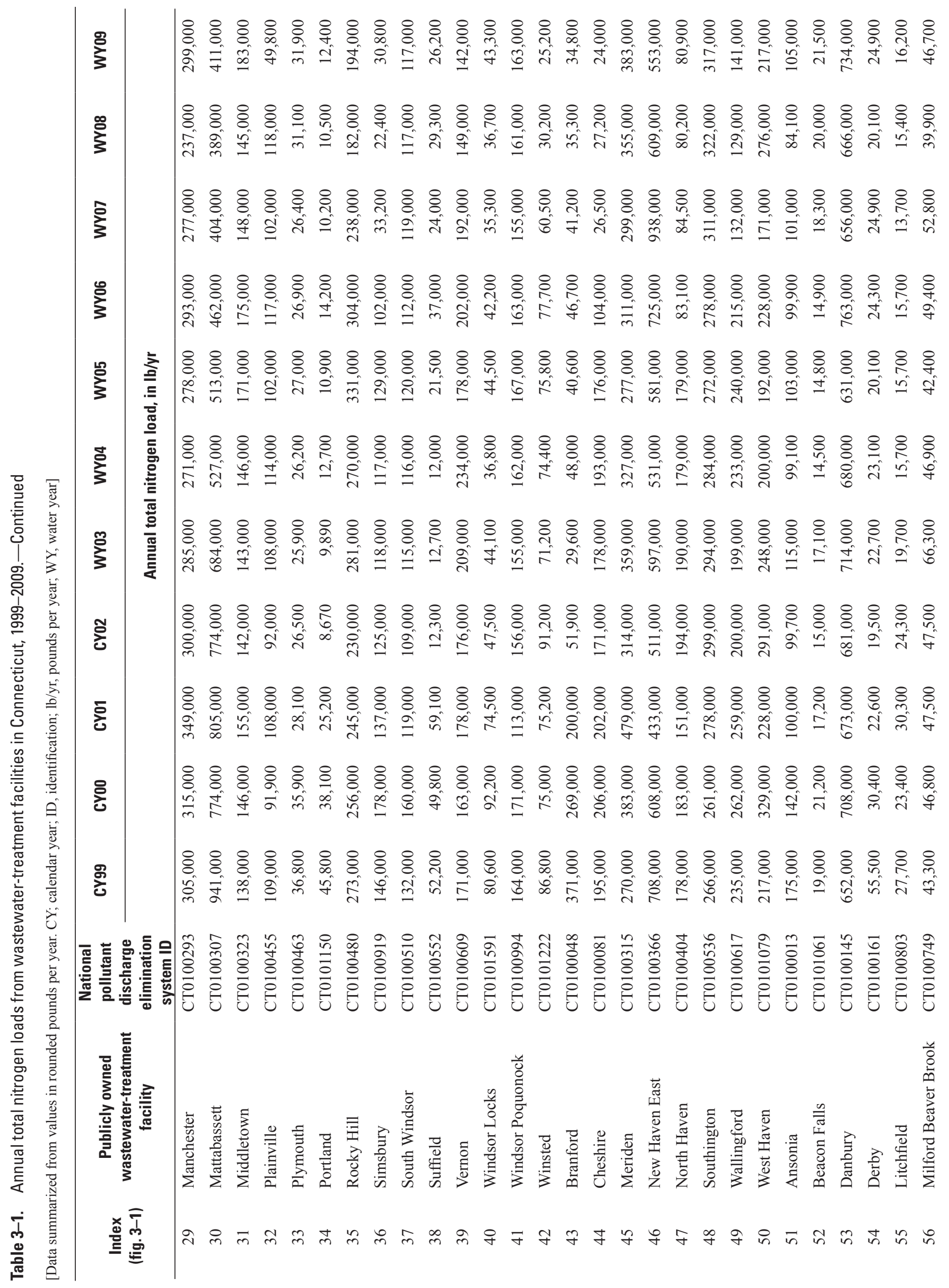




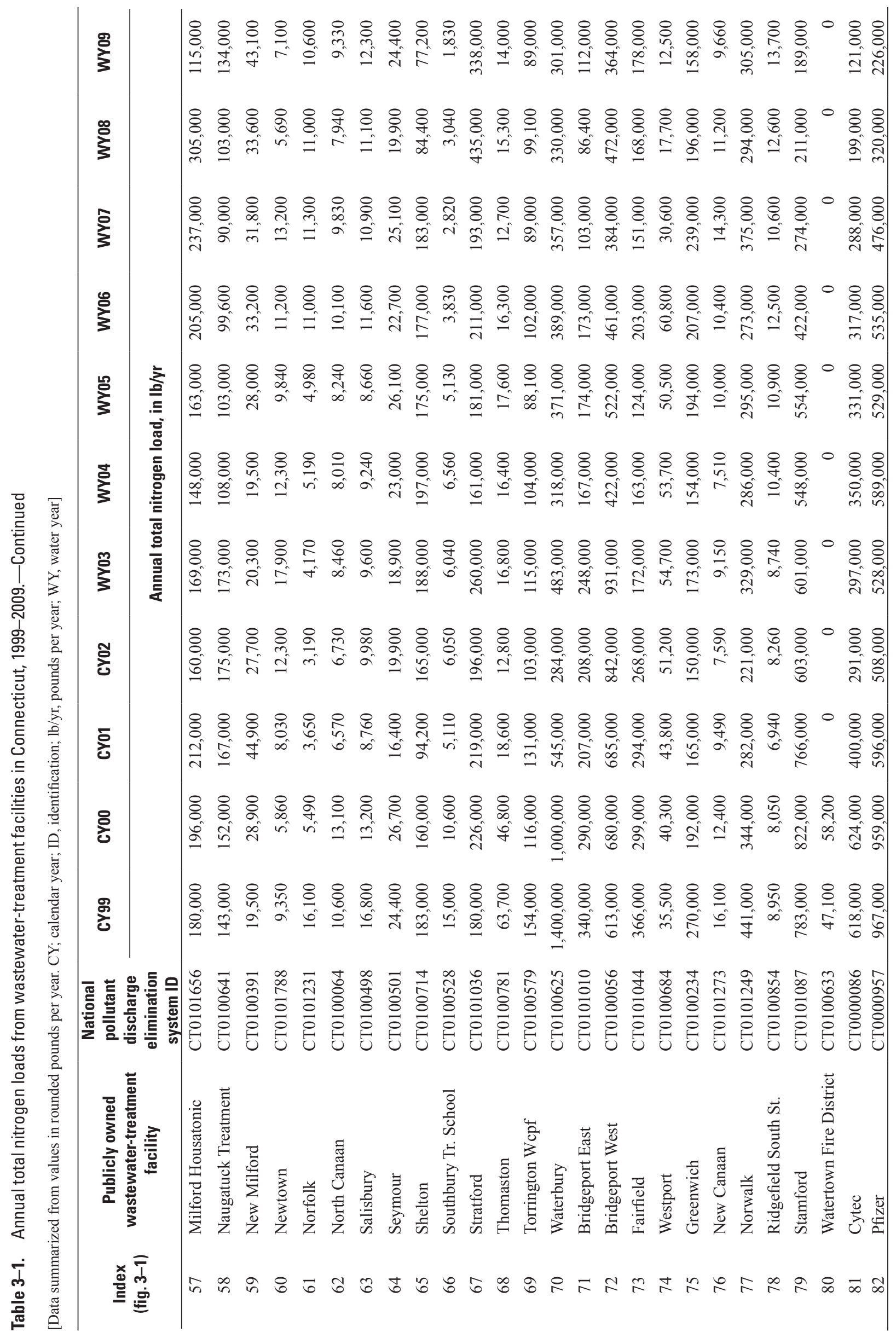




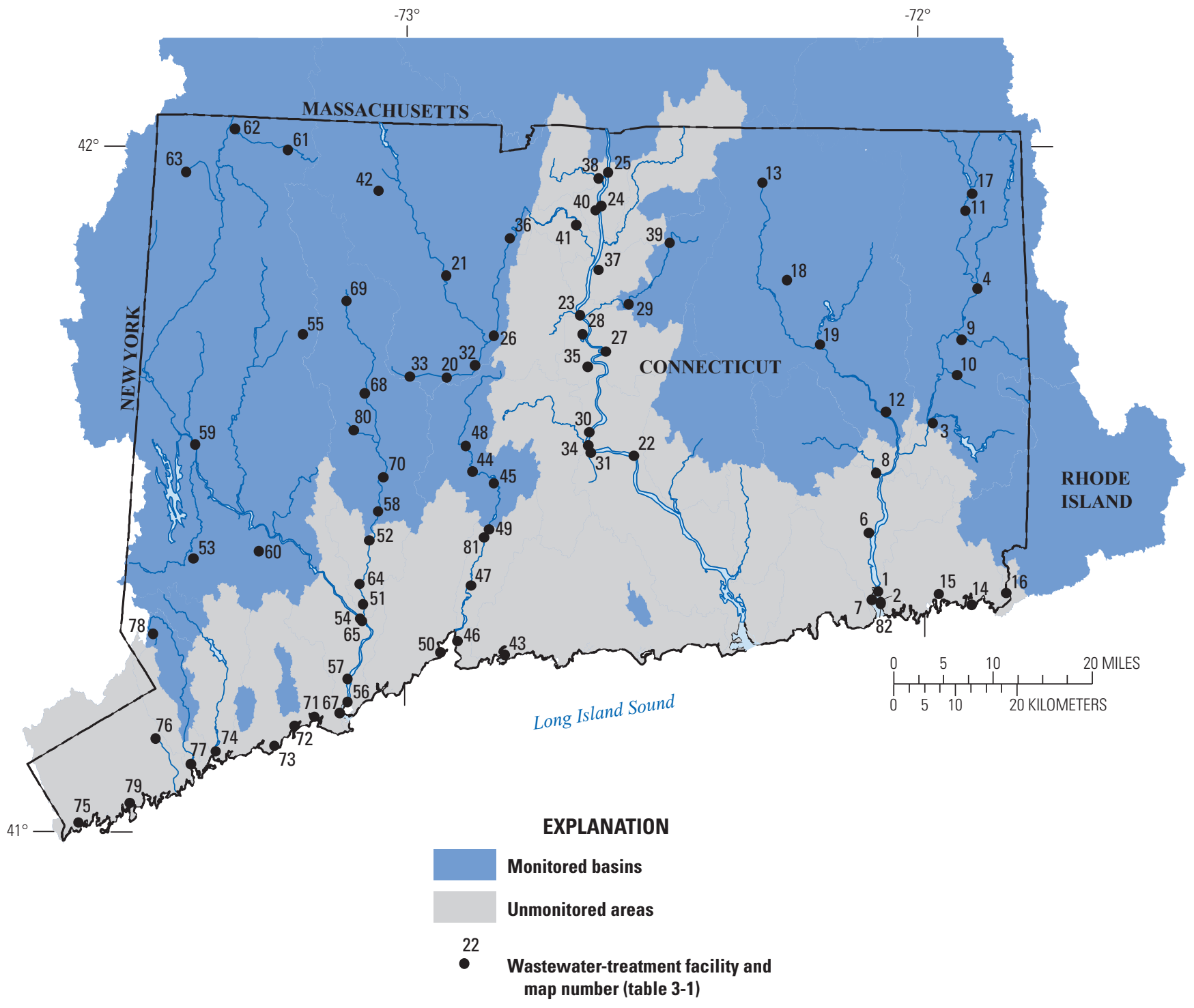

Figure 3-1. Map showing location of wastewater-treatment facilities in Connecticut. 
This page has been left blank intentionally. 
Prepared by the Pembroke Publishing Service Center.

For more information concerning this report, contact:

Chief

U.S. Geological Survey

New England Water Science Center

Connecticut Office

101 Pitkin Street

East Hartford, CT 06108

dc_ct@usgs.gov

or visit our Web site at:

http://ct.water.usgs.gov 
